\title{
THE EFFECT ON AIR AND WATER EMISSIONS OF ENERGY CONSERVATION IN INDUSTRY
}

\author{
PaUl D. Raskin and Richard A. Rosen
}

July 1977

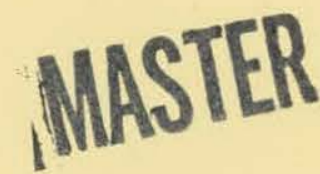

Prepared by the

ENERGY SYSTEMS RESEARCH GROUP, INC.

ALBANY, NEW YORK

For the

OFFICE OF ENVIRONMENTAL POLICY

NATIONAL CENTER FOR ANALYSIS OF ENERGY SYSTEMS

BROOKHAVEN NATIONAL LABORATORY ASSOCIATED UNIVERSITIES, INC.

UNDER CONTRACT NO, EY.76-C-02-0016 WITH THE

OFFICE OF TECHNOLOGY IMPACTS/ASEV

UNITED STATES DEPARTMENT OF ENERGY 


\section{DISCLAIMER}

This report was prepared as an account of work sponsored by an agency of the United States Government. Neither the United States Government nor any agency Thereof, nor any of their employees, makes any warranty, express or implied, or assumes any legal liability or responsibility for the accuracy, completeness, or usefulness of any information, apparatus, product, or process disclosed, or represents that its use would not infringe privately owned rights. Reference herein to any specific commercial product, process, or service by trade name, trademark, manufacturer, or otherwise does not necessarily constitute or imply its endorsement, recommendation, or favoring by the United States Government or any agency thereof. The views and opinions of authors expressed herein do not necessarily state or reflect those of the United States Government or any agency thereof. 


\section{DISCLAIMER}

Portions of this document may be illegible in electronic image products. Images are produced from the best available original document. 
BNL 50815

UC-95f

(Energy Conservation-Industry -

TID-4500)

\section{THE EFFECT ON AIR AND WATER EMISSIONS OF ENERGY CONSERVATION IN INDUSTRY}

Paul D. Raskin and Richard A. Rosen

This report was prepared as an account of work sponsored by the United States Government. Neither the United States nor the United States Department of Eneroy nor any of their employees, nor any of their congs chy warranty, express or implied, or assumes any legal in willy or expers

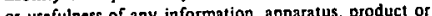

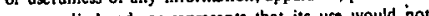
process disclosed, or represents that its use would hor

July 1977

Prepared by the

ENERGY SYSTEMS RESEARCH GROUP, INC.

ALBANY, NEW YORK

For the

OFFICE OF ENVIRONMENTAL POLICY

NATIONAL CENTER FOR ANALYSIS OF ENERGY SYSTEMS

BROOKHAVEN NATIONAL LABORATORY

UPTON, NEW YORK 11973 
NOTICE

This report was prepared as an account of work sponsored by the United States Government. Neither the United States nor the United States Department of Energy (DOE), nor any of their employees, nor any of their contractors, subcontractors, or their employees, makes any warranty, express or implied, or assumes any legal liability or responsibility for the accuracy, completeness or usefulness of any information, apparatus, product or process disclosed, or represents that its use would not infringe privately owned rights.

Printed in the United States of America

Available from

National Technical Information Service

U.S. Department of Commerce

5285 Port Royal Road

Springfield, VA 22161

Price: Printed Copy $\$ 6.00$; Microfiche $\$ 3.00$

May 1979

420 copies 
THIS PAGE

WAS INTENTIONALLY

LEFT BLANK 


\section{ABSTRACT}

Environmental emissions for five large energy consuming industries plus "others are estimated for four U.S. energy system scenarios for 1985 and 2000. Emissions are estimated by specifying fuel mixes to steam boilers and direct heat, combustion efficiencies, shifts in the relative shares of alternative industrial processes, use of industrial cogeneratores, and penetration of pollution control technologies. Analyses show that emissions do not vary significantly among scenarios principally because of increased coal use and the reduced penetration rate of advanced pollution control technologies in the low energy demand scenarios. Within scenarios, emissions from the chemical and iron and steel subsectors dominate all aggregate estimates. Hydrocarbon and carbon monoxide process emission coefficients for the chemical subsector must be improved. 


\section{THIS PAGE \\ WAS INTENTIONALLY \\ LEFT BLANK}


I. Introduction: . . . . . . . . . . . . . . . . . . 1

II. Industrial Energy Demand Implied by the Scenarios . . . . . . . 3 A. Material and/or Energy Demands by Industrial Category . . . . 4 B. Total Industrial Energy Constraints for the CONAES Scenarios. - 9

III. Industrial Conservation Targets: Technologies and Fuel Mix . . . 12. A. Meeting the Efficiency Targets: Technologies . . . . . . . 17

1. Cement. . . . . . . . . . . . . . . . 17

2. Paper .............................. 19

3. Aluminum. . . . . . . . . . . . . . . . 21

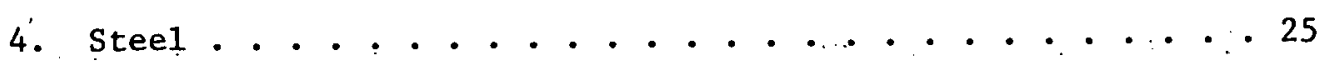

5. Chemicals ...................... 29

IV. Emission Coefficients by Industry . . . . . . . . . . . . 33

A. Steam Generation and Direct Heat. . ....... . . . . 34

B. Changes in Process Mix. . . . . . . . . . . . . . 36

C. Process Emissions . . . . . . . . . . . . . 37

D. Cogeneration. . . . . . . . . . . . . . 37

E. Pu1p and Paper. . . . . . . . . . . . . . . 4 40

F. Primary Aluminum. ................ . . 40

G. Iron and steel. . . . . . . . . . . . . . 45

H. Cement. . . . . . ............ 4 47

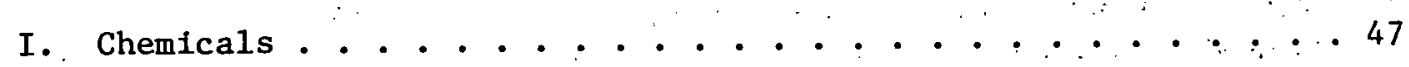

J. Emission Coefficients ..................... 49

v. Total Industrial Emissions. . . . ............... 51

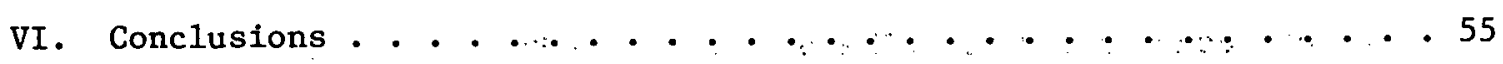

VII. References. . . . . . . . . . . . . . . . . 57

Appendix. Industrial Energy Flow Diagrams. . . . . . . . . . . 59 
1. Reference energy system, year 1985: SF-2. . . . . . . . . . 13

2. Reference energy system, year 2000: SF-2............. 14

3. Reference energy system, year 1985: NEP : . . . . . . . . . 15

4. Reference energy system, year 2000: NEP . . . . . . . . . . . 16

A-1: Paper industry R.E.S. extension, 1972. . . . . . . . . . . 60

A-2. Energy balance for steel industry, 1973. . . . . . . . . . . 61

A-3. Cement industry, 1973. . . . . . . . . . . . . . . . 62

A-4. Primary aluminum production, 1972. . . . . . . . . . . . 63

A-5. Revised R.E.S., petrochemicals and other chemicals, 1972 . . . . . 64

A-6. Revised R.E.S., cement, 1973 .................. . 64

A-7. Revised R.E.S., aluminum (primary), 1972 .............. 65

A-8. Revised R.E.S., paper, 1972.................... 65

A-9. Revised R.E.S., iron and steel ................. 66

\section{TABLES}

1. ERDA industrial demands and growth rates for 1972, 1985, and 2000. . . 5

2. Industrial energy consumption. . . . . . . . . . . . . 6

3. Derivation of CONAES material demands for 2000 and 1985. . . . . . . 8

4. Adjusted values of CONAES energy intensities . . . . . . . . . . 8

5. Energy resource distribution among end-use sectors for CONAES scenarios...................... 10

6. Total industry intermediate energy form mix, 2000. . . . . . . 10

7. Industrial fuel and electricity consumption. . . . . ....... . 11

8. Fuel mix constraints for CONAES $A$ and B, 2000. . . . . . . . . 11 


\section{TABLES (Continued)}

9. Efficiency improvements by 2000 from base year by scenario 1972. • . . 18

10. Fractional changes in energy use per unit of production by 2000 . . . 18

11. Cement: fuels to unit processes, 1972, 1985, and $2000 \ldots . . . . . .20$

12. Aggregate fuel mix per ton of cement . . . . . . . . . . . . . 20

13. Paper: fuels to unit processes, 1972, 1985, and 2000. . . . . . . 22

14. Aggregate fuel mix per ton of paper. . . . . . . . . . . . . 22

15. Primary aluminum: fuels to unit proceșses, 1972, 1985, and 2000 . . 24

16. Aggregate fuel mix per ton of aluminum . . . . . . . . . . . . 25

17. Steel process heat: fuels to unit processes, 1972, 1985, and 2000 . 27

18. Aggregate fuel mix per ton of steel. . . . . . . . . . . 28

19. Chemical and "other" process heat: fuels to unit processes, 1972, 1985, and 2000 . . . . . . . . . . . . . . . . . 31

20. Industry fuel mix summary, 1972, 1985, and 2000. . . . . . . . . 32

21. Pollutants . . . . . . . . . . . . . . . 33

22. Industrial boiler emission matrix, base-year and new plants. . . . . 35

23. New plant fraction of total production in five industrial sectors. . . 35

24. Cogeneration emission coefficients, gas turbine topping. . . . . . 38

25. Electric power plant emissions matrix. . . . . . . . . . . 38

26. Pulp and paper mill air emissions. . . . . . . . . . . . . 41

27. Water emission factors, pulp and paper . . . . . . . . . . . . 41

28. Pulp and paper mill emissions by scenario. . . . . . . . . . . . . 42

29. Primary aluminum unit process air emissions. . . . . . . . . . . 43

30. Primary aluminum plant emissions by scenario . . . . . . . . . . . . 44

31. Process emissions for iron and steel industry. . . . . . . . . . . 45

32. Iron and steel mill emissions by scenario. . . . . . . . . . . . 46 


\section{TABLES (Continued)}

33. Emission factors, cement. . . . . . . . . . . . 48

34. Summary emissions: cement. . . . . . . . . . . . . . 48

35. Chemical industry emissions by scenario . . . . . . . . . . . 50

36. Fractional breakdown, "other" industry. . . . . . . . . . . . . 52

37. Other industrial emissions. . . . . . . . . . . . . . . 52

38. Total industrial emissions by scenario A. . . . . . . . . . . . 53

39. Base-year total emissions used in three studies . . . . . . . . 56 


\section{INTRODUCTION}

The study described here was done to evaluate the environmental emissions in the industrial sectors of four selected energy system scenarios for two future years. It is a contribution to the assessment by the Brookhaven National Laboratory Office of Environmental Policy (OEP) of the national environmental implications of possible shifts toward conservation in energy utilization patterns. The four scenarios selected by OEP for analysis were CONAES* scenario A, CONAES scenario B, the National Energy Plan scenario, and ERDA scenario SF-2 (abbreviated, respectively, as $\mathrm{A}, \mathrm{B}, \mathrm{NEP}$, and $\mathrm{SF}-2$ ), and the years chosen were 1985 and 2000.

In Section II, explicit and implied scenario assumptions on industrial production and energy consumption are designated and broken down by major industrial categories. In Section III, resultant energy intensities (expressed in units of $10^{6} \mathrm{Btu} / \mathrm{short}$ ton) are translated into fuels to unit processes in each industry for nine cases: four scenarios, each in two future years, plus the base year (1972). The satisfaction of scenario-specific constraints on energy intensities and total industrial fuel mix allocations involves a number of changes from baseyear practices. The major variables used to meet scenario conservation requirements are (1) fuel mix to steam boilers and direct heat, (2) combustion efficiency improvements, (3) shifts in the relative shares of alternative processes, (4) phase-in rate of emerging process technologies, and (5) degree of penetration of industrial cogeneration with associated utility energy credit.

In Section IV, emission factors (in $1 b$ pollutant/short ton product) fcr an array of air and water pollutants are evaluated for five major energy-consuming industries for each scenario and year on the basis of the energy flows generated *CONAES = National Academy of Sciences Committee on Nuclear and Alternative Energy Strategies. 
in Section II. Emissions are consistently factored into contributions from direct combustion, processes, and cogeneration. To ensure reliable incorporation of the shifts in fuel mix, fractional process apportionment, and cogeneration utilization assumed in Section III, disaggregated emissions data are used. Also, anticipated intensification of the level of pollution-abatement technology in new facilities is weighted into the calculation of average emfssion factors. Thus, for each industry, base-year emission factors are broken down by process component; base-year plant and new-plant control levels are specified and phased in at scenario-implied growth rates; and averages are taken over the process mixes used in Section III to satisfy scenario constraints on energy efficiency. Additionally, cogeneration emissions and utilfty emission credits, spectfied by fuel input, are computed. Finally, total net emission factors for each industry are evaluatcd and summarized.

Next, the degree to which emissions are linear functions of total energy input is examined. At issue is whether emission coefficients (expressed as ratios of pollutant output to energy input) may be approximated as constants or are sensitively dependent on scenario assumptions. Possible sources of nonlinearities are differences in fuel mixes, in process mixes, in average emission control levels (which are dependent on assumed production growth rates since new plants are anticipated to have higher emission control levels), and in amounts and types of fuel to cogeneration and utility credit.

In Section $V$, total industrial pollutions are evaluated on the basis of the emission factor analysis of Section IV and the total material demands specified 
in Section II. In evaluating total emissions, estimates are derived also for industries other than the major ones selected for detailed treatment. . Finally, Section VI includes a brief discussion of the relationship of this work to other studies, the current limitations on further refinement, and possible directions for further exploration.

\section{INDUSTRIAL ENERGY DEMAND IMPLIED BY THE SCENARIOS}

Four scenarios for energy use for the years 1985 and 2000 were chosen for this study. Two are standard ERDA scenarios: SF-2 (a base case) and the Carter Administration's National Energy Plan (NEP, a mild conservation case); the other two are CONAES $A$ and $B$ (each with minimum purchased electricity). ${ }^{1}$ The ERDA scenarics postulate a real growth rate for gross national product (GNP) of about $3.1 \% / y r$, with a total energy resource consumption in the year 2000 of about 139 quads/yr (SF-2) or 120 quads/yr (NEP). ${ }^{2}$ In contrast, the CONAES scenarios, based on a real growth rate of $2 \% / y r$, represent moderate and strong conservation cases, with a total energy resource consumption in 2000 of 94 quads/yr (B) and 74 quads/yr (A).

These scenarios present severe problems in any attempt to arrive at an accurate picture of the industrial energy use implied by them, because they are all seriously underspecified, especially. the ERDA scenarios. This is especially true for this study because estimation of accurate environmental emission coefficients for the industrial sector requires knowledge of which industrial processes account for most of the energy used, since emissions are highly process dependent. Since much of this study is based on Rosen's work ${ }^{3}$ (in the BNL Economic Analysis Division) on industrial energy conservation, it treats the energy consumption in 
detail for the five major energy intensive industries that he considered: steel, paper, aluminum, cement, and (in a very aggregate way) chemicals (see Appendix). These five industries accounted for about two-thirds of industrial demand for intermediate energy forms (IEFs) in 1972. Thus, future aggregate fuel use and fuel mix can be derived if demands for the material output of these industries can be predicted and some assumptions are made about how the remainder of the industrial IEF requirement is used.

This section and the next first explain how the demands for each industrial category were derived from the information provided by ERDA and CONAES, and how the constraints on total industrial energy demand were calculated. Then the energy conservation targets for 2000 prescribed or implicit in each scenario are described and a reasonable set of conservation technologies for meeting those targets is elaborated. Finally, the fuel mix within each industrial category is calculated, and the aggregate fuel mix for each scenario for 1985 and 2000 is presented.

\section{A. Material and/or Energy Demands by Industrial Category}

The ERDA scenarios specify the exact number of tons of steel and primary aluminum to be produced by industry in both 1985 and 2000 . In this study it was assumed that the proportion of recycled scrap steel to total steel production remains at the 1972 value, and the manufacture of recycled aluminum into final products was relegated to the "Other" category. Growth rates for two of the other three major industries, paper and cement, were obtained by averaging the values derived by D. Behling ${ }^{2}$ for 1967-85 and 1985-2000 (see Table 1). Chemical feedstock requirements, with the fuel mix, are also specified by the ERDA scenarios. These include feedstocks for producing lubricants, waxes, asphalt, carbon black, etc.; 1.e., all final products of the petrochemical industry. 
Table 1

ERDA Industrial Demands and Growth Rates for 1972, 1985, and 2000

\begin{tabular}{|c|c|c|c|c|c|c|c|}
\hline & \multirow[b]{2}{*}{1972} & \multicolumn{2}{|c|}{$S F-2$} & \multirow{2}{*}{$\begin{array}{c}\% \text { Growth } \\
\text { rate } \\
1972-2000\end{array}$} & \multicolumn{2}{|c|}{ NEP } & \multirow{2}{*}{$\begin{array}{c}\% \text { Growth } \\
\text { rate } \\
1972-2000\end{array}$} \\
\hline & & 1985 & 2000 & & 1985 & 2000 & \\
\hline Steel ( $10^{6}$ tons) & 137 & 144 & 231 & 1.97 & 144 & 231 & 1.97 \\
\hline A1 ( $10^{6}$ tons) & 4.1 & 9.1 & 15.7 & 4.80 & 9.1 & 15.7 & 4.80 \\
\hline Cement ( $10^{6}$ tons) & 80 & 131 & 232 & $3.75 *$ & 131 & 232 & $3.7 \cdot 5 *$ \\
\hline Paper (10 $0^{6}$ lúus) & 59.5 & 92.5 & 154 & $3.40 *$ & 92.5 & 154 & $3.40 *$ \\
\hline Chem feedstocks (quads) & 4.19 & 5.66 & 10.66 & 3.33 & 6.25 & 11.65 & 3.65 \\
\hline
\end{tabular}

*Derived from ref. 5 .

Process heat requirements for the chemical industry as a whole in future years were simply scaled up* in proportion to feedstock demand and then adjusted downward by process heat efficiency improvements. Since the total fuel mix to industry is also specified by ERDA, the "Other" category was obtained by subtracting the results for the five major industries from the total. Except for the chemical industry, physical demands were assumed equal for the two ERDA scenarios.

For the CONAES scenarios, a quite different procedure had to be followed because the items specified ${ }^{1}$ include no tonnages of materials produced, only the total IEF energy consumptions expected for each industry in 2010, at some degree of efficiency improvement for CONAES B. To compute final demands, CONAES B with maximum purchased electricity was used rather than CONAES B with minimum purchased electricity and maximum cogeneration. The latter scenario incorporates much fuel for ' cogeneration, which is credited, i.e., subtracted, from total industry energy use (see Table 2). This case is interesting, but the energy consumption per ton of

*This linear scale-up provides only a rough approximation of chemical industry energy requirements; it may not necessarily be reasonable, but more detailed analyses were beyond the scope of this project. 


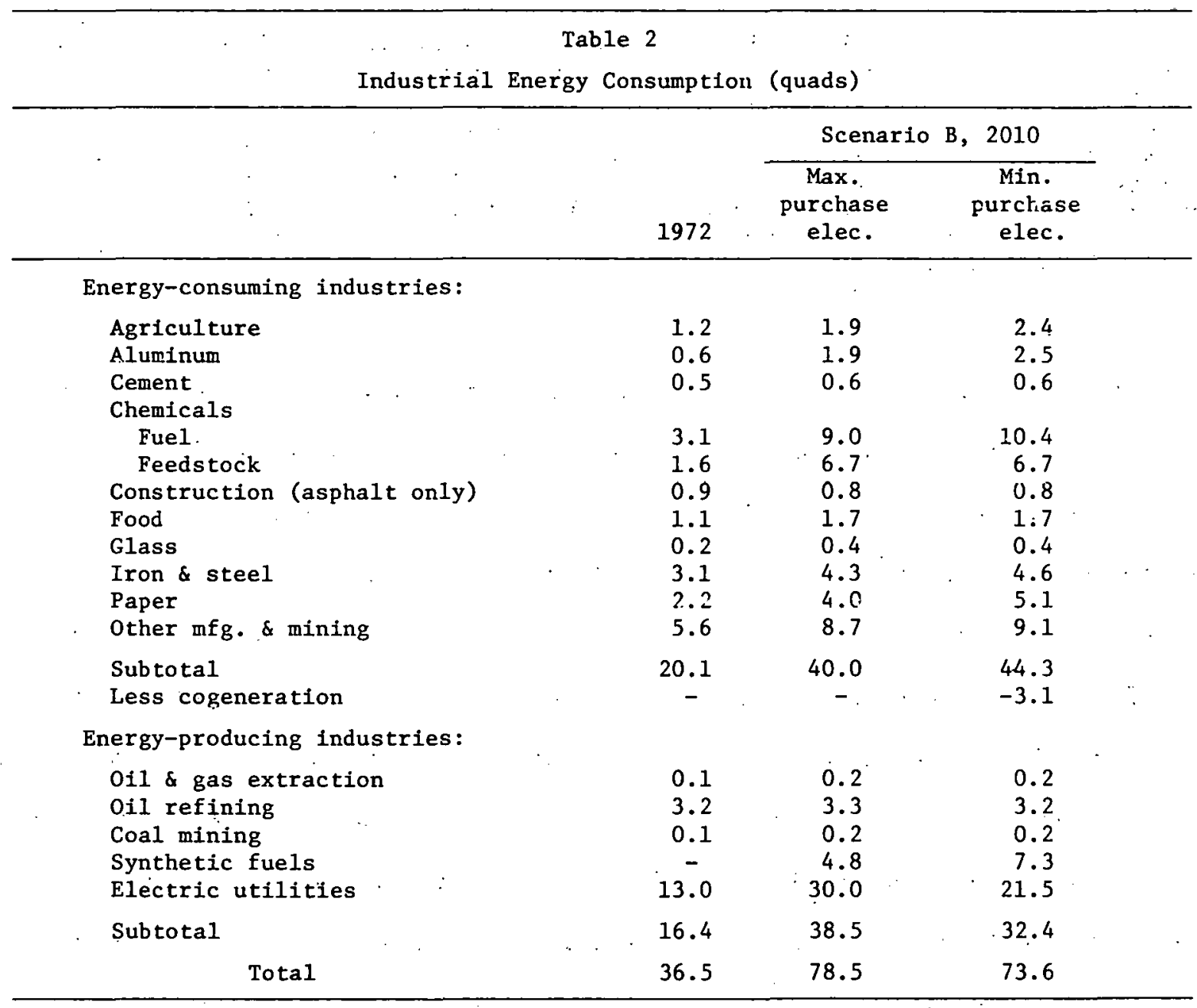


product and the fuel mix in CONAES $B$ with maximum purchased electricity were thought to reflect more closely those of 1972 , once the energy efficiency improvements (expressed as \% improvement) were deducted. Material tonnage demands were assumed to be the same for CONAES A and B since the real GNP growth rates given were the same, and chemical feedstock demands differed only slightly because of different degrees of energy efficiency improvement in the CONAES construction (asphalt) category (see Table 3). The growth rates, which are relative, could be derived from the absolute values of the energy required by each industry, proviided by CONAES.

To make the ERDA and CONAES scenarios comparablie, the energy values assigned by CONAES to each industry for 1972 had to be renormalized to the values used by ERDA. The adjusted values (Table 4) were obtained from the individual industry energy flow diagrams for the total in IEFs per ton of product, compiled by R. Rosen and shown in the Reference Energy Systems (RESs) in the Appendix. The corrected values for total energy use in steel, cement, and chemical process heat are very. close to the CONAES values for 1972.' That for aluminum differs, perhaps because it includes alumina refining. The corrected value for chemical feedstocks is so large because the RES-ERDA definition of feedstocks includes not only CONAES construction feedstocks (asphalt), but also lubes and waxes. The . greatest discrepancy is in the paper industry values, probably because CONAÉS. took account of the black liquor, bark, and wood consumed as fuel, whereas the corrected value is based only on the use of fossil fuels, which, in this study, is assumed to be the only use subject to energy resource limitations. The CONAES energy efficiency improvements for 2010 (column 3 of Table 3 ) were assumed to hold by 2000 . 
Table 3

Derivation of CONAES Naterial Demands for 2000 and 1985

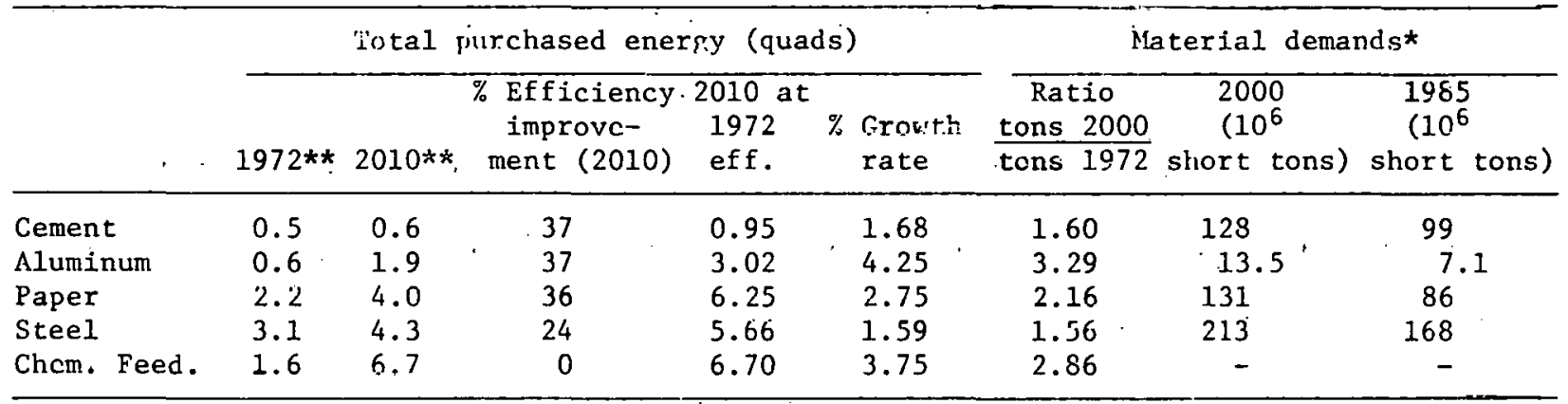

* See Table 1 for 1972 data.

**From ref. 1, Table II-2.

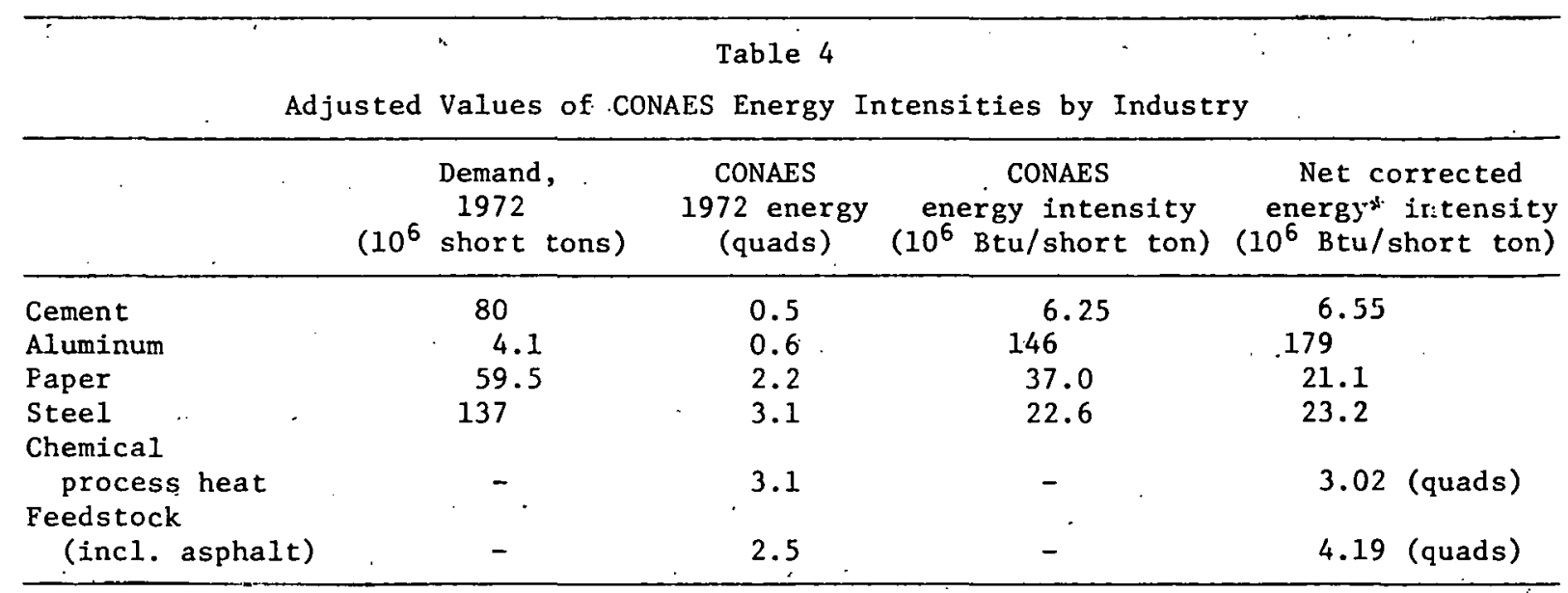

*These values are derived from ref. 3 and Appendix $A$, and are used for the rest of this study. 
B. Total Industrial Energy Constraints for the CONAES Scenarios

The total fuel mix for all of industry is specified by ERDA for its scenarios, but not by CONAES. In this study, for the year 2000, industry was assigned, for CONAES scenario A, 39.4 quads and, for B, 42.9 quads of fossil fuel resources (including any credits for the cogeneration of steam and electricity from the utility sector) (see Table 5). The CONAES levels of fuel use (Table 6) are inconsistent with these choices, but the percentages specified by CONAES for each fuel are almost identical for $A$ and $B$ and were therefore used in the calculations. Since CONAES specifies a heat rate for utilities of $11,500 \mathrm{Btu} / \mathrm{kW}-\mathrm{hr}$, this was assumed to be the heat rate from IEF to purchased electricity, including transmission losses, which implies that 3.37 units of energy are needed to make 1.0 unit of purchased electricity and therefore $2.37 \times 6.3 \%=14.9 \%$ more energy IEFs are needed for utility losses. From the data in Table 7 for scenario B with minimum electricity it was determined that electricity production was $\sim 35.5 \%$ nuclear, $49.3 \% \mathrm{coal}$, and $15.2 \%$ oil, and these values were assumed for 2000 . Dividing fuels to electricity in this fashion results in the following gross industrial IEF use: coal, $58.7 \%$; oil, $25.1 \%$; gas, $9.8 \%$; and nuclear, $6.4 \%$.

For CONAES B, industrial resources 1 osses would be $\sim 12.5 \%$ if they consisted simply of this sector's share of total losses in going from resources to IEF. However, since the industrial sector uses about twice as much, coal as other fossil fuels, and the coal loss in the ERDA RESs is $\sim 3.5 \%$, an averaged value of $-8 \%$ would be more accurate. Since utlity losses of IEFs are $14.9 / 1.149$ or 13\%, total resources remaining as IEFs would be $\sim 0.92$. $x 0.87=0.80$, i.e., $20 \% 1$ osses due to transport, mining, refining, utilities, etc. This leaves, of the assigned 39.4 and 42.9 quads, a net of 31.54 and 34.34 quads for IEFs to industry for CONAES A and B respectively. Application of the percentage breakdown for fuels 
Table 5

Energy Resource Distribution Among End-Use Sectors

for CONAES Scenarios (quads)

\begin{tabular}{clll}
\hline Scenario & \multicolumn{1}{c}{ Sector } & Energy resources for 2000 \\
\hline \multirow{2}{*}{ A } & Res.-com. & 22.6 (plus 0.8 solar) \\
& Transportation & 12.0 & \\
& Industry & 39.4 & \\
& Total* & 74.0 \\
& B & Res.-com. & 28.7 (plus 0.3 solar) \\
& Transportation & 16.0 & \\
& Industry & 42.9 & \\
& Total* & $87.6 * *$ & \\
\end{tabular}

*Includes sector share of utility and resource losses.

**Yields 94.0 in 2010 at a growth rate of $0.7 \% / y r$.

\begin{tabular}{lcc}
\hline \multicolumn{3}{c}{ Table 6} \\
Total Industry $\begin{array}{c}\text { Intermediate Energy Form } \\
\text { (from ref. 1, Table 8-2) }\end{array}$ & (IEF) Mix, 2000 \\
\hline \multicolumn{1}{c}{ IEF } & Quads (CONAES A) & $\%$ \\
\hline Coal & 15.98 & 57.0 \\
Oil & 7.15 & 25.4 \\
Gas & 3.20 & 11.3 \\
Purch. electricity & 1.76 & 6.3 \\
Total & 28.09 & 100.0 \\
\hline
\end{tabular}


Table 7

Industrial Fuel and Electricity Consumption (quads)

(from ref. 1 , Table $\mathrm{V}-6$ )

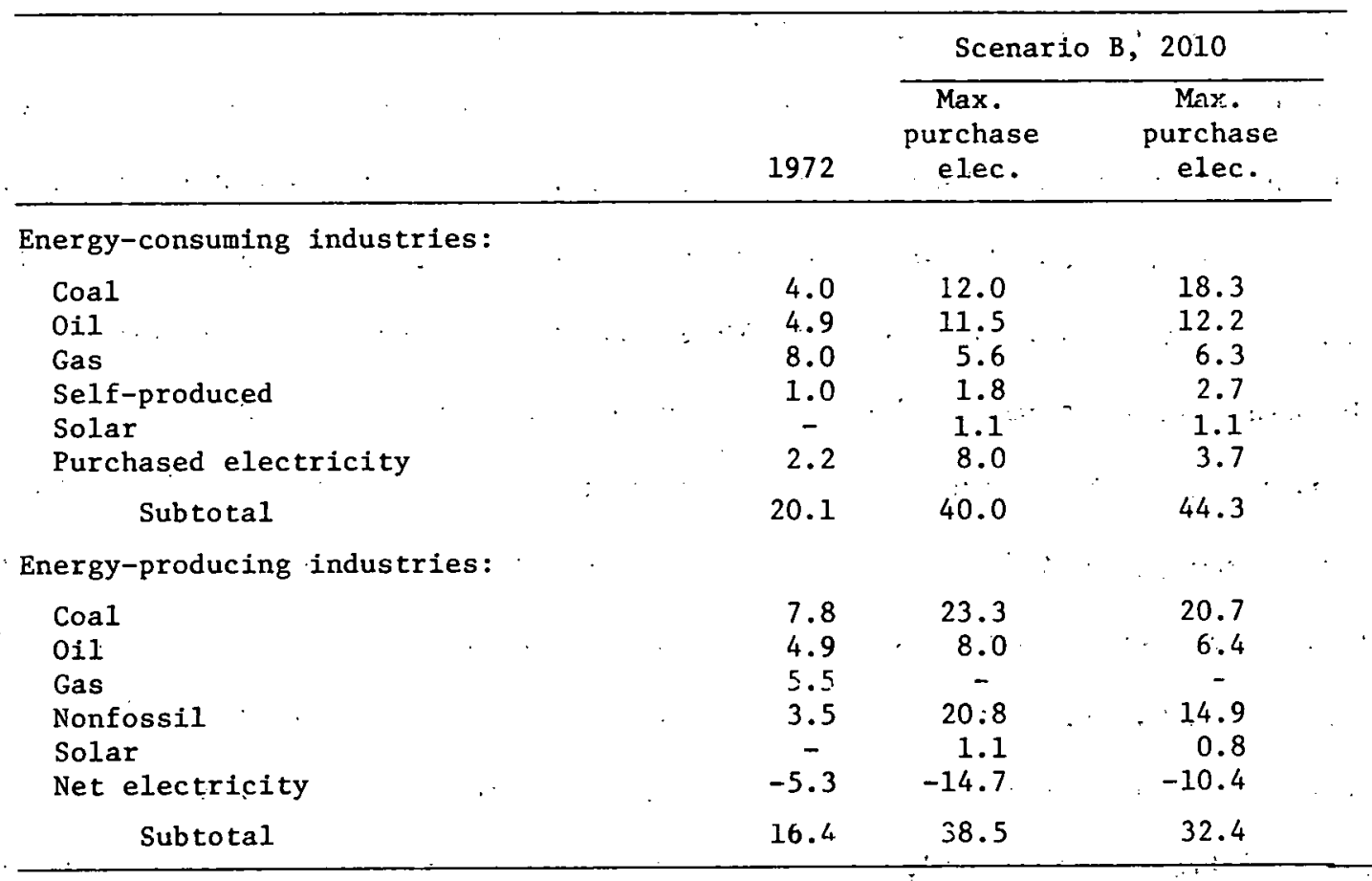

Table. 8

Fuel Mix Constraints for CONAES A and B, 2000 (quads)

\begin{tabular}{ccccccccc}
\hline Scenario & Coal & Oil & Gas. & $\begin{array}{l}\text { Purch. } \\
\text { elec. }\end{array}$ & $\begin{array}{l}\text { Total } \\
\text { IEFs }\end{array}$ & $\begin{array}{l}\text { Utility } \\
\text { losses }\end{array}$ & $\begin{array}{l}\text { Gross } \\
\text { total }\end{array}$ \\
\hline A & & 17.98 & 8.01 & 3.55 & 1.99 & 31.54 & 4.71 & 36.25 \\
B & 19.58 & 8.72 & 3.87 & 2.17 & 34.34 & $5: 13$ & 39.47 \\
\hline
\end{tabular}


derived above results in the fuel $\mathrm{mix}$ listed in Table 8 as constraints on industry energy use in 2000 for this study.

III. INDUSTRIAL CONSERVATION TARGETS: TECHNOLOGIES AND FUEL MIX

The constraints on energy efficiency improvements are specified in quite different ways in the ERDA and the CONAES scenarios.

The ERDA scenarios provide directly two efficiencies: one for electricity consumption in aluminum electrolytic cells and one for coal consumption in blast furnaces and ccke ovens taken together (see Figures 1 to 4 ). For SF-2 these two efficiencies remain constant between 1972 and 2000, showing no improvement. For NEP the blast furnace plus coke oven efficiency increases from 0.24 to 0.27 , an $11 \%$ improvement. Even though much of the energy used by the steel industry is not in this category, in this study, for the NEP scenario, an overall $11 \%$ efficiency improvement by 2000 was assumed for the steel industry except for the electric drive efficiency, which was kept constant. Similarly, for NEP the efficiency of electricity use in the aluminum industry changes from 0.57 in 1972 to 0.74 in 2000, a 23\% improvement, and, for this study, this level of improvement was extended to cover all process energy use in the aluminum industry. Since all other industries are aggregated into the "process heat and misc." line in the RES, the efficiency of process energy use for the cement, paper, and chemical industries was improved, in this study, by the indicated amounts, i.e., $9 \%$ for $\mathrm{SF}-2$ and $12.5 \%$ for NEP by 2000. Chemical feedstocks are given and were not modified.

The CONAES study provided an energy efficiency target for each industry. These targets were interpreted for this study as applicable to the net purchased energy used by the industry, after allowing the industry a credit (due to the 


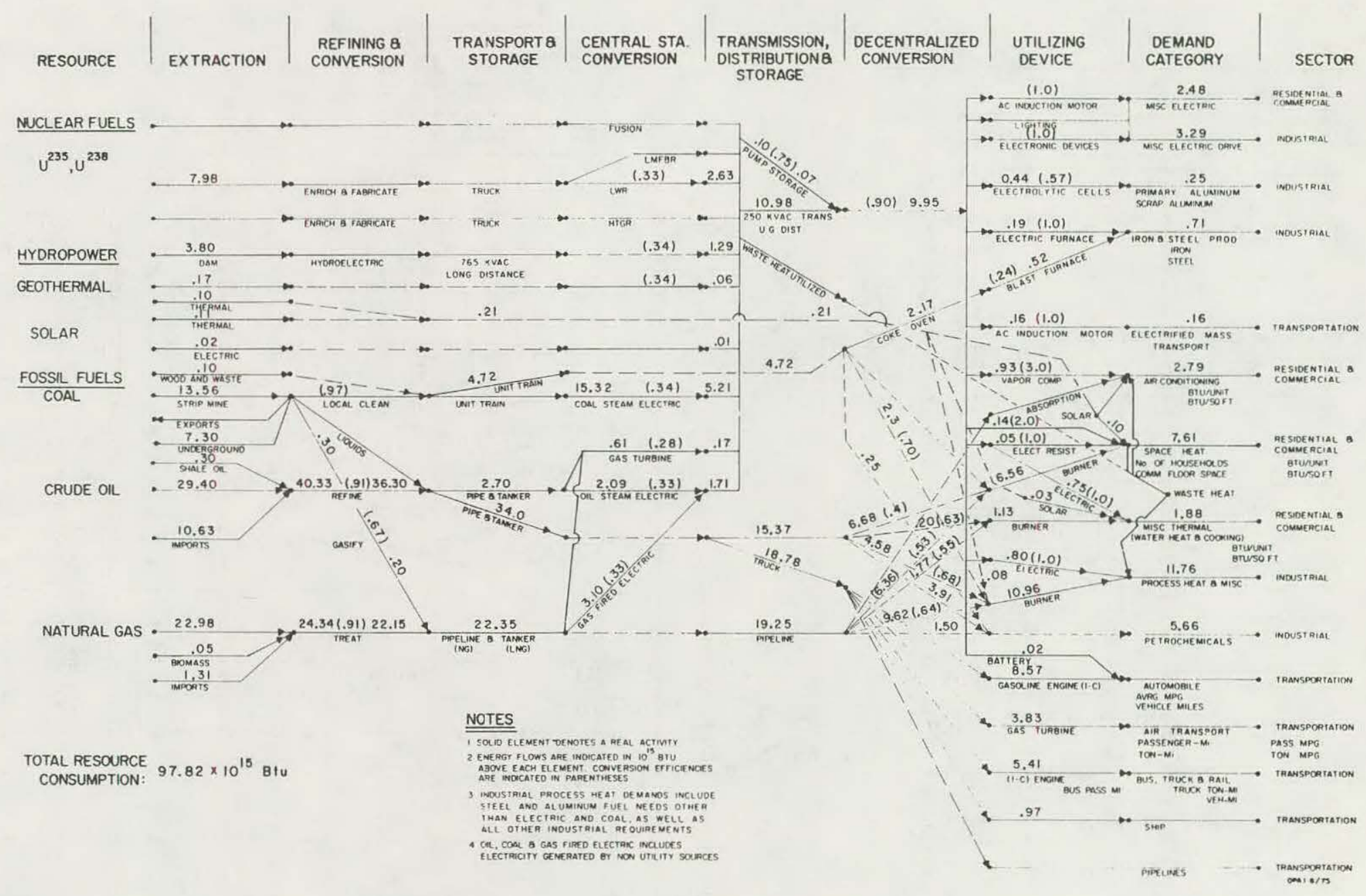

Figure 1. Reference energy system, year 1985-SF-2. 


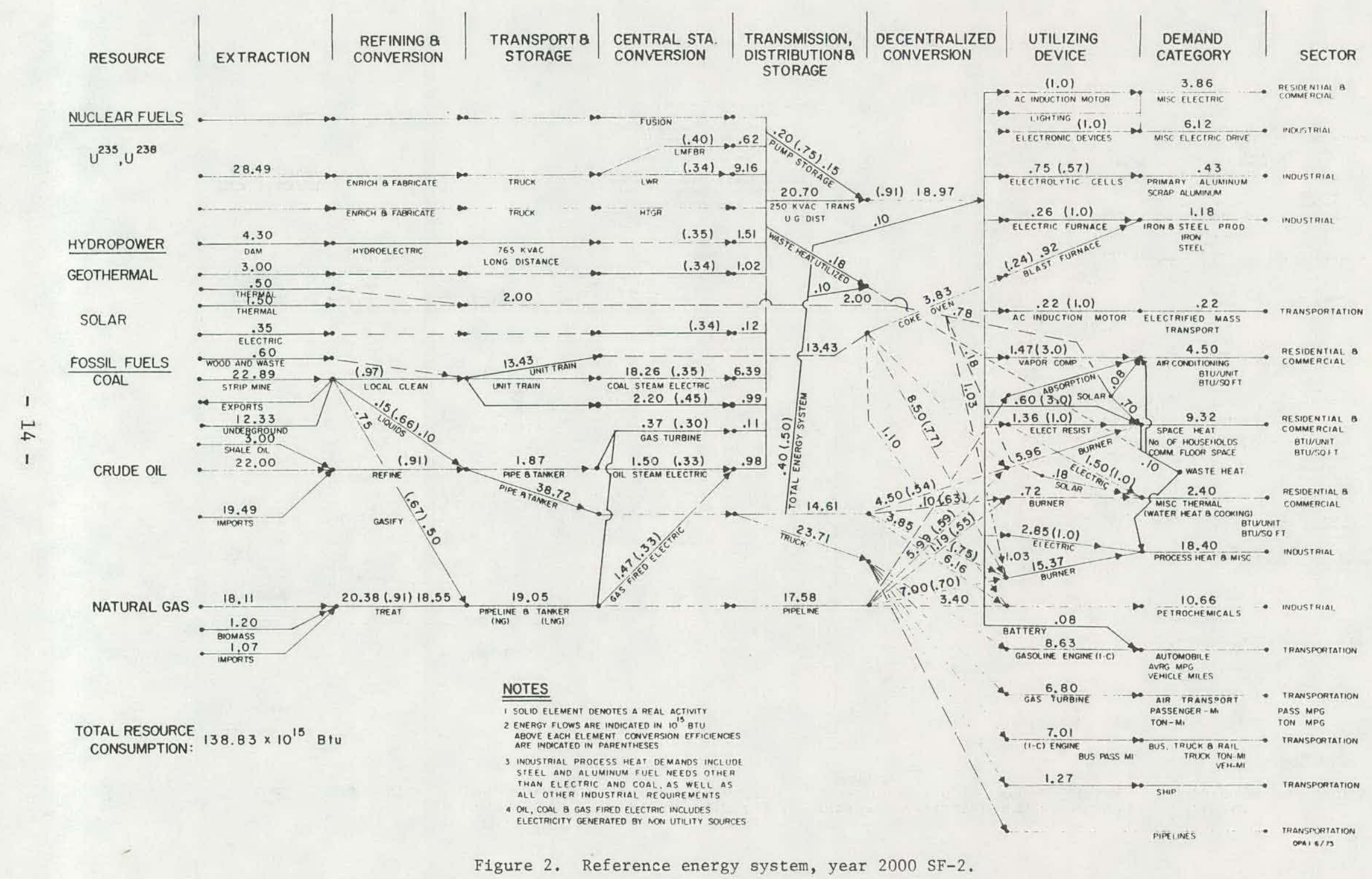




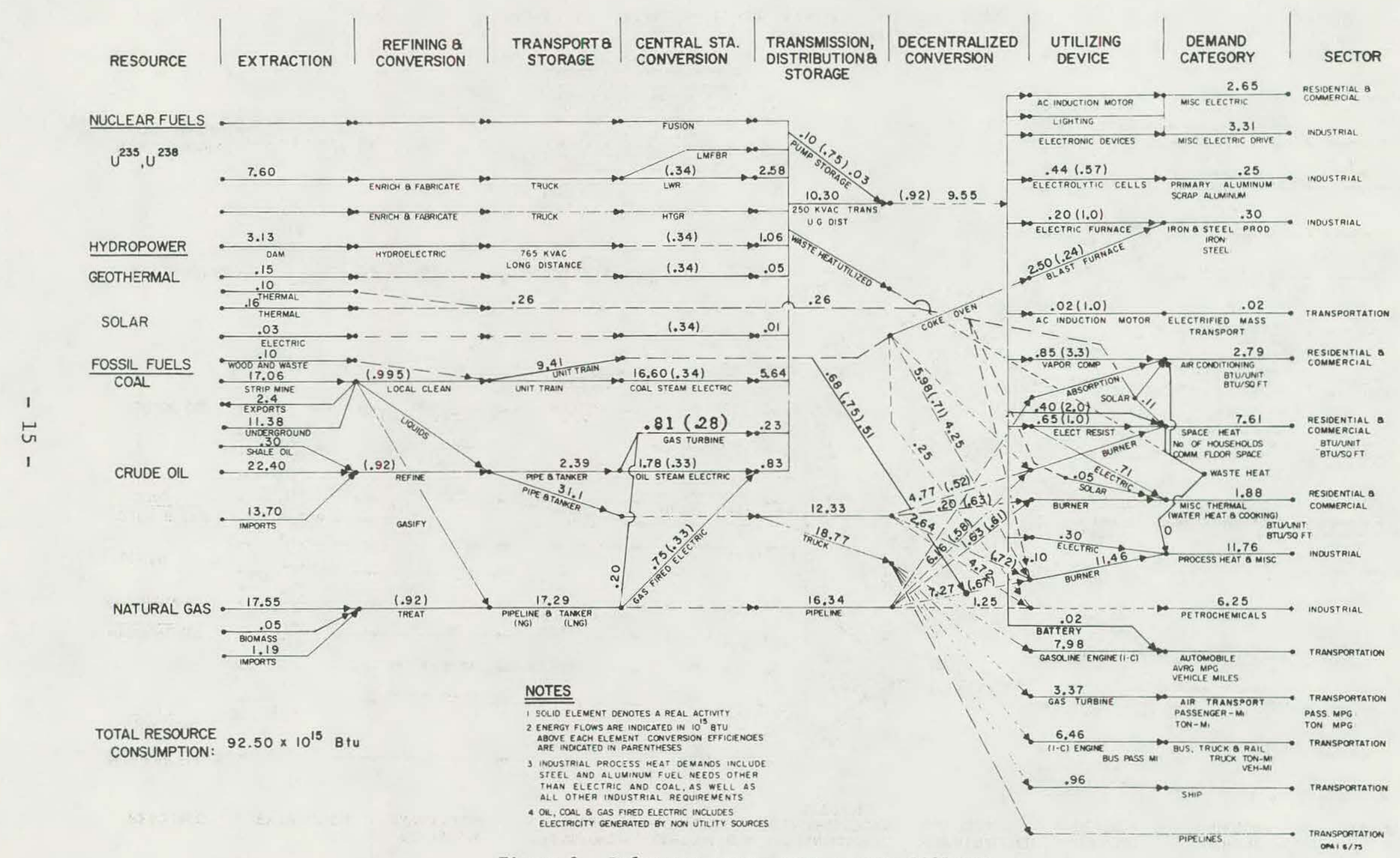

Figure 3. Reference energy system, year 1985 NEP. 


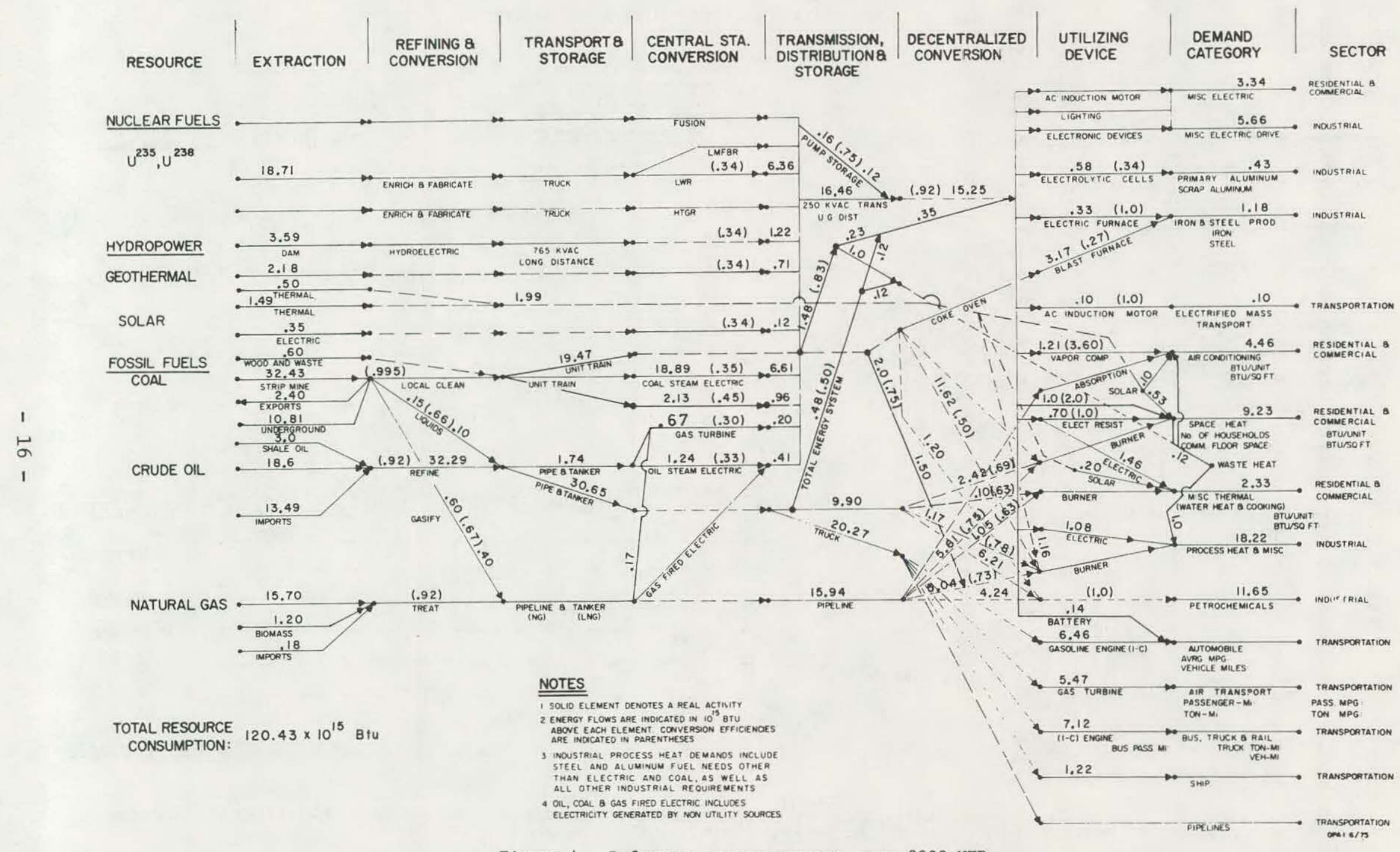

Figure 4. Reference energy system, year 2000 NEP. 
fuel not consumed by the utility) for cogenerated electricity. These credits were calculated on the basis of the change, between 1972 and 2000, in the amount of electricity purchased by the industry. (A sample calculation of cogeneration credit is given below.) The CONAES and ERDA efficiency improvements are summarized in Table 9.

A. Meeting the Efficiency Targets: Technologies

The efficiency targets in the ERDA scenarios imply such modest percent improvements in efficiency that meeting them does not require the assumption of any changes in technology, except in the case of aluminum reduction, for which this study specified that $75 \%$ of primary aluminum production would be by the Alcoa process by 2000 .

The efficiency targets in the CONAES scenarios, on the other hand, require considerable changes in technology. These changes are discussed below for each industry.

1. Cement. Since the net energy intensity of cement production in 1972 was 6.55 (in units of $10^{6} \mathrm{Btu} /$ short ton), the targets for CONAES $A$ and $B$ in 2000 are 3.93 and 4.13 respectively. These are quite possible to achieve if all new cement plants use the preheater dry process and if some kilns are converted from wet to dry process. Efficient dry process kilns can require an energy intensity as low as 2.80 . In this study the kiln outputs that were $-56 \%$ wet $-44 \%$ dry in 1972 were assumed to approech $90 \%$ dry - 10\% wet by 2000 for both CONAES scenarios.* Electric drive energy consumption was derived by using the CONAES fuel mix given in Table 10 (these figures are for CONAES A but were assumed to apply to $B$ also). Since the numbers given are multiples of 1972 fuel use, using all four of them

\footnotetext{
* It was also assumed that the wet process kilns in use in 2000 will have an energy intensity of 6.00 .
} 
Table 9

Efficiency Improvements* by 2000 From Base Year 1972 by Scenario (percent)

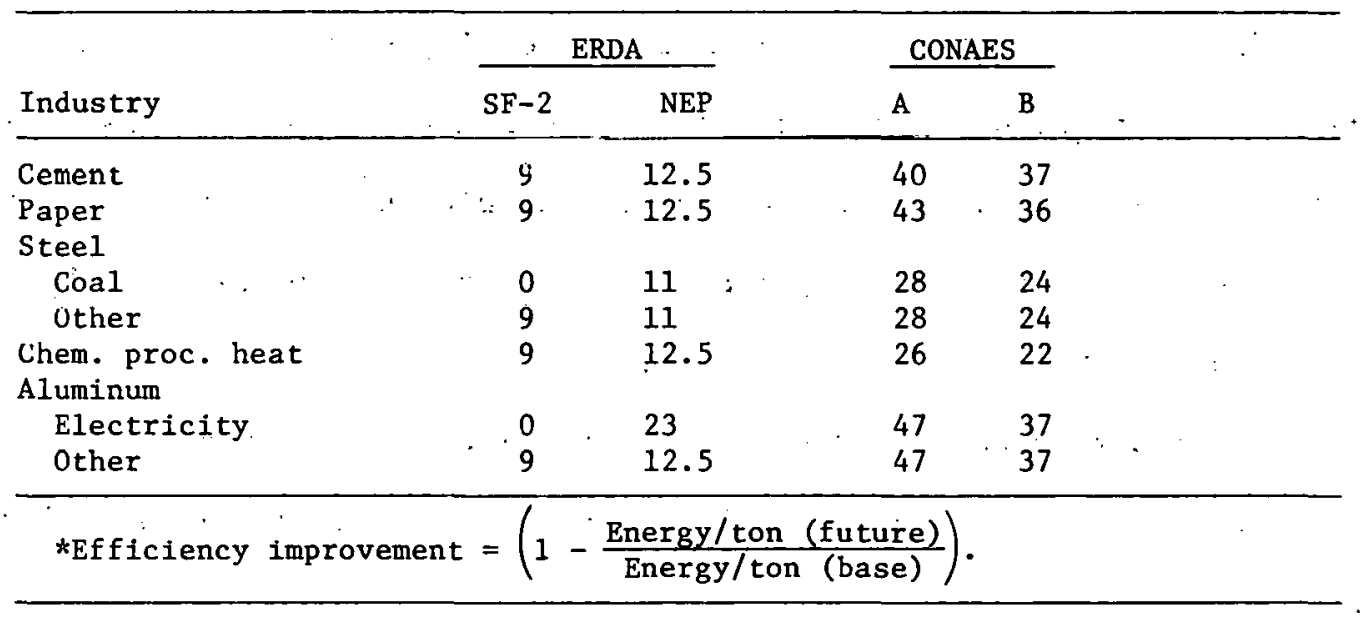

Table 10

Fractional Changes in Energy Use per Unit of Production by 2000 (CONAES scenario A; from ref. 1, Table 3a)

\begin{tabular}{lllll}
\hline Industry & Coal & Oil & Gas & Electricity \\
\hline Cement & 1.48 & 0.40 & 0.05 & 0.85 \\
Aluminum & 3.09 & 1.00 & 0.28 & 0.11 \\
Paper & 2.52 & 0.31 & 0.17 & 0.39 \\
Steel & 1.05 & 0.61 & 0.19 & 0.47 \\
Chem. proc. heat & 3.44 & 1.75 & 0.05 & 0.38 \\
\hline
\end{tabular}


proved inconsistent with the 1972 figures listed in Table 12. For the closest possible adherence to CONAES specifications, the Table 10 numbers were used for purchased electricity, and the coal:oil ratio used was about 90:10. This breakdown was used also for SF-2 and NEP. Natural gas was excluded from both CONAES and ERDA scenarios because it is unlikely to be used in the cement industry much 1onger. The resultant fossil fuels to the cement industry and the aggregated IEF mix are given in Tables 11 and 12, respectively, for 1972, 1985, and 2000.

2. Paper. The net energy intensity of purchased IEFs for paper and pulp production in 1972 of 21.10 (in units of $10^{6}$. Btu/short ton) yields targets for CONGES $A$ and $B$ in 2000 of 12.0 and 13.5 respectively. These are achieved as follows:

a. Cutting the steam demand of 21.9 by $10 \%$ through housekeeping measures such as better controls, improved paper-making processes, less water evaporation, etc., results in a savings of 2.2 in steam, which translates to a fuel savings (at $72 \%$ boiler efficiency) of $\underline{3.1}$.

b. For CONAES A, an increase by doubling bark and hogged wood use from 2.5 to 5.0 , and in $B$ an increase to 4.0 leaving the extra 1.0 in boiler fuel to generate steam, provides for A a savings of $\underline{2.3}$ in equivalent fossil fuel; for B a savings of $\underline{1.4}$.

c. Electric motor efficiency improvements and other housekeeping improvements in CONAES A to 2.9 from 3.1 saves $\underline{0.2}$ in purchased electricity for $A$, but this cannot be counted when adding to savings in d., below.

d. Cogenerating the remaining 5.0 steam requirement with high efficiency gas turbines, where $\mathrm{y}=0.34$ matio of electricity produced to fuel input. (All cogeneration in this study is assumed to use these highly cost-effective turbines.) These turbines produce 3.9 units of electricity so that 1.0 is 


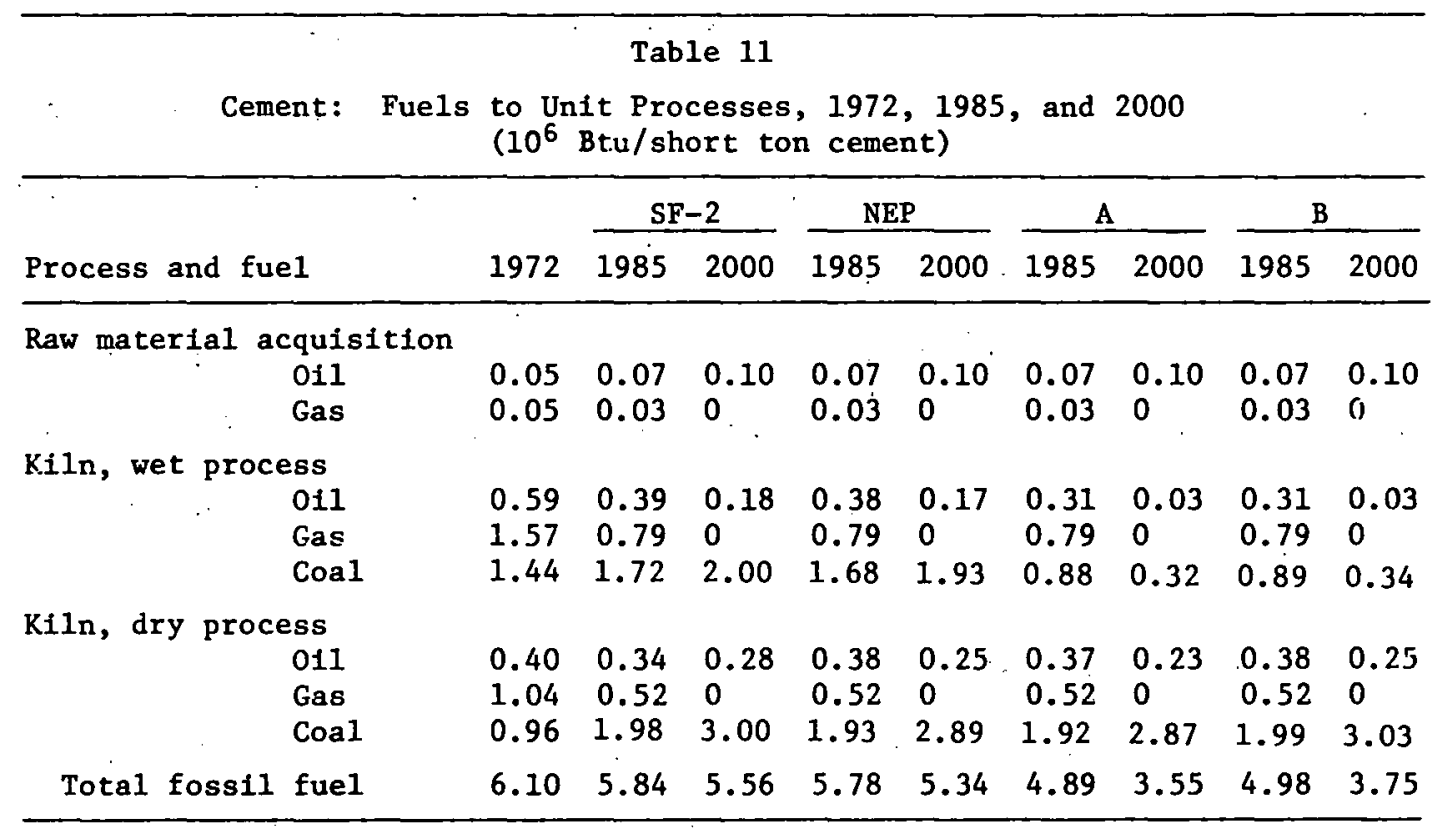

Table 12

Aggregate Fuel Mix per Ton of Cement $\left(10^{6} \mathrm{Btu} /\right.$ short ton)

\begin{tabular}{lccccccc}
\hline Scenario & Year & Coal & Oil & Gas & $\begin{array}{l}\text { Purch. } \\
\text { Elect. }\end{array}$ & Total & $\begin{array}{c}\text { Cogen. } \\
\text { Elect. }\end{array}$ \\
\hline \multirow{3}{*}{ SF-2 } & 1972 & 2.40 & 1.04 & 2.66 & 0.45 & 6.55 & 0 \\
& 1985 & 3.70 & 0.80 & 1.33 & 0.44 & 6.27 & 0 \\
NEP & 2000 & 5.00 & 0.56 & 0 & 0.43 & 5.99 & 0 \\
& 1985 & 3.62 & 0.78 & 1.33 & 0.44 & 6.17 & 0 \\
CONAES A & 2000 & 4.83 & 0.52 & 0 & 0.43 & 5.78 & 0 \\
\multirow{2}{*}{ CONAES B } & 1985 & 2.80 & 0.70 & 1.33 & 0.42 & 5.25 & 0 \\
& 2000 & 3.19 & 0.36 & 0 & 0.38 & 3.93 & 0 \\
& 1985 & 2.89 & 0.71 & 1.33 & 0.42 & 5.35 & 0 \\
\hline
\end{tabular}


exported to the utility grid in A, and 0.8 in B. (Savings from cogeneration are replaced at a rate of 3.37 units of fuel for each unit of 1972 purchased electricity, minus the difference in fuels used for steam generation and/or gas turbines, equals $\underline{3.6}$ for $\mathrm{A}$ and $\underline{3.0}$ for B.)

The results of making these changes are shown in Table 13. For botk SF-2 and NEP the fuel mix was determined by allowing gas to be used only for the lime kiln. For SF-2 oil was reduced to $25 \%$ of current usage, but for NEP, which is a high coal scenario, oil use for steam bollers was completely eliminated. The fuel mix for CONAES $A$ and $B$ was calculated from the percentage breakdown in Table 10 among fossil fuels. The results are: coal $74 \%$, oil $17 \%$, and gas $9 \%$. Purchased electricity was taken as zero because of the high cogeneration level. This assumption is necessary to reach the specified level of 3.1 quads of cogenerated electricity for CONAES B, and it was used for A also. The new aggregate fuel mix for paper for all scenarios in 1985 and 2000 appears in Table 14.

3. Aluminum. Since the net energy intensity of aluminum production in 1972 was 178.7 (in units of $10^{6} \mathrm{Btu} /$ short ton), the energy targets for CONAES A and B in 2000 are 94.6 and 113.0 respectively. These are achieved as follows.

a. Cutting the gas consumption for A1 heat treatment (20.5) by $20 \%$ through better combustion and material handling controls (via recuperators and revised furnace design) saves $\underline{4.1}$ in gas.

b. Cutting the steam requirement of the Bayer process for bauxite digesting by $15 \%$ * (from 25.0 to 21.2 ) through better insulation and process controls saves 4.7 in gas.

c. Introducing nonconsumable anodes into the aluminum reduction stage at the penetration leve1 of $100 \%$ for CONAES A and $50 \%$ for B saves energy, but, for B

*At the time this report was prepared, only the approximate numbers given in the text were available. 
Table 13

Paper: Fuels to Unit Processes, 1972, 1985, and 2000 ( $10^{6} \mathrm{Btu} /$ short ton paper)

\begin{tabular}{|c|c|c|c|c|c|c|c|c|c|}
\hline \multirow[b]{2}{*}{ Frocess and fuel } & \multirow[b]{2}{*}{1972} & \multicolumn{2}{|c|}{$S F-2$} & \multicolumn{2}{|c|}{ NEP } & \multicolumn{2}{|c|}{ A } & \multicolumn{2}{|c|}{ B } \\
\hline & & 1985 & 2000 & 1985 & 2000 & 1985 & 2000 & 1985 & 2000 \\
\hline $\begin{array}{l}\text { Pulping and bleaching } \\
\text { Wood and waste paper }\end{array}$ & 36.6 & 36.6 & 36.6 & 36.6 & 36.6 & 36.6 & 36.6 & 36.6 & 36.6 \\
\hline $\begin{array}{l}\text { Recovery and bark boiling } \\
\text { Bark and hogged wood } \\
\text { Black liquor }\end{array}$ & $\begin{array}{r}2.5 \\
12.5\end{array}$ & $\begin{array}{r}2.5 \\
12.5\end{array}$ & $\begin{array}{r}2.5 \\
12.5\end{array}$ & $\begin{array}{r}2.5 \\
12.5\end{array}$ & $\begin{array}{r}2.5 \\
12.5\end{array}$ & $\begin{array}{r}3.7 \\
12.5\end{array}$ & $\begin{array}{r}5.0 \\
12.5\end{array}$ & $\begin{array}{r}3.2 \\
12.5\end{array}$ & $\begin{array}{r}4.0 \\
12.5\end{array}$ \\
\hline $\begin{array}{l}\text { Lime kiln } \\
\text { Gas } \\
\text { Gill }\end{array}$ & $\begin{array}{l}1.6 \\
0\end{array}$ & $\begin{array}{l}1.5 \\
0\end{array}$ & $\begin{array}{l}1.4 \\
0\end{array}$ & $\begin{array}{l}1.5 \\
0\end{array}$ & $\begin{array}{l}1.4 \\
0\end{array}$ & $\begin{array}{l}1.4 \\
0.2\end{array}$ & $\begin{array}{l}1.1 \\
0.5\end{array}$ & $\begin{array}{l}1.4 \\
0.2\end{array}$ & $\begin{array}{l}1.2 \\
0.4\end{array}$ \\
\hline $\begin{array}{l}\text { Steam boilers } \\
\text { Oil } \\
\text { Gas } \\
\text { Coal }\end{array}$ & $\begin{array}{l}8.2 \\
5.8 \\
3.8\end{array}$ & $\begin{array}{l}5.2 \\
3.0 \\
8.9\end{array}$ & $\begin{array}{r}2.1 \\
0.2 \\
14.1\end{array}$ & $\begin{array}{l}4.1 \\
3.1 \\
9.5\end{array}$ & $\begin{array}{r}0 \\
0.3 \\
15.3\end{array}$ & $\begin{array}{l}4.1 \\
2.9 \\
3.2\end{array}$ & $\begin{array}{l}0 \\
0 \\
2.5\end{array}$ & $\begin{array}{l}4.1 \\
2.9 \\
3.6\end{array}$ & $\begin{array}{l}0 \\
0 \\
3.4\end{array}$ \\
\hline $\begin{array}{l}\text { Gas turbine } \\
\text { Oil } \\
\text { Gas } \\
\text { Coal (f1. bed combust.) }\end{array}$ & $\begin{array}{l}0 \\
0 \\
0\end{array}$ & $\begin{array}{l}0 \\
0 \\
0\end{array}$ & $\begin{array}{l}0 \\
0 \\
0\end{array}$ & $\begin{array}{l}0 \\
0 \\
0\end{array}$ & $\begin{array}{l}0 \\
0 \\
0\end{array}$ & $\begin{array}{l}0.7 \\
0 \\
5.0\end{array}$ & $\begin{array}{c}1.5 \\
0 \\
10.0\end{array}$ & $\begin{array}{l}0.9 \\
0 \\
4.8\end{array}$ & $\begin{array}{l}1.9 \\
0 \\
9.6\end{array}$ \\
\hline $\begin{array}{l}\text { Utility credit for cogeneration } \\
\text { Coal only }\end{array}$ & 0 & 0 & 0 & 0 & 0 & -1.8 & -3.6 & -1.5 & -3.0 \\
\hline Total fossil fuel & 19.4 & 18.6 & 17.8 & 18.2 & 17.0 & 15.7 & 12.0 & 16.4 & 13.5 \\
\hline
\end{tabular}

Table 14

Aggregate Fuel Mix per Ton of Paper $\left(10^{6} \mathrm{Btu} / \mathrm{short}\right.$ ton)

\begin{tabular}{|c|c|c|c|c|c|c|c|}
\hline Scenario & Year & Coal & Oil & Gas & $\begin{array}{l}\text { Purch. } \\
\text { elect. }\end{array}$ & Total & $\begin{array}{l}\text { Cogen. } \\
\text { elect. }\end{array}$ \\
\hline & 1972 & 3.80 & 8.20 & 7.70 & 1.40 & 21.1 & 1.70 \\
\hline$S F-2$ & $\begin{array}{l}1985 \\
2000\end{array}$ & $\begin{array}{r}8.95 \\
14.09\end{array}$ & $\begin{array}{l}5.14 \\
2.08\end{array}$ & $\begin{array}{l}4.51 \\
1.62\end{array}$ & $\begin{array}{l}1.41 \\
1.43\end{array}$ & $\begin{array}{l}20.16 \\
19.22\end{array}$ & $\begin{array}{l}1.70 \\
1.69\end{array}$ \\
\hline NEP & $\begin{array}{l}1985 \\
2000\end{array}$ & $\begin{array}{r}9.56 \\
15.32\end{array}$ & $\begin{array}{l}4.1 \\
0\end{array}$ & $\begin{array}{l}4.55 \\
1.69\end{array}$ & $\begin{array}{l}1.41 \\
1.43\end{array}$ & $\begin{array}{l}19.77 \\
18.44\end{array}$ & $\begin{array}{l}1.70 \\
1.69\end{array}$ \\
\hline CONAES A & $\begin{array}{l}1985 \\
2000\end{array}$ & $\begin{array}{l}6.34 \\
8.88\end{array}$ & $\begin{array}{l}5.12 \\
2.04\end{array}$ & $\begin{array}{l}4.24 \\
1.08\end{array}$ & $\begin{array}{l}0.70 \\
0\end{array}$ & $\begin{array}{l}16.40 \\
12.00\end{array}$ & $\begin{array}{l}1.95 \\
3.90\end{array}$ \\
\hline CONAES B & $\begin{array}{l}1985 \\
2000\end{array}$ & $\begin{array}{l}6.90 \\
9.99\end{array}$ & $\begin{array}{l}5.25 \\
2.30\end{array}$ & $\begin{array}{l}4.31 \\
1.21\end{array}$ & $\begin{array}{l}0.70 \\
0\end{array}$ & $\begin{array}{l}17.16 \\
13.50\end{array}$ & $\begin{array}{l}1.95 \\
3.90\end{array}$ \\
\hline
\end{tabular}


and for the two ERDA scenarios, all future new plants with combustible anodes will likely be of the prebake type, which increases energy use considerably. In Table 15, the resulting energy consumption for anodes, given under the first, sixth, and seventh items, shows a savings of $\underline{25.2}$ for A and a loss of $\underline{1.0}$ for B. d. The new Alcoa process for alumina reduction is assumed to use $40 \% 1$ less electricity than the Hail process and to burn $20 \%$ less anode when consumable anodes are used. Its introduction into scenarios NEP, CONAES, and CONAES B at penetrations of $75 \%, 90 \%$, and $90 \%$, respectively, for new plants* would save $\underline{19.8}$ in purchased electricity (coal and gas savings were included in c., above).

e. Improving the insulation and operating and combustion controls of the alumina calciner to cut gas consumption by $20 \%^{\circ}$ (from 7.8 to 6.1 ) would save 1.7. in gas.

f. Improving the average efficiency of the self-generation of electricity in reduction facilities from gas from 0.3 to 0.35 for CONAES $B$ and to 0.31 for CONAES A would achieve gas savings of $\underline{7.7}$ and $\underline{1.7}$, respectively.

g. Utilizing $22 \%$ of the off-gases (11.1) in the industry for CONAES $B$ as a gas-turbine fuel would save 2.4 in gas:

h. Cogenerating the remaining 21.2 in steam load for the Bayer process by... high efficlency gas turbines, as in the paper industry, produces 16.5 in net electricity and uses 48.8 in fuel to the gas turbines, with 25.8 previousiy used to raise the steam. Giving the industry credit for the heat for electricity purchased in 1972 and no longer required provides a savings of $\underline{32.7}$.

These process modifications, combined with the fuel mix for nonferrous metals calculated from Table 10 (coal $60 \%$, oil $11 \%$, and gas $29 \%$ ) give the

\footnotetext{
*At the time this report was prepared, on $1 y$ the approximate numbers given in the text were available.
} 
Table 15

Primary Aluminum: Fuels to Unit Processes, 1972, 1985, and 2000 (106 $\mathrm{Btu} / \mathrm{short}$ ton A1)

\begin{tabular}{|c|c|c|c|c|c|c|c|c|c|}
\hline \multirow[b]{2}{*}{ Process and fuel } & \multirow{2}{*}{1.972} & \multicolumn{2}{|c|}{$\mathrm{SF}-2$} & \multicolumn{2}{|c|}{ NEP } & \multicolumn{2}{|r|}{ A } & \multicolumn{2}{|c|}{ B } \\
\hline & & 1985 & 2000 & 1985 & 2000 & 1985 & 2000 & 1985 & 2000 \\
\hline $\begin{array}{l}\text { Al smelter } \\
\text { Coal (anode coke) }\end{array}$ & $13: 8$ & 13.8 & 13.8 & 12.2 & 10.6 & 0 & 0 & 12.6 & 11.3 \\
\hline $\begin{array}{l}\text { Alumina calciner } \\
\text { Gas }\end{array}$ & 7.8 & 7.5 & 7.1 & 7.3 & 6.8 & 7.0 & 6.1 & 7.0 & 6.1 \\
\hline $\begin{array}{l}\text { Steam boilers Al refining } \\
\text { Gas } \\
\text { Oil } \\
\text { Coal }\end{array}$ & $\begin{array}{c}18.8 \\
11.7 \\
0\end{array}$ & $\begin{array}{r}16.4 \\
5.9 \\
7.0\end{array}$ & $\begin{array}{c}13.9 \\
0.9 \\
13.9\end{array}$ & $\begin{array}{r}12.6 \\
5.9 \\
10.5\end{array}$ & $\begin{array}{l}6.4 \\
0 \\
21.1\end{array}$ & $\begin{array}{l}9.4 \\
5.9 \\
0\end{array}$ & $\begin{array}{l}0 \\
0 \\
0\end{array}$ & $\begin{array}{l}9.4 \\
5.9 \\
0\end{array}$ & $\begin{array}{l}0 \\
0 \\
0\end{array}$ \\
\hline $\begin{array}{l}\text { Stean boilers for turbines } \\
\text { Gas } \\
\text { Oil } \\
\text { Coal } \\
\text { Off-gas }\end{array}$ & $\begin{array}{c}52.0 \\
0 \\
0 \\
0\end{array}$ & $\begin{array}{c}34.2 \\
0 \\
14.2 \\
0\end{array}$ & $\begin{array}{c}16.4 \\
0 \\
28.4 \\
0\end{array}$ & $\begin{array}{c}26.0 \\
0 \\
23.3 \\
0\end{array}$ & $\begin{array}{c}0 \\
0 \\
46.7 \\
0\end{array}$ & $\begin{array}{c}26.0 \\
0 \\
24.9 \\
0\end{array}$ & $\begin{array}{c}0 \\
0 \\
49.9 \\
0\end{array}$ & $\begin{array}{l}26.0 \\
0 \\
20.9 \\
1.2\end{array}$ & $\begin{array}{r}0 \\
0 \\
41.9 \\
2.4\end{array}$ \\
\hline $\begin{array}{l}\text { Gas turbines for Al refng. cogen. } \\
\text { Gas } \\
\text { Oil } \\
\text { Coal ( } 1 \text {. bed combust.) }\end{array}$ & $\begin{array}{l}0 \\
0 \\
0\end{array}$ & $\begin{array}{l}0 \\
0 \\
0\end{array}$ & $\begin{array}{l}0 \\
0 \\
0\end{array}$ & $\begin{array}{l}0 \\
0 \\
0\end{array}$ & $\begin{array}{l}0 \\
0 \\
0\end{array}$ & $\begin{array}{r}1.2 \\
4.8 \\
18.3\end{array}$ & $\begin{array}{r}2.5 \\
9.7 \\
36.6\end{array}$ & $\begin{array}{r}.9 \\
5.8 \\
17.6\end{array}$ & $\begin{array}{r}1.9 \\
11.7 \\
35.2\end{array}$ \\
\hline $\begin{array}{l}\text { Anode coke mfr. } \\
\text { Gas } \\
\text { Coal }\end{array}$ & $\begin{array}{l}2.6 \\
0.3\end{array}$ & $\begin{array}{l}2.6 \\
0.3\end{array}$ & $\begin{array}{l}2.6 \\
0.3\end{array}$ & $\begin{array}{l}2.3 \\
0.3\end{array}$ & $\begin{array}{l}2.0 \\
0.2\end{array}$ & $\begin{array}{l}1.9 \\
0.2\end{array}$ & $\begin{array}{l}1.1 \\
0\end{array}$ & $\begin{array}{l}2.4 \\
0.3\end{array}$ & $\begin{array}{l}2.1 \\
0.2\end{array}$ \\
\hline $\begin{array}{l}\text { Anod prebake } \\
\text { Gas } \\
\text { Coal }\end{array}$ & $\begin{array}{l}3.1 \\
5.4\end{array}$ & $\begin{array}{l}4.4 \\
7.7\end{array}$ & $\begin{array}{r}5.8 \\
10.1\end{array}$ & $\begin{array}{l}3.8 \\
6.6\end{array}$ & $\begin{array}{l}4.5 \\
7.8\end{array}$ & $\begin{array}{l}1.6 \\
2.7\end{array}$ & $\begin{array}{l}0 \\
0\end{array}$ & $\begin{array}{l}3.8 \\
6.7\end{array}$ & $\begin{array}{l}4.6 \\
8.0\end{array}$ \\
\hline $\begin{array}{l}\text { Heat treat. and casting } \\
\text { Gas } \\
\text { Oil }\end{array}$ & $\begin{array}{c}20.5 \\
0\end{array}$ & $\begin{array}{c}19.6 \\
0\end{array}$ & $\begin{array}{c}18.7 \\
0\end{array}$ & $\begin{array}{c}19.2 \\
0\end{array}$ & $\begin{array}{c}17.9 \\
0\end{array}$ & $18.5^{\circ}$ & $\begin{array}{c}16.4 \\
0\end{array}$ & $\begin{array}{c}18.5 \\
0\end{array}$ & $\begin{array}{c}16.4 \\
0\end{array}$ \\
\hline $\begin{array}{l}\text { Utility crecit for cogeneration } \\
\text { Coal }\end{array}$ & 0 & 0 & 0 & 0 & 0 & -16.3 & -32.7 & -16.3 & -32.7 \\
\hline Total fossil fuel & 136.0 & 133.5 & 131.0 & 130.0 & 124.0 & 112.3 & 88.5 & 121.2 & 106.7 \\
\hline
\end{tabular}


results in Table 15. The fuel mix for the ERDA scenarios in 2000 was calculated on the basis of a 50-50 coal-gas split for SF-2, and a 70-30 split for NEP, leaving gas available at least for heat treatment. No oil use was assumed in view of the ERDA oil conservation constraints, especially for NEP. The aggregate fuel mix per ton for all scenarios appears in Table 16.

\begin{tabular}{|c|c|c|c|c|c|c|c|}
\hline & Aggregate & Fuel Mix & per Ton & $\begin{array}{l}\text { le } 16 \\
\text { f Aluminum }\end{array}$ & $\left(10^{6} \cdot \mathrm{Btu}\right.$ & ort ton): & \\
\hline Scenario & Year & Coal & 011 & Gas & $\begin{array}{l}\text { Purch. } \\
\text { elect. }\end{array}$ & Total & $\begin{array}{l}\text { Cogen. } \\
\text { elect. }\end{array}$ \\
\hline & 1972 & 19.5 & 11.7 & 104.8 & 42.7 & 178.7 & 18.1 \\
\hline $\mathrm{SF}-2$ & $\begin{array}{l}1985 \\
2000\end{array}$ & $\begin{array}{l}40.96 \\
62.42\end{array}$ & $\begin{array}{l}5.9 \\
0\end{array}$ & $\begin{array}{l}84.67 \\
64.33\end{array}$ & $\begin{array}{l}42.7 \\
42.68\end{array}$ & $\begin{array}{l}174.07 \\
169.43\end{array}$ & $\begin{array}{l}16.8 \\
17.8\end{array}$ \\
\hline NEP & $\begin{array}{l}1985 \\
2000\end{array}$ & $\begin{array}{l}51.47 \\
83.44\end{array}$ & $\begin{array}{l}5.9 . \\
0\end{array}$ & $\begin{array}{l}70.97 \\
36.94\end{array}$ & $\begin{array}{l}37.91 \\
33.12\end{array}$ & $\begin{array}{l}166.10 \\
153.50\end{array}$ & $\begin{array}{l}14.9 \\
14.01\end{array}$ \\
\hline CONAES A & $\begin{array}{l}1985 \\
2000\end{array}$ & $\begin{array}{l}36.4 \\
53.3\end{array}$ & $\begin{array}{r}10.7 \\
9.7\end{array}$ & $\begin{array}{l}64.9 \\
25.0\end{array}$ & $\begin{array}{r}24.6 \\
6.4\end{array}$ & $\begin{array}{r}136.6 \\
94.6\end{array}$ & $\begin{array}{l}26.4 \\
34.6\end{array}$ \\
\hline CONAES B & $\begin{array}{l}1985 \\
2000\end{array}$ & $\begin{array}{l}41.7 \\
63.8\end{array}$ & $\begin{array}{l}11.7 \\
11.7\end{array}$ & $\begin{array}{l}68.0 \\
31.1\end{array}$ & $\begin{array}{r}24.6 \\
6.4\end{array}$ & $\begin{array}{l}146.0 \\
113.0\end{array}$ & $\begin{array}{l}26.4 \\
34.6\end{array}$ \\
\hline
\end{tabular}

4. Steel. In 1972 the steel industry's requirement was 23.22 units $\left(10^{6}\right.$ Btu/short ton) of net purchased IEFs to produce raw steel, implying targets of 16.8 and 17.6 for CONAES A and B respectively. With use of many of the Thermoelectron estimates, 4 these targets were achieved by the following technological changes.

a. Use of dry, rather than wet, quenching of coke recovery of about $80 \%$ of the sensible heat in the coke emerging from the coke ovens, which can be used to preheat combustion air and feedwater. This change is of great envirommental significance as it markedly reduces the ovens particulate emissions, and it saves about $\underline{0.4}$ in fossil fuels. 
b. Increasing the top pressure and wind rate in the blast furnace heightens the furnace efficiency: generally and therefore decreases coke consumption by as much as 100 lb per ton of pig iron and thus saves about $\underline{0.8}$ in coke.

c. The elimination of remaining open hearth steel furnaces will probably. be completed by the continuation of present trends, and presumably all new steel furnaces will be of the basic oxygen type. The proportion of electric arc furnaces is assumed to remain constant. This is possible if waste heat in the steel plant is used to preheat scrap, which would allow a higher scrap charge than that currently used in the basic oxygen furnaces, to make up for the higher scrap charge of the open hearths. These changes result in a savings of about 0.7 in oil and gas.

d. Increasing cogeneration to provide the total steam requirement of 2.3 could be accomplished by high efficiency gas turbines using only 5.3 in fuel and generating 1.8 of electricity,besides the 2.3 in steam. Since the industry requires only 1.3 of electricity, 0.5 could be transferred to the utility grid, for a savings of about $\underline{3.8}$ as cogeneration credit.

e. For CONAES A only, continuous casting could be implemented for $40 \%$ of steel poured. This change is somewhat dependent on the structural requirements of the finished steel and on developing the proper rolling techniques. It saves energy directly by reducing energy use in casting and indirectly by reducing home scrap losses, for a total savings of $\widetilde{0.4}$ in oil and gas.

f. If, for CONAES A only, insulation and capture of waste heat from reheat furnaces saved about $10 \%$ of the energy burned here, the savings in oil and gas would be about $\underline{0.4}$.

The resulting fuel consumption by the various unit processes in the steel industry is given in Table 17. For the CONAES scenarios for 2000, the fuel mix 
Table 17

Steel Process Heat: Fuels to Unft Processes, 1972, 1985, and 2000 (106 Btu/short ton raw steel)

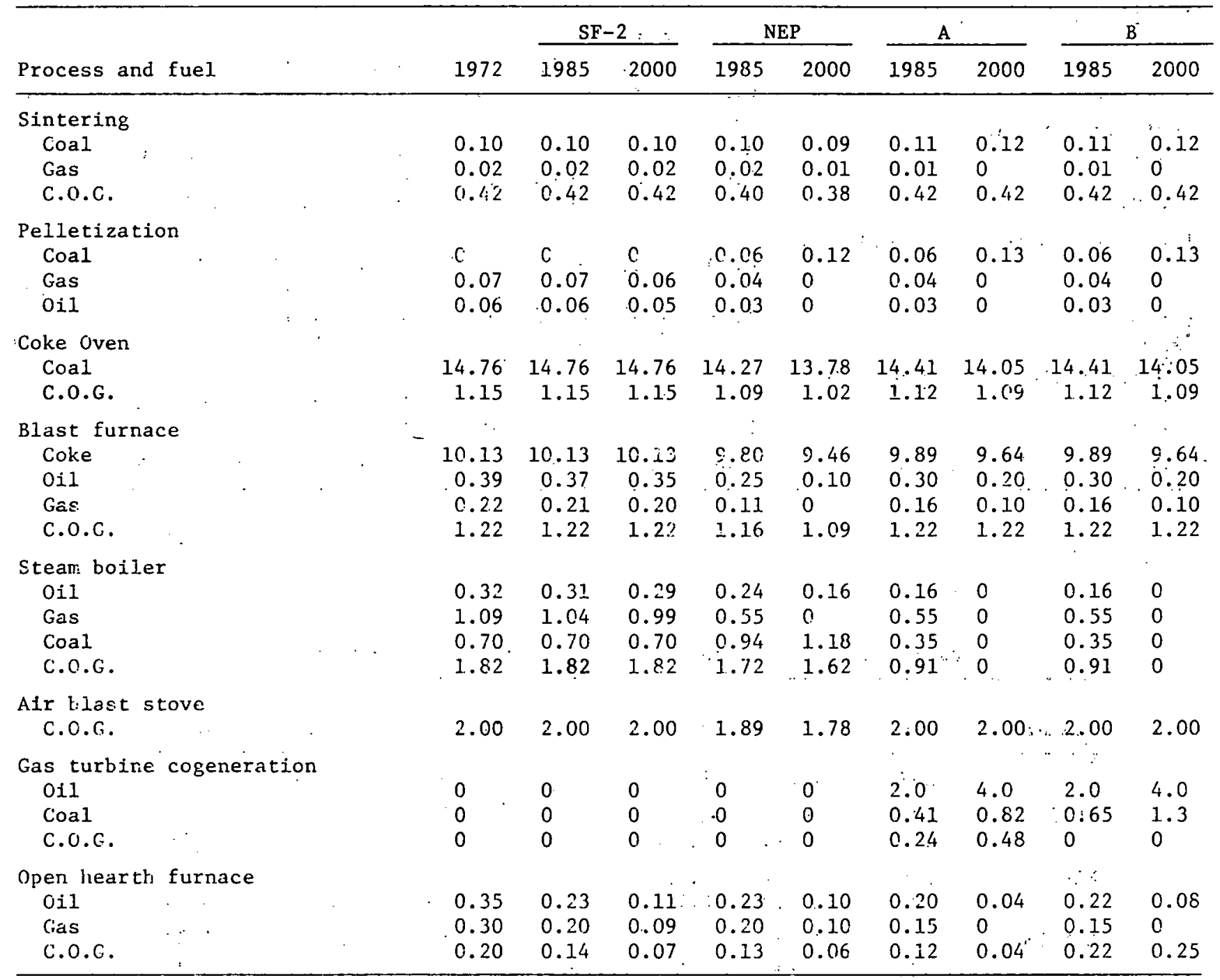




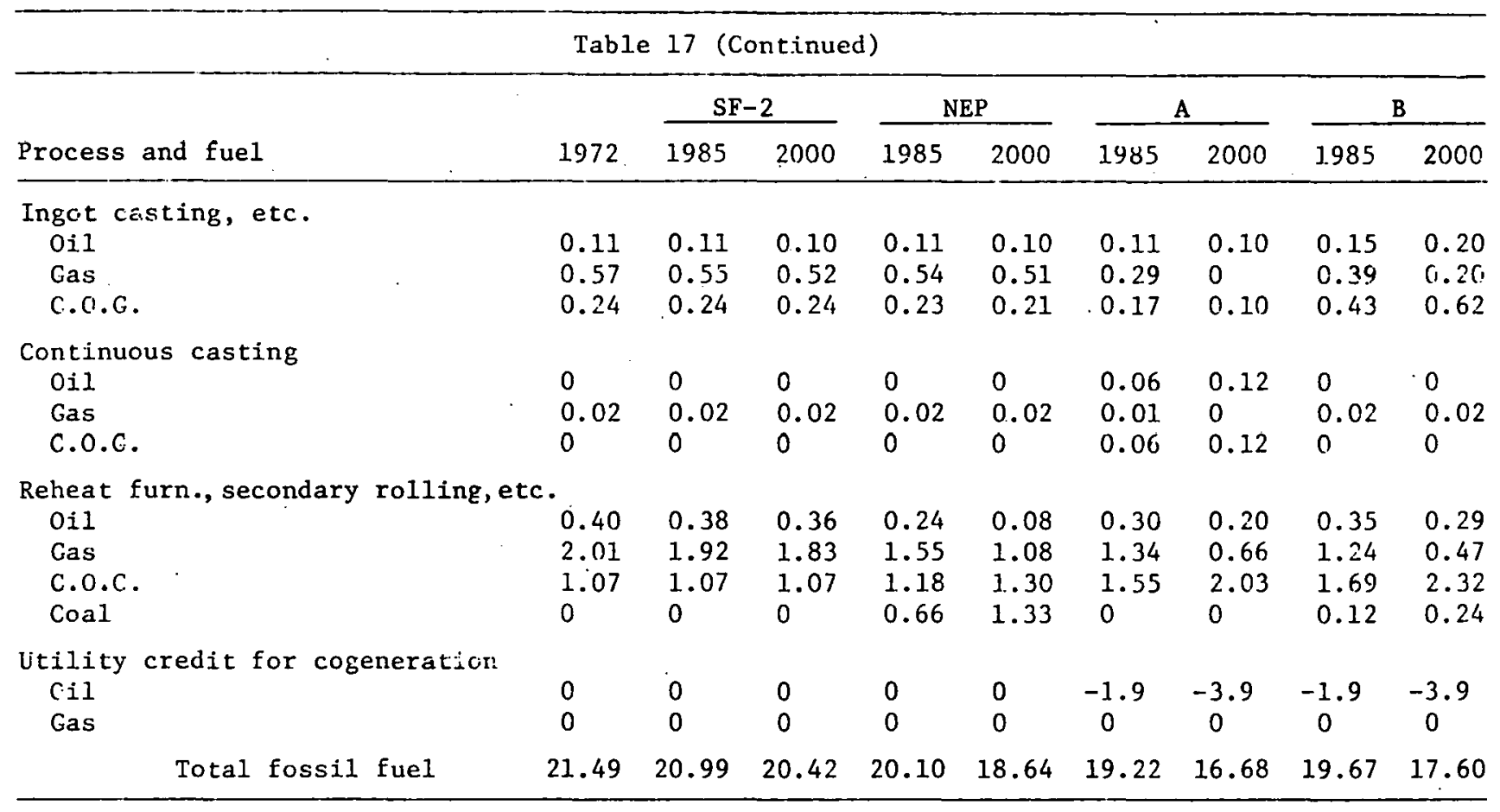

Table 18

Aggregate Fuel Mix per Ton of Steel $\left(10^{6} \mathrm{Btu} / \mathrm{short}\right.$ ton $)$

\begin{tabular}{llllllll}
\hline Scenario & Year & Coa1 & Oil & Gas & $\begin{array}{l}\text { Purch. } \\
\text { elect. }\end{array}$ & Total & $\begin{array}{l}\text { Cogen. } \\
\text { elect. }\end{array}$ \\
\hline \multirow{3}{*}{ SF-2 } & 1972 & 16.24 & 1.63 & 4.30 & 1.05 & 23.22 & 0.26 \\
& 1985 & 16.24 & 1.58 & 4.10 & 1.11 & 23.02 & 0.26 \\
NEP & 2000 & 16.23 & 1.52 & 3.90 & 1.17 & 22.82 & 0.26 \\
& 1985 & 16.67 & 1.19 & 3.10 & 1.24 & 22.20 & 0.26 \\
CONAES A & 1985 & 15.68 & 1.28 & 2.53 & 0.53 & 20.02 & 1.28 \\
\multirow{2}{*}{ CONAES B } & 2000 & 15.12 & 0.92 & 0.76 & 0 & 16.80 & 2.30 \\
& 1985 & 16.04 & 1.30 & 2.55 & 0.53 & 20.42 & 1.28 \\
& 2000 & 15.84 & 0.97 & 0.79 & 0 & 17.60 & 2.30 \\
\hline
\end{tabular}


was again determined by taking the percentages, calculated from Table 10 (coal $90 \%$, oil 5.5\%, and gas $4.5 \%$, with purchased electricity zero as a result of d., above. For SF-2 the current fuel mix was retained, since the current technologies were assumed to remain in use; for NEP, because it is a high coal scenario, gas and oil use per ton was reduced by half after the efficiency improvements were applied. The resulting aggregate fuel mix for each scenario appears in Table 18.

5. Chemicals. For the chemical industry, only very rough approximations could be made because the large number of final products involved and the time available for the study precluded detailed calculations. The proportion of direct heat, process steam, and electricity required by the entire industry relative to feedstock energy was projected to remain constant into the future for all scenarios. The direct heat and process steam requirements were then reduced by the percentages in Table 9 for the year 2000. To achieve the reductions for the CONAES scenarios it was assumed that the cogeneration of process steam and electricity increased sufficiently to effect about one-half the savings, with all other savings for all scenarios coming from housekeeping measures and fmproved heat exchange between process streams. For the CONAES scenarios, the fuel mix including purchased electricity was calculated from Table 10 in the usual way. The amount of cogenerated electricity was the remainder after subtraction of purchased electricity from the total electrical need. The conAES fuel mix for chemical process energy only was coal $58 \%$, oil $12.4 \%$, gas $25.4 \%$, and purchased electricity. $4.2 \%$. For SF-2 the fuel mix was kept the same as the current mix, and for NEP the oil percentage was held constant with the remainder divided $60-40$ between coal and gas. The chemical feedstock energy mix was specified for the ERDA scenarios. The CONAES constraints, however, forced an even stronger shift to coal, so that coal supplied about $50 \%$ of the feedstock energy--but much of this coal would likely be 
in liquified or gasified form. The resulting 'fuels to chemical unit processes appear in Tabel 19, and the aggregate fuel $\mathrm{mix}$ appears in Table 20, which summarizes the total fuels used in all industries.

6. Other. For CONAES A and B, the production of 3.1 quads of cogenerated electricity, explicitly required for $B$ in ref. 1, was taken as a strict constraint; therefore, all the cogenerated electricity assigned to the five industries discussed above was subtracted from 3.1. The resultant 1.01 for CONAES $A$ and 0.97 for $B$ seemed reasonable, since, of the total energy conserved by industry, the part falling into the "Other" category is also somewhat less than $30 \%$ (when the energy for all fuels for the five main industries is subtracted from the totals derived in Section II above). This breakdown is summarized in Tables 19 and 20.

Some observations about the breakdowns of industrial fuel use are relevant here. (1) Even though the NEP scenario requirement for all sectors is 18 quads less than the SF-2, the industrial sector uses almost the same quantity of fuel in NEP as in SF-2, so that the burden for conservation in NEP is clearly on the residential, commercial, and transportation sectors. (2) In both CONAES scenarios, energy consumption for the chemical industry as a whole (including asphalt, lubes, waxes, etc.) becomes about one-half of total industrial energy consumption if the implied growth rate is correct, and in NEP it is $44 \%$. (3) Comparison of CONAES and ERDA scenarios shows that cogeneration, when combined with conservation, can drastically reduce the purchased electricity demand in 2000 by industry, i.e., from the 9.98 quads in SF-2 to the 1.99 quads in CONAES A. Note that, according to the procedure used in this study, the fuels burned for cogeneration are burned at the industrial site, but the industry is given a fuel credit for the electricity no longer purchased, and this credit does not appear in Table 20 (or anywhere else) as fuel consumed by the industry but is assigned to the utility sector as part of its consumption. 
Table 19

Chen:ical and "Other" Process Heat:. Fuels to Unit Processes, 1972, 1985, and 2000 (quads)

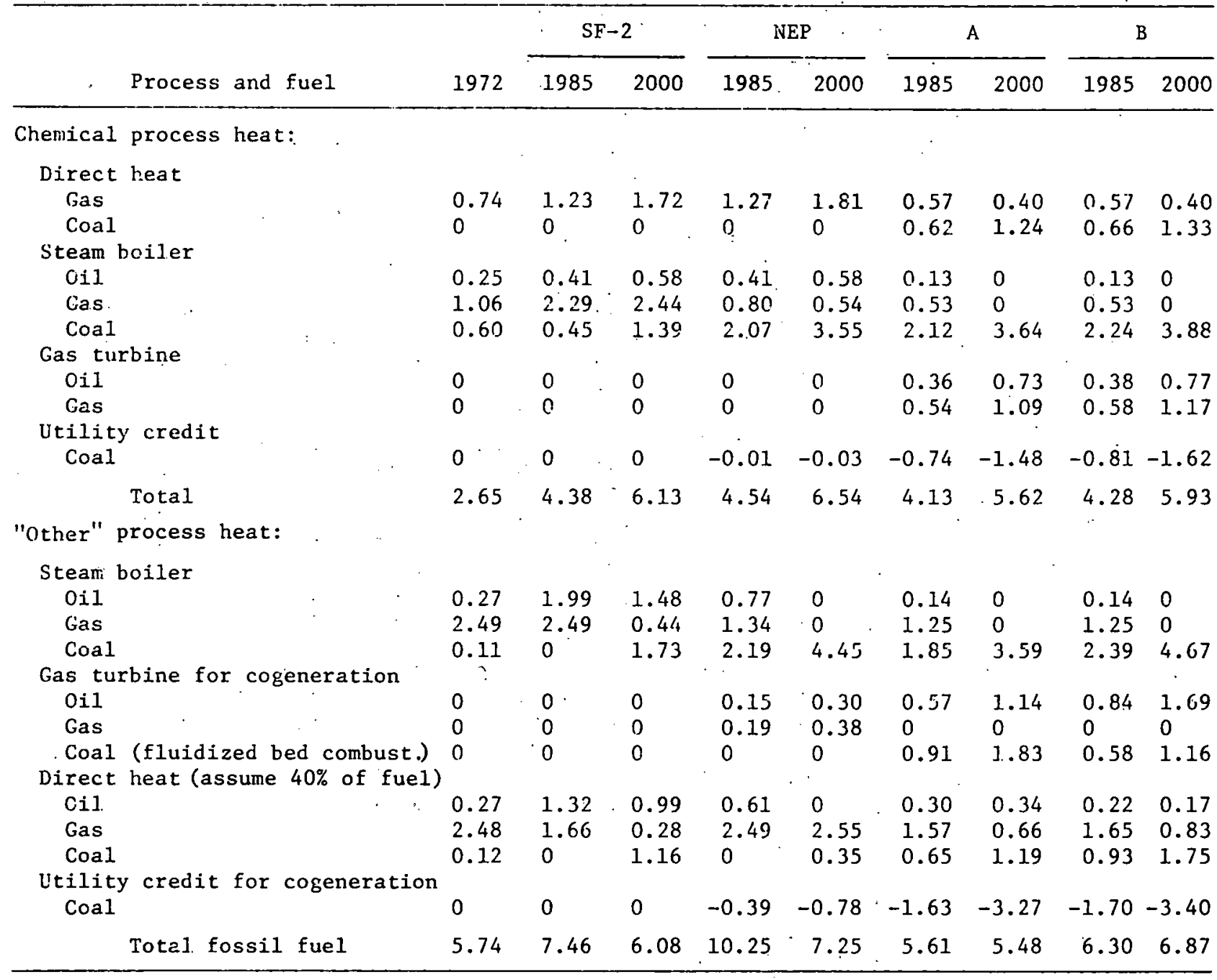


Table 20

Industry Fuel Mix Summary, 1972, 1985, and 2000 (quads)

\begin{tabular}{|c|c|c|c|c|c|c|c|c|c|c|c|c|c|c|c|}
\hline $\begin{array}{l}\text { Scen. } \\
\& y r .\end{array}$ & Indus & strial & Coal & $0 i 1$ & Gas & $\begin{array}{l}\text { Purch. } \\
\text { elect. }\end{array}$ & Total & $\begin{array}{l}\text { Cogen } \\
\text { elect. }\end{array}$ & - $\mathrm{Yr}$. & Coal & $0 i 1$ & Gas & $\begin{array}{l}\text { Purch. } \\
\text { elect. }\end{array}$ & Total & $\begin{array}{l}\text { Cogen } \\
\text { elect }\end{array}$ \\
\hline \multicolumn{16}{|l|}{ Base } \\
\hline \multirow[t]{8}{*}{1972} & \multirow{8}{*}{$\begin{array}{l}\text { Cement } \\
\text { Paper } \\
\text { Al } \\
\text { Chem. } \\
\text { Steel } \\
\text { Chem. } \\
\text { Other }\end{array}$} & & 0.20 & 0.09 & 0.22 & 0.04 & 0.55 & 0 & & & \multicolumn{5}{|l|}{. } \\
\hline & & & 0.25 & 0.48 & 0.45 & 0.11 & 1.29 & 0.10 & & & & & & & \\
\hline & & & 0.08 & 0.05 & 0.45 & 0.17 & 0.75 & 0.07 & & & & & & & \\
\hline & & p.h.* & 0.60 & 0.25 & 1.80 & 0.37 & 3.02 & 0.08 & & & & & & & \\
\hline & & & 2.20 & 0.22 & 0.57 & 0.14 & 3.13 & 0.04 & & & & & & & \\
\hline & & feed. & 0.13 & 3.39 & 0.67 & 0 & 4.19 & 0 & & & & & & & \\
\hline & & & 0.18 & 0.57 & 5.16 & 1.64 & 7.55 & 0 & & & & & & & \\
\hline & & Total & 3.64 & 5.01 & 9.1 .7 & 2.47 & 20.29 & 0.29 & & & & & & & \\
\hline \multicolumn{16}{|l|}{$S F-2$} \\
\hline \multirow[t]{8}{*}{1985} & \multirow{8}{*}{$\begin{array}{l}\text { Cement } \\
\text { Paper } \\
\text { A1 } \\
\text { Chem. } \\
\text { Steel } \\
\text { Chem. } \\
\text { Other }\end{array}$} & & 0.48 & 0.10 & 0.17 & 0.06 & 0.81 & 0 & 2000 & 1.16 & 0.13 & 0 & 0.10 & 1.39 & 0 \\
\hline & & & 0.83 & 0.48 & 0.42 & 0.13 & 1.86 & 0.16 & & 2.17 & 0.32 & 0.25 & 0.22 & 2.96 & 0.26 \\
\hline & & & 0.37 & 0.05 & 0.77 & 0.39 & 1.58 & 0.15 & & 0.98 & 0 & 1.01 & 0.67 & 2.66 & 0.28 \\
\hline & & p.h.* & 0.45 & 0.41 & 3.52 & 0.94 & 5.32 & 0.20 & 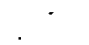 & 1.39 & 0.58 & 4.16 & 0.85 & 6.98 & 0.18 \\
\hline & & & 2.34 & 0.23 & 0.59 & 0.16 & 3.32 & 0.04 & & 3.75 & 0.35 & 0.90 & 0.27 & 5.27 & 0.06 \\
\hline & & feed. & 0.25 & 3.91 & 1.50 & 0 & 5.66 & 0 & & 1.10 & 6.16 & 3.40 & 0 & 10.66 & 0 \\
\hline & & & 0 & 3.31 & 4.1 .5 & 3.04 & 10.50 & 0 & & 2.88 & 2.47 & 0.68 & 7.87 & 13.90 & 0 \\
\hline & & Total & 4.72 & 8.49 & 11.12 & 4.72 & 29.05 & 0.55 & . & 13.43 & 10.01 & 10.40 & 9.98 & 43.82 & 0.78 \\
\hline \multirow{9}{*}{$\begin{array}{l}\text { NEP } \\
1985 \\
\end{array}$} & & & & & & & & & & & & & & & \\
\hline & \multirow{8}{*}{$\begin{array}{l}\text { Cement } \\
\text { Paper } \\
\text { Al } \\
\text { Chem. } \\
\text { Steel } \\
\text { Chem. } \\
\text { Other }\end{array}$} & & 0.47 & 0.10 & 0.17 & 0.06 & 0.80 & 0 & 2000 & 1.12 & 0.12 & 0 & 0.10 & 1.34 & 0 \\
\hline & & & 0.88 & 0.38 & 0.42 & 0.13 & 1.81 & 0.16 & & 2.35 & 0 & 0.26 & 0.22 & 2.84 & 0.26 \\
\hline & & & 0.47 & 0.05 & 0.65 & 0.34 & 1.51 & 0.14 & & 1.31 & 0 & 0.58 & 0.52 & 2.41 & 0.22 \\
\hline & & p.h.* & 2.07 & 0.41 & 2.07 & 1.03 & 5.58 & 0.22 & & 3.52 & 0.58 & 2.35 & 0.90 & 7.35 & 0.19 \\
\hline & & & 2.40 & 0.17 & 0.45 & 0.18 & 3.20 & 0.04 & & 3.95 & 0.17 & 0.44 & 0.33 & 4.89 & 0.06 \\
\hline & & feed. & 0.25 & 4.72 & 1.28 & 0 & 6.25 & 0 & & 1.20 & 6.21 & 4.24 & 0 & 11.65 & 0 \\
\hline & & & 2.19 & 1.53 & 4.02 & 2.51 & 10.25 & 0 & & 4.01 & 0.30 & 2.91 & 5.58 & 12.80 & 0.23 \\
\hline & & Total & 8.73 & 7.36 & 9.06 & 4.25 & 29.40 & 0.56 & & 17.47 & 7.38 & 10.78 & 7.65 & 43.28 & 0.96 \\
\hline \multicolumn{16}{|c|}{ 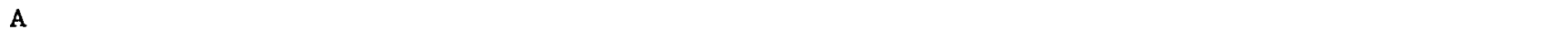 } \\
\hline \multirow[t]{8}{*}{1985} & \multirow{8}{*}{$\begin{array}{l}\text { Cement } \\
\text { Paper } \\
\text { Al } \\
\text { Chem. } \\
\text { Steel } \\
\text { Chem. } \\
\text { Other }\end{array}$} & & 0.28 & 0.07 & 0.13 & 0.04 & 0.52 & 0 & 2000 & 0.40 & 0.04 & 0 & 0.05 & .49 & 0 \\
\hline & & & 0.54 & 0.44 & 0.36 & 0.06 & 1.40 & 0.17 & & 1.16 & 0.27 & 0.14 & 0 & 1.57 & .51 \\
\hline & & & 0.26 & 0.08 & 0.46 & 0.17 & 0.97 & 0.19 & & 0.72 & 0.13 & 0.35 & 0.09 & 1.28 & .47 \\
\hline & & p.h.* & 2.00 & 0.49 & 1.28 & 0.31 & 4.08 & 0.31 & & 3.40 & 0.73 & 1.49 & 0.25 & 5.87 & .62 \\
\hline & & & 2.63 & 0.22 & 0.43 & 0.09 & 3.37 & 0.22 & & 3.22 & 0.20 & 0.16 & 0 & 3.58 & .49 \\
\hline & & feed. & 2.93 & 4.27 & 0.71 & 0 & 6.71 & 0 & & 5.74 & 5.16 & 0.76 & 0 & 11.56 & 0 \\
\hline & & & 1.79 & 1.01 & 2.82 & 1.62 & 7.24 & 0.51 & & 3.34 & 1.48 & 0.66 & 1.60 & 7.08 & 1.01 \\
\hline & & Total & 10.43 & 6.58 & 6.19 & 2.29 & 24.29 & 1.40 & & 17.98 & 8.01 & 3.55 & 1.99 & 31.43 & 3.10 \\
\hline \multirow{9}{*}{$\begin{array}{l}\text { B } \\
1985 \\
\end{array}$} & & & & & & & & & & & & & & & \\
\hline & Cement & & 0.28 & 0.07 & 0.13 & 0.04 & 0.52 & 0 & 2000 & 0.42 & 0.05 & 0 & 0.05 & 0.52 & 0 \\
\hline & Paper & & 0.59 & 0.45 & 0.37 & 0.06 & 1.47 & 0.17 & & 1.31 & 0.30 & 0.16 & 0 & 1.77 & 0.51 \\
\hline & $\mathrm{Al}$ & & 0.30 & 0.08 & 0.48 & 0.17 & 1.03 & 0.19 & & 0.86 & 0.16 & 0.41 & 0.09 & 1.52 & 0.47 \\
\hline & Chem. & $\mathrm{p} \cdot \mathrm{h} \cdot{ }^{*}$ & 2.10 & 0.51 & 1.32 & 0.31 & 4.24 & 0.33 & & 3.59 & 0.77 & 1.57 & 0.26 & 6.19 & 0.66 \\
\hline & Steel & & 2.69 & 0.22 & 0.43 & 0.09 & 3.43 & 0.22 & & 3.37 & 0.21 & 0.17 & 0 & 3.75 & 0.49 \\
\hline & Chem. & feed. & 2.98 & 4.37 & 0.70 & 0 & 6.75 & 0 & & 5.58 & 5.37 & 0.73 & 0 & 11.63 & 0 \\
\hline & other & & 2.21 & 1.20 & 2.90 & 1.71 & 8.02 & 0.49 & & 4.18 & 1.86 & 0.83 & 1.77 & 8.64 & 0.97 \\
\hline & & Total & 11.15 & 6.90 & 6.33 & 2.38 & 25.46 & 1.44 & & 19.58 & 8.72 & 3.87 & $\begin{array}{ll}7 & 2.17\end{array}$ & 34.34 & 3.10 \\
\hline
\end{tabular}




\section{EMISSION COEFFICIENTS BY INDUSTRY}

Emission coefficients were developed for the five major energy consuming industries considered above: pulp and paper, aluminum, iron and steel, cement, and chemicals. Emission levels for each pollutant are reported in pounds of emission per short ton of product output for the base year and for each scenario year. The pollutants reported (and their abbreviations) are 1isted in Table 21.

\begin{tabular}{ll}
\hline \multicolumn{1}{c}{ Table 21} \\
Pollutants
\end{tabular}

A number of analytic elements are involved in translating the industry-specific energy flows developed above into the array of pollutant outputs. Central factors that must be identified for each scenario year include the mix of fuels combusted for steam generation and direct heat and associated emission factors; the changes in the mix of industrial processes used to satisfy energy conservation constraints; uncontrolled emission intensities for each subprocess component; base year emission control levels; and the impact that industrial cogeneration of electricity will have on emissions. After some general comments on these points, a detailed analysis is presented below for each industry. 
A. Steam Generation and Direct Heat

Emissions from steam boilers depend strongly on fuel mix. For the base year, breakdowns of fuel input were taken from the latest BNL Reference Energy System for each industry considered. These are revisions of those used for the industrial sector of the Hittman study ${ }^{5}$ and lead to corresponding revisions of reported emission coefficients. After quantitative breakdown of fuel mix, the output of a given pollutant per ton of final product is obtained from the industrial boiler emission matrix (Table 22), which gives air emissions per $10^{6}$ Btu as a function of fuel type. Multiplication by fuel requirement to the boiler per ton of production gives the appropriate value of emissions per.ton of product. The emissions matrix used for the base year is given in Table 22 .

The emissions matrix for new plant steam boilers, a1so given in Table 22, incorporates heightened pollution control as indicated. In calculating boiler emission factors by industry, weighted averages of production by 1972 plants and new plants are needed. These are obtained by assuming a uniform $2 \%$ retirement rate of base year facilities ( $2 \%$ of the 1972 stock value) and using total output figures from the scenarios. Fractional breakdowns of new versus old production stock are presented in Table 23.

Data on emissions due to direct heat processes are available in some cases (e.g., cement) on an industry-specific basis. In cases in which data are not available (e.g;, chemicals) it has been assumed that the emission factors are the same as for steam boilers since these cases also involve direct combustion (ref. 5, p. (X-15).

The calculation of the contribution of steam boilers to industrial emission factors can be given a compact mathematical formulation. For each scenario and each year, let 
Table 22

Industrial Boiler Emission Matrix, Base Year and New Plants ${ }^{\mathrm{b}}$ (1.b/10 ${ }^{6}$ Btu)

\begin{tabular}{|c|c|c|c|c|c|c|}
\hline Fuel & Part & $\mathrm{NO}_{\mathrm{x}}$ & $\mathrm{SO}_{\mathrm{x}}^{\mathrm{C}}$ & $\mathrm{HC}$ & $\mathrm{CO}$ & Ald \\
\hline \multicolumn{7}{|l|}{ Base Year: } \\
\hline Coal & $2.48^{\mathrm{d}}$ & $5.72-1$ & 3.76 & $3.82-2$ & $7.64-2$ & $1.91-4$ \\
\hline Gas & $9.70-3$ & $1.70-1$ & $5.82-4$ & $2.91-3$ & $1.65-2$ & $9.70-5$ \\
\hline Res. oil & $1.54-1$ & $4.00-1$ & 1.59 & $2.00-2$ & $2.67-2$ & $6.68-3$ \\
\hline Dist. oil & $1.08-1$ & $4.32-1$ & $2.32-1$ & $2.16-2$ & $2 . \varepsilon \varepsilon-2$ & $1.44-2$ \\
\hline Bark/wood & 1.50 & 1.00 & $1.50-1$ & 3.60 & 3.00 & $2.50-2$ \\
\hline \multicolumn{7}{|l|}{ New plants: } \\
\hline Coal & $1.0-1$ & $5.72-1$ & $3.76-1$ & $3.82-2$ & $7.64-2$ & $1.91-4$ \\
\hline Gas & $9.7-3$ & $1.70-1$ & $5.82-4$ & $2.91-3$ & $1.65-2$ & $9.70-5$ \\
\hline Res. oil & $1.0-1$ & $3.0-1$ & $1.59-1$ & $2.00-2$ & $2.67-2$ & $6.68-3$ \\
\hline Dist. oil & $1.0-1$ & $3.0-1$ & $2.32-1$ & $2.16-2$ & $2.88-2$ & $1.44-2$ \\
\hline Bark/wood & $1.0-1$ & $3.0-1$ & $1.50-2$ & 3.60 & .3 .00 & $2.50-2$ \\
\hline
\end{tabular}

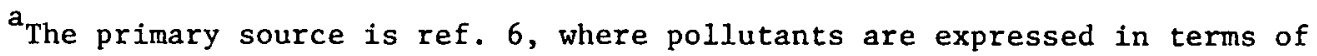
physical units of fuel input. These are converted to energy units by the factors in ref 7: coal, $26.2 \times 10^{6} \mathrm{Btu} /$ short ton; nat. gas, $1031 \mathrm{Btu} / \mathrm{ft}^{3}$ at $\mathrm{STP}$; res. oil, $6.29 \times 10^{6} \mathrm{Btu} / 42-\mathrm{gal} \mathrm{bbl}$; and dist. oil, $5.83 \mathrm{x} \cdot 10^{6} \mathrm{Btu} / 42-\mathrm{gal}$ $\mathrm{bbl}$. The factor for bark/wood is taken as $5000 \mathrm{Etu} / \mathrm{lb}$, with the assumption that the mix consists mostly of bark with a $70 \%$ moisture content, which is typical of that used in pulp mills.

${ }^{b}$ Calculations are based on $90 \%$ scrubber efficiency for so collection and on use of the lower emission factor if the 1972 factor differs ${ }^{x}$ rom EPA New Source Performance Standards (ref. 9, pp. 24878-9). The use of sciubbers with bark/wood follows from the assumption that this fuel is always burned along with coal.

${ }^{c}$ The sulfur content (from ref. 8 ) is taken to be, for coal, $2.59 \%$ (the national average); for dist. oil, $0 .-2 \%$; and for res. oil, $1.5 \%$.

${ }^{d}$ It is assumed that the ash content of. coal is $12.53 \%$, that the collection efficiency is $50 \%$, and that the particulate loading of the gases reaching control equipment is 13 times the percent ash.

Table 23

New Plant Fraction of Total Production in Five Industrial Sectors

\begin{tabular}{|c|c|c|c|c|c|c|c|c|c|}
\hline & & \multicolumn{2}{|c|}{ A } & \multicolumn{2}{|c|}{ B } & \multicolumn{2}{|c|}{ NEP } & \multicolumn{2}{|c|}{$\mathrm{SF}-2$} \\
\hline & & 1985 & 2000 & 1985 & 2000 & 1985 & 2000 & 1985 & 2000 \\
\hline \multirow[t]{2}{*}{ Pulp \& paper: } & 1972 plant & 0.53 & 0.26 & 0.53 & 0.26 & 0.49 & 0.22 & 0.49 & 0.22 \\
\hline & New plant & 0.47 & 0.74 & 0.47 & 0.74 & 0.51 & 0.78 & 0.51 & 0.78 \\
\hline \multirow[t]{2}{*}{ Primary Al: } & 1972 plant & 0.44 & 0.17 & 0.44 & 0.17 & 0.35 & 0.15 & 0.35 & 0.15 \\
\hline & New plant & 0.56 & C. 83 & 0.56 & 0.83 & 0.65 & 0.85 & 0.6 .5 & 0.85 \\
\hline \multirow[t]{2}{*}{ Iron \& steel: } & 1972 plant & 0.63 & 0.37 & 0.63 & 0.37 & 0.73 & 0.34 & 0.73 & 0.34 \\
\hline & New plant & 0.37 & 0.63 & 0.37 & 0.63 & 0.27 & 0.66 & 0.27 & 0.66 \\
\hline \multirow[t]{2}{*}{ Cement: } & 1972 plant & 0.63 & 0.36 & 0.63 & 0.36 & 0.47 & 0.20 & 0.47 & 0.20 \\
\hline & New Plant & 0.37 & 0.64 & 0.37 & 0.64 & 0.53 & $0.80^{\circ}$ & 0.53 & 0.80 \\
\hline \multirow[t]{2}{*}{ Chemicals: } & 1972 plant & 0.48 & 0.21 & 0.48 & 0.21 & 0.51 & 0.21 & 0.57 & 0.22 \\
\hline & New plant & 0.52 & 0.79 & 0.52 & 0.79 & 0.49 & 0.79 & 0.43 & 0.78 \\
\hline
\end{tabular}


$P_{i}^{A}$ be the emission of pollutant $i$ in $1 b /$ short ton product for industry $A$, $\mathrm{F}_{\mathrm{J}}^{\mathrm{A}}$ be the energy input of fuel $\mathrm{j}$ in $10^{6} \mathrm{Btu} /$ short ton product, $e_{i j}$ be the emission of pollutant $i$ due to combustion of fuel $j$ in $1 \mathrm{~b} / 10^{6}$ Btu at base-year control levels,

$e_{i j}^{\prime}$ be the emission of pollutant $i$ in $1 \mathrm{~b} / 10^{6}$ Btu due to combustion of fuel $j$ at new-plant control levels and,

$\mathrm{f}^{\mathrm{A}}$ and $\mathrm{f}^{\prime A}$ be the fraction of production at base-year and new-plant contro1 levels in industry $\mathrm{A}$.

Then,

$$
\begin{aligned}
& P_{i}^{A}=\underset{f u e l s}{\Sigma} F_{j}^{A}\left(f^{A} e_{i j}+f^{\prime A} \cdot e_{i j}^{\prime}\right) \text { +non-boiler-related contributions (IV-a) } \\
& P_{i}^{A}=\underset{f u e l s}{\sum} F_{j}^{A}\left(f^{A} e_{i j}+f^{\prime A} e_{i j}^{\prime}\right)+\text { non-boiler-related contributions } .(1)
\end{aligned}
$$

B. Changes in Process Mix

Each scenario implies a constraint upon energy input and product output. In matching energy to output, shifts have been assumed in the relative shares of alternative processes. For example, for cement the relatively energy conserving dry process is assumed to account for a larger fraction of production in some cases. Other shifts in process mix have been assumed as industrial sectors adjust to economic and environmental imperatives. An example of the latter is found in primary aluminum production, for which potroom emission control levels required by EPA standards imply that future facilities will not utilize the Soderberg reduction cell. However, the relative economic attractiveness of the various conservation options was not analyzed in this study. 


\section{Process Emissions}

Since average emission factors depend on the relative shares of various process options for each industry, it was necessary to use disaggregated estimates of emission factors by process as opposed to the gross average estimates presented, for example, by Hittman. ${ }^{5}$ The process contribution to emission factors can then be quantified for a given scenario year by taking weighted averages over the scenario-specific process mix. Furthermore, changes in base-year emission levels due to intensified environmental controls in new plants are defined and phased in on the basis of the fractional breakdowns of old and new facilities given in Table 23.

More precisely, if $p_{i}^{A}$ and $p_{i}^{\prime}$ are the process-related emissions from baseyear control level facilities and new-plant control level facilities, respectively, for industry $A$ and pollutant $i$, then

$$
P_{i}^{A}=f^{A} P_{i}^{A}+F^{\prime A} P_{i}^{\prime A}+\text { non-process-related contributions } \cdot(I V-b)
$$

\section{Cogeneration}

Three factors determine the environmental impact of new cogeneration: the kinds and amounts of fuels used for the cogeneration of electricity and steam; the corresponding emission factors by fuel; and the emission credit at the utility due to lowered demands on centralized electric power production.

The fuel mix used in cogeneration has been designated above by industry and by scenario. The emission factors for gas turbine topping cycles that have been assumed for new cogeneration are given in Table 24 .

In calculating cogeneration-related utility emission credits, emission factors given in ref. 5 (Sec. VI) for controlled plants are used. The corresponding emissions matrix is given in Table 25. 
Table 24

Cogeneration Emission Coefficients, Gas Turbine Topping* ( $\left.1 \mathrm{~b} / 10^{6} \mathrm{Btu}\right)$

\begin{tabular}{lccccc}
\hline Fuel & Part & NO & SO & HC & CO \\
\hline Dist. oil & $3.60-2$ & $4.88-1$ & $2.26-1$ & $4.01-2$ & $1.11-1$ \\
Nat. gas & $1.36-2$ & $4.01-1$ & $9.40-3$ & $4.07-2$ & $1.12-1$ \\
Coal** & $1.00-1$ & $5.72-1$ & $3.76-1$ & $3.82-2$ & $7.6 .4-2$ \\
\hline
\end{tabular}

*From ref. 6, App. C, F. 6, with previous assumptions about conversions and about ash and sulfur contents. Note that -2 means x $10^{-2}$.

**Assumed to be controlled to coal-fired boller New Source Performance Standards.

Table 25

Electric Power Plant Emissions Matrix $\left(1 \mathrm{~b} / 10^{6} \mathrm{Btu}\right)$

\begin{tabular}{llllllll}
\hline Fuel & Part & NO & SO & HC & CO & Ald & TS \\
\hline Coal & $4.12-2$ & $7.38-1$ & $4.04-1$ & $1.23-2$ & $4.10-2$ & $2.6-4$ & $3.6-2$ \\
Oil & $5.44-2$ & $7.14-1$ & $6.40-1$ & $1.36-2$ & $2.76-4$ & $6.8-3$ & $6.8-3$ \\
Gas & $1.47-2$ & $3.82-1$ & $5.86-4$ & $3.92-2$ & $3.80-4$ & $6.83-3$ & $6.8-3$ \\
\hline
\end{tabular}


The net contribution from cogeneration can be calculated as follows. Let

$\mathrm{PC}_{i}^{\mathrm{A}}$ be the net emission of pollutant $i$ in $1 \mathrm{~b} /$ short ton product due to cogeneration in industry $\mathrm{A}$,

$G_{j}^{A}$ be the energy input of fuel $j$ to gas turbine topping units in $10^{6}$ Btu/ short ton product,

$U_{j}^{A}$ be the utility energy credit in $10^{6} \mathrm{Btu} /$ short ton product, and

$c_{i j}$ and $d_{i j}$ be the emissions matrices in $1 b / 10^{6}$ Btu for gas turbines and utilities, respectively.

Then,

$$
P C_{i}^{A}=\underset{\text { fuels }}{\Sigma}\left(G_{j}^{A} c_{i j}-U_{j}^{A} d_{i j}\right)
$$

Combining the various contributions leads to the master equation:

$P_{i}^{A}=\underset{f u e l s}{\Sigma} F_{j}^{A}\left(f^{A} e_{i j}+f^{\prime A} e^{\prime}{ }_{i j}\right)+f^{A} p_{i}^{A}+f^{\prime A} p_{i}^{\prime A}+\underset{f u e l s}{\Sigma}\left(C_{j}^{A} c_{i j}-U_{j}^{A} d_{i j}\right)$

which gives the emission of pollutants in $1 \mathrm{~b} /$ short ton product from industry

A. Of ten boiler and process contributions for old and new plants are calculated together as an intermediate step, which makes the following form of Eq. (4) convenient:

$\mathrm{P}_{i}^{A}=\mathrm{f}^{\mathrm{A}} \underset{\text { fuels }}{\Sigma}\left(e_{i j} \vec{F}_{j}^{A}+p_{i}^{A}\right)+f^{\prime A} \underset{\text { fuels }}{\Sigma}\left(e_{i j}^{\prime} F_{j}^{A}+p_{i}^{\prime A}\right)+$ cogeneration contribution.

Note that in some cases $\mathrm{P}_{i}^{\mathrm{A}}$ may be negative.

In summary, the contributions to emission factors from steam boilers and direct heat, from processes, and from cogeneration are dependent on fuel mixes, process shifts, control levels, and cogeneration penetration specific to each scenario and year. These general considerations were applied to five central industries to generate emission factors for each scenario year being studied. 
E. Pulp and Paper

The energy flows were specified in Table 13. Process air emissions are given in Table 26 along with boiler emissions for the 1972 fuel mix. The emission data for untreated processes are from the EPA. ${ }^{6}$ As in the Hittman report, ${ }^{5}$ the Kraft process, which accounts for 80 to $85 \%$ of production, is assumed to represent the industry. However, whereas Hittman arbitrarily assumes emission control technologies such as Venturi scrubbers for recovery boilers, the data in Table 26 are based on EPA ${ }^{10}$ average industry control levels for base-year and new facilities.

Emission factors for water pollutants are given in Table 27. Base-year levels are from Hittman, ${ }^{5}$ and new-plant control levels are taken as "best technology economically achievable" levels (ref. 11, Water Reg. 748-5).

From the data in Tables 26 and 27, and boiler emission matrices (Table 22), emissions from new and in-place plants can be evaluated. These, along with cogeneration contributions calculated from Eq. (3), are entered for each scenario in Table 28. Finally, use of the pulp and paper data in Table 23 to take weighted averages of new and base-year plant contributions leads to the summary emission factors at the end of Table 28 .

F. Primary Aluminum

Base-year primary aluminum air emissions for unit processes are summarized in Table 29. Reductions from untreated levels are based on the Hitman ${ }^{5}$ control assumptions, except for potroom average control efficiencies, which are based on EPA $^{12}$ estimates. Fuel mix to 1972 boilers is from Table 15.

Air emission factors are scenario dependent in four basic ways: (1) Boiler emissions are functions of fuel mix and fractional breakdown of base-year and 


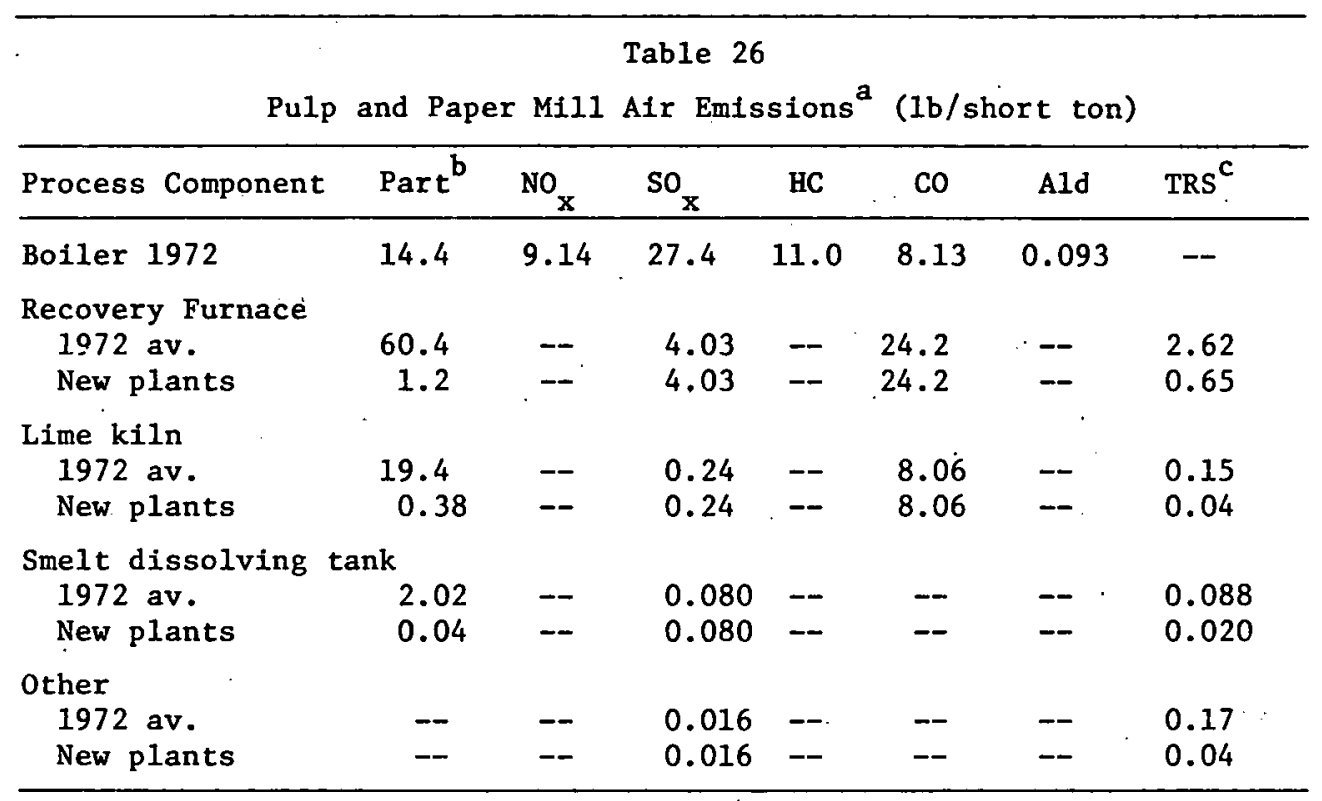

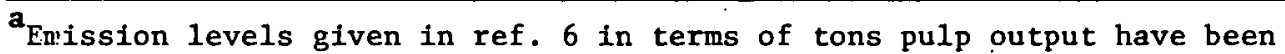
converted on the basis of 1 ton pulp for each 1.24 tons paper product. b Assume reduction in particulates from 1972 untreated levels to be $50 \%$ overall and $99 \%$ for new plants. 10

CAssumes level of total sulfur to be $25 \%$ of uncontrolled levels overall and $5 \%$ of uncontrolled levels for new plants. 10

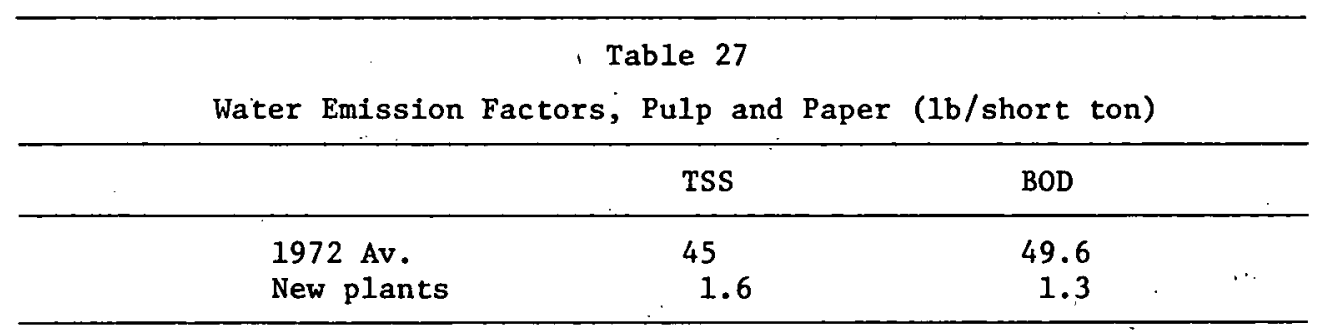


l'able 28

Pulp and Paper Mill Emissions by Scenario (1b/short ton)

(B\&P = boiler and process)

\begin{tabular}{|c|c|c|c|c|c|c|c|c|c|c|}
\hline Scenario & & Part & ${ }^{\text {NO }}{ }_{x}$ & $\mathrm{SO}_{\mathrm{x}}$ & $\mathrm{HC}$ & $\mathrm{CO}$ & Ald & TRS & TSS & BOD \\
\hline A, 1985 & $\begin{array}{r}\text { B\&P: } 1972 \text { plants } \\
\text { New plants } \\
\text { New cogeneration }\end{array}$ & $\begin{array}{l}96.0 \\
3.00 \\
0.450\end{array}$ & $\begin{array}{l}7.66 \\
4.66 \\
1.87\end{array}$ & $\begin{array}{l}23.5 \\
6.32 \\
1.30\end{array}$ & $\begin{array}{l}13.5 \\
13.5 \\
-0.18\end{array}$ & $\begin{array}{l}43.8 \\
43.8 \\
0.385\end{array}$ & $\begin{array}{l}0.122 \\
0.122 \\
--\end{array}$ & $\begin{array}{l}3.03 \\
0.50 \\
--\end{array}$ & $\begin{array}{c}45.0 \\
1.6 \\
-0.012\end{array}$ & $\begin{array}{r}49.6 \\
1.3 \\
--\end{array}$ \\
\hline A, 2000 & $\begin{array}{r}\text { B\&P: } 1972 \text { plants } \\
\text { New plants } \\
\text { New cogeneration }\end{array}$ & $\begin{array}{l}96.0 \\
2.63 \\
0.902\end{array}$ & $\begin{array}{l}6.43 \\
2.93 \\
3.74\end{array}$ & $\begin{array}{l}14.6 \\
5.42 \\
2.60\end{array}$ & $\begin{array}{l}18.1 \\
18.1 \\
-0.36\end{array}$ & $\begin{aligned} 47.5 \\
47.5 \\
0.760\end{aligned}$ & $\begin{array}{l}0.128 \\
0.128 \\
--\end{array}$ & $\begin{array}{l}3.03 \\
0.50 \\
--\end{array}$ & $\begin{array}{l}45.0 \\
1.6 \\
-0.024\end{array}$ & $\begin{array}{r}49.6 \\
1.3 \\
--\end{array}$ \\
\hline$B, 1985$ & $\begin{array}{r}\text { B\&P: } 1972 \text { plants } \\
\text { New plants } \\
\text { New cogeneration }\end{array}$ & $\begin{array}{l}95.3 \\
2.99 \\
0.450\end{array}$ & $\begin{array}{l}7.26 \\
4.74 \\
2.07\end{array}$ & $\begin{array}{r}24.9 \\
6.31 \\
1.41\end{array}$ & $\begin{array}{l}11.7 \\
11.7 \\
-0.741\end{array}$ & $\begin{array}{l}42.3 \\
42.3 \\
0.404\end{array}$ & $\begin{array}{l}0.109 \\
0.109 \\
-\end{array}$ & $\begin{array}{l}3.03 \\
0.50 \\
--\end{array}$ & $\begin{array}{l}45.0 \\
3.03 \\
-0.010\end{array}$ & $\begin{array}{r}49.6 \\
1.3 \\
--\end{array}$ \\
\hline B, 2000 & $\begin{array}{r}\text { B\&P : } 1972 \text { plants } \\
\text { New plants } \\
\text { New cogeneration }\end{array}$ & $\begin{array}{l}96.2 \\
2.62 \\
0.900\end{array}$ & $\begin{array}{l}5.94 \\
3.14 \\
4.14\end{array}$ & $\begin{array}{r}17.8 \\
5.74 \\
2.82\end{array}$ & $\begin{array}{l}14.5 \\
14.5 \\
-1.48\end{array}$ & $\begin{array}{l}45.3 \\
45.3 \\
0.808\end{array}$ & $\begin{array}{l}0.102 \\
0.102 \\
--\end{array}$ & $\begin{array}{l}3.03 \\
0.50 \\
--\end{array}$ & $\begin{array}{r}45.0 \\
3.03 \\
-0.20\end{array}$ & $\begin{array}{r}49.6 \\
1.3 \\
--\end{array}$ \\
\hline NEP, & $\begin{array}{r}\text { B\&P : } 1972 \text { plants } \\
\text { New plants } \\
\text { New cogeneration }\end{array}$ & $\begin{array}{c}110.8 \\
3.52 \\
--\end{array}$ & $\begin{array}{c}11.42 \\
7.94 \\
--\end{array}$ & $\begin{array}{c}47.0 \\
8.67 \\
--\end{array}$ & $\begin{array}{l}9.45 \\
9.45 \\
--\end{array}$ & $\begin{array}{c}40.7 \\
40.7 \\
--\end{array}$ & $\begin{array}{c}0.092 \\
0.092 \\
-\end{array}$ & $\begin{array}{l}3.03 \\
0.50 \\
--\end{array}$ & $\begin{array}{l}45.0 \\
1.6 \\
--\end{array}$ & $\begin{array}{r}49.6 \\
1.3 \\
-\end{array}$ \\
\hline NEP, 2000 & $\begin{array}{r}\text { B\&P: } 1972 \text { plants } \\
\text { New plants } \\
\text { New cogeneration }\end{array}$ & $\begin{array}{c}123.5 \\
3.66 \\
--\end{array}$ & $\begin{array}{c}11.3 \\
9.52 \\
--\end{array}$ & $\begin{array}{c}62.3 \\
10.2 \\
--\end{array}$ & $\begin{array}{l}9.58 \\
9.58 \\
--\end{array}$ & $\begin{array}{c}41.0 \\
41.0 \\
--\end{array}$ & $\begin{array}{l}0.065 \\
0.065 \\
--\end{array}$ & $\begin{array}{l}3.03 \\
0.50 \\
--\end{array}$ & $\begin{array}{c}45.0 \\
1.6 \\
--\end{array}$ & $\begin{array}{r}49.6 \\
1.3 \\
--\end{array}$ \\
\hline$\underline{\mathrm{SF}-2, \quad 1985}$ & $\begin{array}{r}\text { B\&P: } 1972 \text { plants } \\
\text { New plants } \\
\text { New cogeneration }\end{array}$ & $\begin{array}{c}108.5 \\
3.57 \\
--\end{array}$ & $\begin{array}{c}11.9 \\
9.66 \\
--\end{array}$ & $\begin{array}{l}46.5 \\
8.62 \\
--\end{array}$ & $\begin{array}{l}9.45 \\
9.45 \\
--\end{array}$ & $\begin{array}{c}40.7 \\
40.7 \\
--\end{array}$ & $\begin{array}{c}0.099 \\
0.099 \\
--\end{array}$ & $\begin{array}{l}3.03 \\
0.50 \\
-\end{array}$ & $\begin{array}{l}45.0 \\
1.6 \\
--\end{array}$ & $\begin{array}{r}49.6 \\
1.3 \\
--\end{array}$ \\
\hline$\underline{S E-2,} 2000$ & $\begin{array}{r}\text { B\&P: } 1972 \text { plants } \\
\text { New plants } \\
\text { New cogeneration }\end{array}$ & $\begin{array}{c}120.8 \\
3.75 \\
--\end{array}$ & $\begin{array}{c}11.4 \\
9.48 \\
--\end{array}$ & $\begin{array}{c}61.1 \\
10.1 \\
--\end{array}$ & $\begin{array}{l}9.58 \\
9.58 \\
--\end{array}$ & $\begin{array}{c}40.9 \\
40.9 \\
--\end{array}$ & $\begin{array}{l}0.079 \\
0.079 \\
--\end{array}$ & $\begin{array}{l}3.03 \\
0.50 \\
-\end{array}$ & $\begin{array}{c}45.0 \\
1.6 \\
--\end{array}$ & $\begin{array}{r}49.6 \\
1.3 \\
--\end{array}$ \\
\hline Summary & 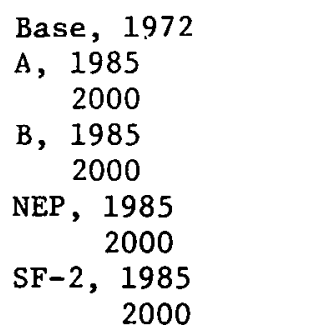 & $\begin{array}{l}96.2 \\
52.7 \\
27.8 \\
52.4 \\
27.8 \\
56.1 \\
30.0 \\
55.0 \\
29.5\end{array}$ & $\begin{array}{c}9.14 \\
8.12 \\
7.58 \\
8.15 \\
8.01 \\
9.65 \\
9.91 \\
10.8 \\
9.90\end{array}$ & $\begin{array}{l}31.8 \\
16.7 \\
10.4 \\
17.6 \\
11.7 \\
27.5 \\
21.7 \\
27.2 \\
21.3\end{array}$ & $\begin{array}{c}11.0 \\
13.3 \\
17.7 \\
11.0 \\
14.4 \\
9.45 \\
9.58 \\
9.45 \\
9.58\end{array}$ & $\begin{array}{l}40.4 \\
43.5 \\
46.7 \\
42.7 \\
46.1 \\
40.7 \\
41.0 \\
40.7 \\
40.9\end{array}$ & $\begin{array}{l}0.093 \\
0.122 \\
0.128 \\
0.109 \\
0.102 \\
0.092 \\
0.065 \\
0.099 \\
0.079\end{array}$ & $\begin{array}{l}3.03 \\
1.84 \\
1.14 \\
1.84 \\
1.14 \\
1.71 \\
1.05 \\
1.71 \\
1.05\end{array}$ & $\begin{array}{l}45.0 \\
24.6 \\
12.9 \\
24.6 \\
12.9 \\
22.9 \\
11.2 \\
22.9 \\
11.2\end{array}$ & $\begin{array}{l}49.6 \\
26.9 \\
13.9 \\
26.9 \\
13.9 \\
25.0 \\
11.9 \\
25.0 \\
11.9\end{array}$ \\
\hline
\end{tabular}




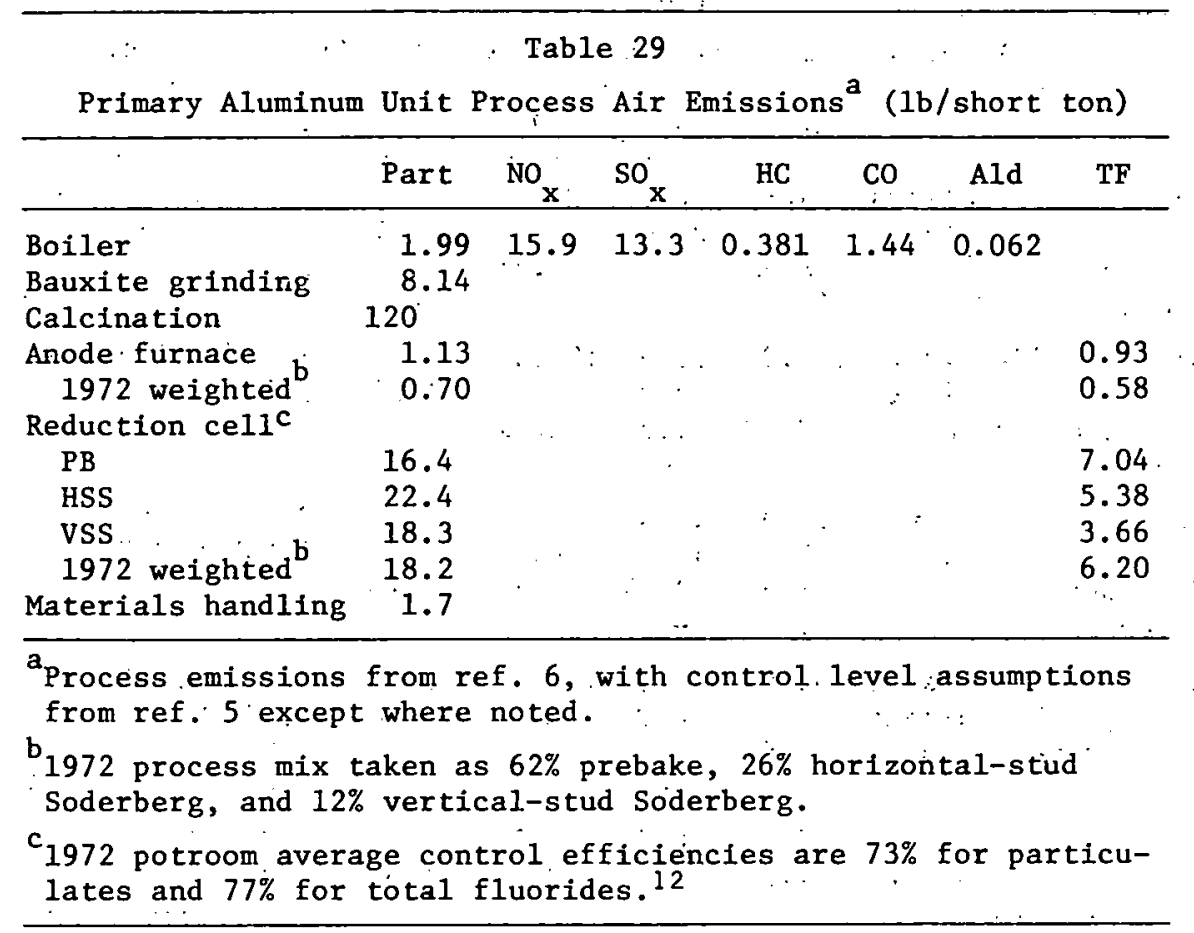

new plants (see Table 23). (2) New plant fluoride emissions are phased in at the EPA standard of two pounds per ton product (ref. 10, Air Reg. 49). (3) Different levels of cogeneration are involved. (4) Particulate and fluoride emissions from reduction cells are dependent on the process mix assumed. For instance, it has been assumed that no new. Soderberg cell reduction units will be installed because they cannot economically meet EPA fluoride emission standards, ${ }^{13}$ and that process emissions for the fraction of production allotted to the new Alcoa process will be insignificant.

The water emission levels available are from Hittman. ${ }^{5}$ Breakdowns of emissions by scenario and year are given in Table 30 . Finally, total emission factors calculated by using Eq. (5) are summarized at the end of Table 30 . 
Table 30

Primary Aluminum Plant Emissions by Scenario (lb/short ton)

\begin{tabular}{|c|c|c|c|c|c|c|c|c|c|c|}
\hline Scenario & & Part & ${ }^{\text {NO }} x$ & ${ }^{\mathrm{SO}} \mathrm{x}$ & $\mathrm{HC}$ & $\mathrm{CO}$ & AId & TF & TStorg & BOD \\
\hline A, 1985 & $\begin{array}{l}\text { Boiler: } 1972 \text { plants } \\
\text { New plants } \\
\text { New cogeneration } \\
\text { Process }\end{array}$ & $\begin{array}{r}63.1 \\
3.42 \\
1.35 \\
141\end{array}$ & $\begin{array}{l}22.6 \\
22.0 \\
1.27 \\
--\end{array}$ & $\begin{array}{c}103.0 \\
10.3 \\
1.41 \\
--\end{array}$ & $\begin{array}{l}1.17 \\
1.17 \\
0.743 \\
--\end{array}$ & $\begin{array}{l}2.64 \\
2.64 \\
1.08 \\
--\end{array}$ & $\begin{array}{r}0.047 \\
0.047 \\
-0.004 \\
---\end{array}$ & $\begin{array}{l}-- \\
-- \\
-- \\
3.26\end{array}$ & $\begin{array}{l}-- \\
-- \\
-0.587 \\
14.5\end{array}$ & $\begin{array}{l}-- \\
-- \\
-- \\
0.19\end{array}$ \\
\hline$A, 2000$ & $\begin{array}{l}\text { Boiler: } 1972 \text { plants } \\
\text { New plants } \\
\text { New cogeneration } \\
\text { Process }\end{array}$ & $\begin{array}{r}123.0 \\
4.96 \\
2.70 \\
131\end{array}$ & $\begin{array}{l}28.4 \\
28.4 \\
2.54 \\
--\end{array}$ & $\begin{array}{c}186.5 \\
18.7 \\
2.81 \\
--\end{array}$ & $\begin{array}{l}1.89 \\
1.89 \\
1.48 \\
--\end{array}$ & $\begin{array}{l}3.79 \\
3.79 \\
2.16 \\
--\end{array}$ & $\begin{array}{r}0.010 \\
0.010 \\
-0.008 \\
--\end{array}$ & $\begin{array}{l}-- \\
-- \\
-- \\
0.67\end{array}$ & $\begin{array}{l}-- \\
-- \\
-1.17 \\
1.5\end{array}$ & $\begin{array}{l}-- \\
-- \\
-- \\
0.032\end{array}$ \\
\hline B, 1985 & $\begin{array}{l}\text { Boiler: } 1972 \text { plants } \\
\text { New plante } \\
\text { New cogeneration } \\
\text { Process }\end{array}$ & $\begin{array}{c}53.3 \\
2.94 \\
1.31 \\
141\end{array}$ & $\begin{array}{l}20.4 \\
19.7 \\
1.27 \\
--\end{array}$ & $\begin{array}{l}88.0 \\
8.81 \\
1.37 \\
--\end{array}$ & $\begin{array}{l}1.02 \\
1.02 \\
.709 \\
--\end{array}$ & $\begin{array}{l}2.34 \\
2.34 \\
1.41 \\
--\end{array}$ & $\begin{array}{r}0.047 \\
0.047 \\
-0.004 \\
--\end{array}$ & $\begin{array}{l}-- \\
-- \\
-- \\
3.26\end{array}$ & $\begin{array}{l}-- \\
-0.587 \\
14.5\end{array}$ & $\begin{array}{l}-- \\
-- \\
0.19\end{array}$ \\
\hline B, 2000 & $\begin{array}{l}\text { Boiler: } 1972 \text { plants } \\
\text { New plants } \\
\text { New cogeneration } \\
\text { Process }\end{array}$ & $\begin{array}{r}103.9 \\
4.19 \\
2.61 \\
131\end{array}$ & $\begin{array}{l}24.0 \\
24.0 \\
2.54 \\
--\end{array}$ & $\begin{array}{c}157.5 \\
15.8 \\
2.74 \\
--\end{array}$ & $\begin{array}{l}1.60 \\
1.60 \\
1.41 \\
--\end{array}$ & $\begin{array}{l}3.20 \\
3.20 \\
2.82 \\
--\end{array}$ & $\begin{array}{r}0.008 \\
0.008 \\
-0.008 \\
--\end{array}$ & $\begin{array}{c}-- \\
-- \\
-- \\
0.67\end{array}$ & $\begin{array}{l}-- \\
-1.17 \\
1.5\end{array}$ & $\begin{array}{l}-- \\
-- \\
-- \\
0.032\end{array}$ \\
\hline NEP， 1985 & $\begin{array}{l}\text { Boiler: } 1972 \text { plants } \\
\text { New plants } \\
\text { New cogeneration } \\
\text { Process }\end{array}$ & $\begin{array}{c}85.1 \\
4.34 \\
-- \\
142\end{array}$ & $\begin{array}{c}28.2 \\
27.7 \\
-- \\
--\end{array}$ & $\begin{array}{c}136.5 \\
13.7 \\
-- \\
--\end{array}$ & $\begin{array}{l}1.52 \\
1.52 \\
-- \\
--\end{array}$ & $\begin{array}{l}3.37 \\
3.37 \\
-- \\
--\end{array}$ & $\begin{array}{l}0.050 \\
0.050 \\
-- \\
--\end{array}$ & $\begin{array}{l}-- \\
-- \\
-- \\
2.97\end{array}$ & $\begin{array}{c}-- \\
-- \\
-- \\
16.3\end{array}$ & $\begin{array}{l}-- \\
-- \\
-- \\
0.19\end{array}$ \\
\hline NEP, 2000 & 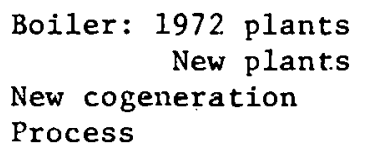 & $\begin{array}{c}168.2 \\
6.84 \\
=- \\
134\end{array}$ & $\begin{array}{c}29.9 \\
39.9 \\
-- \\
--\end{array}$ & $\begin{array}{c}255 \\
25.5 \\
-- \\
--\end{array}$ & $\begin{array}{c}2.61 \\
2.61 \\
-- \\
--\end{array}$ & $\begin{array}{l}5.29 \\
5.29 \\
-- \\
--\end{array}$ & $\begin{array}{l}0.0135 \\
0.014 \\
-- \\
--\end{array}$ & $\begin{array}{l}-- \\
-- \\
--22\end{array}$ & $\begin{array}{l}-- \\
-- \\
-- \\
6.25\end{array}$ & $\begin{array}{l}-- \\
-- \\
-- \\
0.032\end{array}$ \\
\hline$\underline{S F-2,1985}$ & $\begin{array}{l}\text { Boiler: } 1972 \text { plants } \\
\text { New plants } \\
\text { New cogeneration } \\
\text { Process }\end{array}$ & $\begin{array}{c}54.0 \\
3.20 \\
-- \\
148\end{array}$ & $\begin{array}{c}23.1 \\
22.5 \\
-- \\
--\end{array}$ & $\begin{array}{l}89.1 \\
8.94 \\
-- \\
--\end{array}$ & $\begin{array}{c}1.08 \\
1.08 \\
-- \\
--\end{array}$ & $\begin{array}{c}2.61 \\
2.61 \\
-- \\
--\end{array}$ & $\begin{array}{l}0.05 \\
0.05 \\
-- \\
--\end{array}$ & $\begin{array}{l}-- \\
-- \\
-- \\
3.67\end{array}$ & $\begin{array}{l}-- \\
-- \\
--\end{array}$ & $\begin{array}{l}-- \\
-- \\
0.19\end{array}$ \\
\hline$S F-2,2000$ & $\begin{array}{l}\text { Boiler: } 1972 \text { plants } \\
\text { New plants } \\
\text { New cogeneration } \\
\text { Process }\end{array}$ & $\begin{array}{c}105.2 \\
4.52 \\
-- \\
147\end{array}$ & $\begin{array}{l}29.4 \\
29.4 \\
-- \\
--\end{array}$ & $\begin{array}{c}159.1 \\
15.9 \\
-- \\
--\end{array}$ & $\begin{array}{l}1.70 \\
1.70 \\
-- \\
--\end{array}$ & $\begin{array}{l}3.73 \\
3.73 \\
-- \\
--\end{array}$ & $\begin{array}{c}0.01 \\
0.01 \\
-- \\
--\end{array}$ & $\begin{array}{l}-- \\
-- \\
-- \\
2.72\end{array}$ & $\begin{array}{l}-- \\
-- \\
25\end{array}$ & $\begin{array}{l}-- \\
-- \\
-\infty \\
0.032\end{array}$ \\
\hline Sumnary & $\begin{array}{c}\text { Base, } 1972 \\
\text { A, } 1985 \\
2000 \\
\text { B, } 1985 \\
2000 \\
\text { NEP, } 1985 \\
2000 \\
\text { SF-2, } \begin{array}{l}1985 \\
2000\end{array}\end{array}$ & $\begin{array}{l}150 \\
172 \\
159 \\
167 \\
155 \\
175 \\
165 \\
169 \\
166\end{array}$ & $\begin{array}{l}15.9 \\
23.5 \\
30.9 \\
21.2 \\
26.5 \\
27.9 \\
38.4 \\
22.7 \\
29.4\end{array}$ & $\begin{array}{l}13.3 \\
57.6 \\
50.0 \\
45.0 \\
42.6 \\
56.7 \\
59.9 \\
37.0 \\
37.4\end{array}$ & $\begin{array}{l}0.381 \\
1.91 \\
3.37 \\
1.73 \\
3.01 \\
1.52 \\
2.61 \\
1.08 \\
1.70\end{array}$ & $\begin{array}{l}1.44 \\
3.72 \\
5.95 \\
3.75 \\
6.02 \\
3.37 \\
5.29 \\
2.61 \\
3.73\end{array}$ & $\begin{array}{c}0.062 \\
0.043 \\
-0.002 \\
0.043 \\
-- \\
0.050 \\
0.014 \\
0.05 \\
0.01\end{array}$ & $\begin{array}{l}6.78 \\
3.26 \\
0.67 \\
3.26 \\
0.67 \\
2.97 \\
1.22 \\
3.67 \\
2.72\end{array}$ & $\begin{array}{c}25 \\
13.9 \\
0.33 \\
13.9 \\
0.33 \\
16.3 \\
6.25 \\
25 \\
25\end{array}$ & $\begin{array}{l}0.32 \\
0.19 \\
0.032 \\
0.19 \\
0.032 \\
0.21 \\
0.081 \\
0.32 \\
0.32\end{array}$ \\
\hline
\end{tabular}


G. Iron and Stee1

As with the paper and aluminum industries, scenario emissions are sensitive to fuel mix, process mix and cogeneration level. Process air emissions based on EPA $^{6}$ data are given in Table 31 , with control levels from Hitman ${ }^{5}$ and other assumptions listed in footnotes. Aggregate water emissions already incorporate EPA treatment levels (ref. 6, P. IX-30). Process breakdown of water emissions are taken from EPA New Source Performance Standards (ref. 11, Water Reg. 795-97).

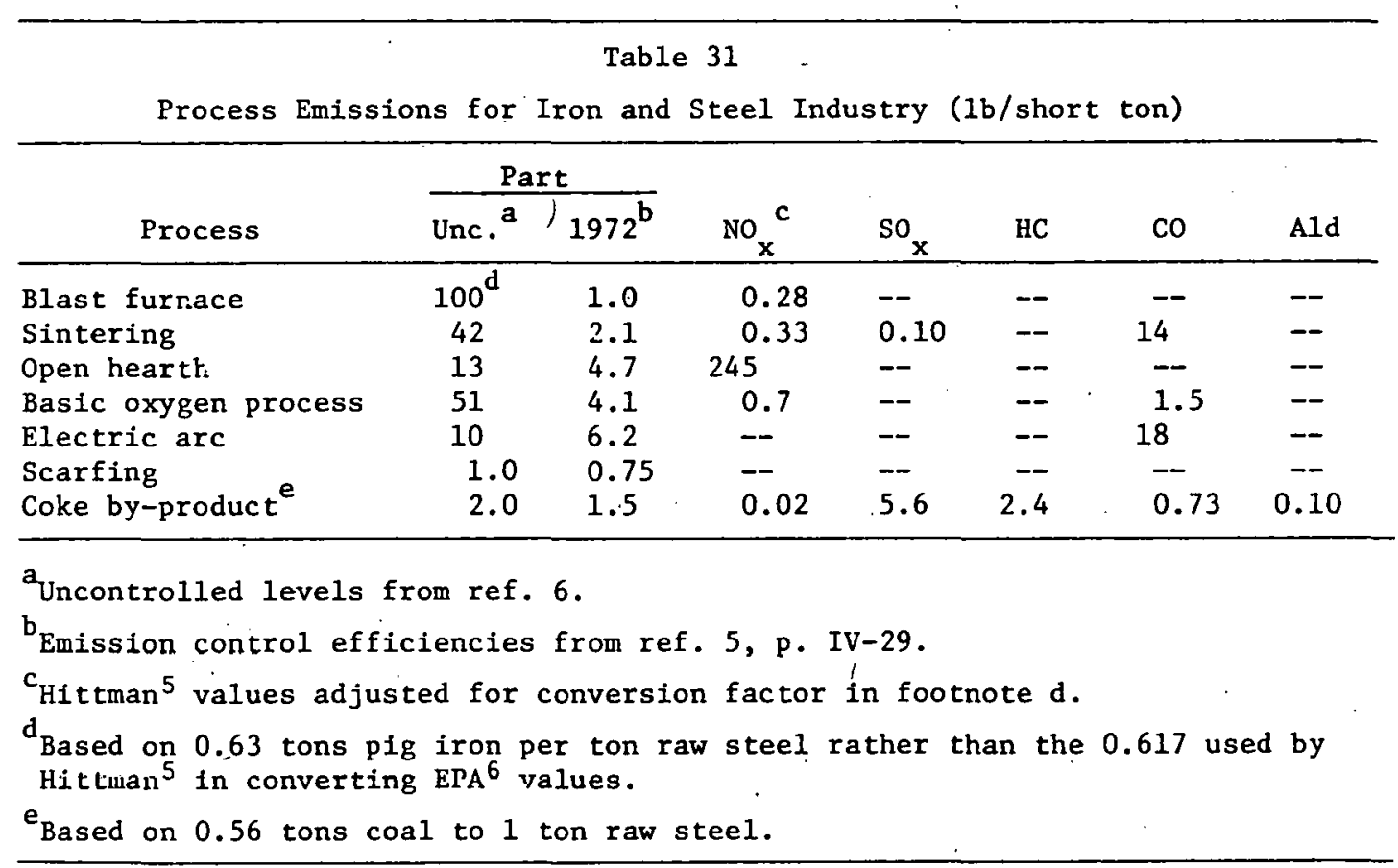

In Table 32, emission factors are given for each scenario. Boiler emissions are based on the fuel mixes of Table 10 and Eq. (1). The percent breakdown of furnace technologies used in calculating process emission contributions is indicated in each case. Net cogeneration contributions are calculated from Eq. (3). Total emissions are summarized at the end of Table 32. 
Táble 32

Iron and Stee1. Mill Emissions by Scenario (1b/short ton)

\begin{tabular}{|c|c|c|c|c|c|c|c|c|c|}
\hline Scenar1o & & Part & $\mathrm{NO}_{x}$ & $\mathrm{SO}_{\mathrm{x}}$ & $\mathrm{HC}$ & $\mathrm{CO}$ & Ald & TSS & Org \\
\hline A, 1985 & $\begin{array}{l}\text { Process* } \\
\text { Boiler } \\
\text { Cogeneration }\end{array}$ & $\begin{array}{l}9.92 \\
0.39 \\
0.01\end{array}$ & $\begin{array}{l}41.8 \\
0.35 \\
-0.69\end{array}$ & $\begin{array}{r}5.70 \\
0.58 \\
-0.60\end{array}$ & $\begin{array}{l}2.40 \\
0.018 \\
-0.0070\end{array}$ & $\begin{array}{l}19.1 \\
0.040 \\
0.25\end{array}$ & $\begin{array}{l}0.10 \\
0.0012 \\
-0.013\end{array}$ & $\begin{array}{c}1.59 \\
-0.013\end{array}$ & $\begin{array}{l}1.09 \\
-- \\
--\end{array}$ \\
\hline A, 2000 & $\begin{array}{l}\text { Process } \\
\text { Boiler } \\
\text { Cogeneration }\end{array}$ & $\begin{array}{c}9.80 \\
-- \\
0.02\end{array}$ & $\begin{array}{c}24.9 \\
-- \\
-1.38\end{array}$ & $\begin{array}{c}5.70 \\
-- \\
-1.20\end{array}$ & $\begin{array}{c}2.40 \\
-- \\
-0.014\end{array}$ & $\begin{array}{c}19.1 \\
0.50\end{array}$ & $\begin{array}{c}1.00 \\
-- \\
-0.026\end{array}$ & $\begin{array}{c}1.00 \\
-0.026\end{array}$ & $\begin{array}{c}1.01 \\
-- \\
--\end{array}$ \\
\hline B, 1985 & $\begin{array}{l}\text { Process* } \\
\text { Boiler } \\
\text { Cogeneration }\end{array}$ & $\begin{array}{l}9.92 \\
0.39 \\
0.01\end{array}$ & $\begin{array}{r}42.0 \\
0.35 \\
-0.54\end{array}$ & $\begin{array}{r}5.70 \\
0.58 \\
-0.50\end{array}$ & $\begin{array}{r}2.40 \\
0.018 \\
-0.003\end{array}$ & $\begin{array}{l}19.1 \\
0.040 \\
0.27\end{array}$ & $\begin{array}{l}0.10 \\
0.0012 \\
-0.013\end{array}$ & $\begin{array}{c}1.59 \\
-- \\
-0.013\end{array}$ & $\begin{array}{c}1.09 \\
-- \\
--\end{array}$ \\
\hline $\mathrm{B}, 2000$ & $\begin{array}{l}\text { Process* } \\
\text { Boiler } \\
\text { Cogeneration. }\end{array}$ & $\begin{array}{l}9.8 \\
-- \\
0.02\end{array}$ & $\begin{array}{c}24.9 \\
-- \\
-1.08\end{array}$ & $\begin{array}{c}5.70 \\
-- \\
-1.00\end{array}$ & $\begin{array}{c}2.40 \\
-0.006\end{array}$ & $\begin{array}{c}19.1 \\
-- \\
0.54\end{array}$ & $\begin{array}{c}0.10 \\
-- \\
-0.026\end{array}$ & $\begin{array}{c}1.00 \\
-- \\
-0.026\end{array}$ & $\begin{array}{c}1.01 \\
-- \\
--\end{array}$ \\
\hline NEP, 1985 & $\begin{array}{l}\text { Process } \\
\text { Boilcr } \\
\text { Cogeneration }\end{array}$ & $\begin{array}{c}9.91 \\
0.76 \\
--\end{array}$ & $\begin{array}{c}48.1 \\
0.71 \\
=-\end{array}$ & $\begin{array}{l}5.70 \\
1.34 \\
-\end{array}$ & $\begin{array}{l}2.40 \\
0.42 \\
--\end{array}$ & $\begin{array}{c}19.0 \\
0.087 \\
--\end{array}$ & $\begin{array}{l}0.10 \\
0.0018 \\
--\end{array}$ & $\begin{array}{l}1.81 \\
--\end{array}$ & $\begin{array}{c}1.12 \\
-- \\
--\end{array}$ \\
\hline NEP, 2000 & $\begin{array}{l}\text { Process* } \\
\text { Boiler } \\
\text { Cogeneration }\end{array}$ & $\begin{array}{c}9.83 \\
0.94 \\
--\end{array}$ & $\begin{array}{c}18.5 \\
0.71 \\
--\end{array}$ & $\begin{array}{l}5.70 \\
1.88 \\
--\end{array}$ & $\begin{array}{l}2.40 \\
0.048 \\
--\end{array}$ & $\begin{array}{c}19.0 \\
0.094 \\
--\end{array}$ & $\begin{array}{l}0.10 \\
0.0013 \\
--\end{array}$ & $\begin{array}{c}0.94 \\
-- \\
--\end{array}$ & $\begin{array}{c}1.00 \\
-- \\
--\end{array}$ \\
\hline $\mathrm{SF}-2, \quad 1985$ & $\begin{array}{l}\text { Process* } \\
\text { Boiler } \\
\text { Cogeneration }\end{array}$ & $\begin{array}{l}9.91 \\
1.37 \\
--\end{array}$ & $\begin{array}{c}4 \dot{3} .1 \\
0.58 \\
--\end{array}$ & $\begin{array}{l}5.70 \\
2.36 \\
--\end{array}$ & $\begin{array}{l}2.40 \\
0.036 \\
--\end{array}$ & $\begin{array}{l}19.0 \\
0.079 \\
. \quad--.\end{array}$ & $\begin{array}{l}0.10 \\
0.0023\end{array}$ & $\begin{array}{c}1.81 \\
-- \\
--\end{array}$ & $\begin{array}{c}1.12 \\
-- \\
--\end{array}$ \\
\hline$S F-2, \quad 2000$ & $\begin{array}{l}\text { Process* } \\
\text { Boiler } \\
\text { Cogeneration }\end{array}$ & $\begin{array}{c}9.83 \\
0.73 \\
--\end{array}$ & $\begin{array}{c}18.5 \\
0.66 \\
-\end{array}$ & $\begin{array}{c}5.70 \\
1.25 \\
\therefore-\end{array}$ & $\begin{array}{l}2.40 \\
0.035 \\
--\end{array}$ & $\begin{array}{r}19.0 \\
0.078 \\
\ldots\end{array}$ & $\begin{array}{l}0.10 \\
0.0022 \\
--\end{array}$ & $\begin{array}{c}0.94 \\
-- \\
--\end{array}$ & $\begin{array}{c}1.00 \\
-- \\
--\end{array}$ \\
\hline Summary & $\begin{array}{l}\text { Base, } 1972 \\
\mathrm{~A}, 1985 \\
2000 \\
\mathrm{~B}, 1985 \\
2000 \\
\mathrm{NEP}, 1985 \\
\mathrm{SF}-2, \quad 1985\end{array}$ & $\begin{array}{c}12.0 \\
10.3 \\
9.82 \\
10.3 \\
9.82 \\
10.7 \\
10.8 \\
11.3 \\
10.6\end{array}$ & $\begin{array}{l}66.0 \\
41.5 \\
23.5 \\
41.8 \\
23.8 \\
48.8 \\
19.2 \\
48.7 \\
19.2\end{array}$ & $\begin{array}{l}8.90 \\
5.68 \\
4.50 . \\
5.78 \\
4.70 \\
7.04 \\
7.58 \\
8.06 \\
6.95\end{array}$ & $\begin{array}{l}2.40 \\
2.41 \\
2.39 \\
2.42 \\
2.39 \\
2.44 \\
2.45 \\
2.44 \\
2.44\end{array}$ & $\begin{array}{c}19.0 \\
19.4 \\
19.6 \\
19.4 \\
19.6 \\
19.1 \\
19.1 \\
19.1 \\
19.1\end{array}$ & $\begin{array}{l}0.10 \\
0.09 \\
0.07 \\
0.09 \\
0.07 \\
0.10 \\
0.10 \\
0.10 \\
0.10\end{array}$ & $\begin{array}{l}2.40 \\
1.58 \\
0.97 \\
1.58 \\
0.97 \\
1.81 \\
0.9 \\
1.8 \\
0.9\end{array}$ & $\begin{array}{l}1.2 \\
1.1 \\
1.0 \\
1.1 \\
1.0 \\
1.1 \\
1.0 \\
1.1 \\
1.0\end{array}$ \\
\hline
\end{tabular}

* Process emissions reflect scenarjo-specific mix of reduction process. Mlix is taken for 1972 as $55.2 \%$ basic oxygen process; $26.4 \%$ open hearth, and $18.4 \%$ electric arc; for 1985 as $65 \% \mathrm{BOP}, 16.6 \% \mathrm{OH}$, and $18.4 \% \mathrm{EA}$; and for 2000 as $71.9 \% \mathrm{BOP}, 9.7 \% \mathrm{OH}$, and $18.4 \% \mathrm{EA}$. 


\section{H. Cement}

The emission factors used for the cement industry are presented in Table 33, with assumptions indicated in footnotes. The key variables in calculating average emission factors for each scenario and year are the relative fractions of dry and wet production, the fuel mix to kiln and preheaters, and the phase-in rate of new environmental controls.

In meeting scenario limitations on energy intensity, shifts toward the relatively energy conserving dry process have been assumed. Specifically, Scenarios A and B go to $60 \%$ dry in 1985 and $90 \%$ dry in 2000 whereas NEP and SF-2 are maintained at the present mix of $44 \%$ dry.

Fuel mixes from Table 12 are used to calculate weighted averages for $\mathrm{SO}_{\mathrm{x}}$ emissions due to fuel combustion. New plant phase-in is from Table 23. By using weighted averages of fuel-specific emissions, wet and dry contributions, and new and base-year emission levels, the emission factors given in Table 34 are obtained.

\section{Chemicals}

The chemical industry presents the most formidable difficulty in assessing emission factors. In both the organic and inorganic sectors, a wide spectrum of sub-industries are included, with widely divergent kinds and levels of pollutants. Furthermore, since any specific sub-industry commands only a small fraction of total production, a great amount of averaging is required for generation of average emission factors for the industry as a whole.

It is thus not surprising that the Hittman emission coefficients are of questionable validity, with error estimates of perhaps $100 \%$ (ref. 5, P. II-5).

The estimation of emissions has three steps: (1) the boiler emission coefficients used by Hittman ${ }^{5}$ are subtracted from totals to obtain process 
Table 33

Emission Factors, Cement (1b/short ton)

\begin{tabular}{|c|c|c|c|c|c|c|c|}
\hline \multirow[b]{2}{*}{ Process } & & \multirow[b]{2}{*}{$\operatorname{Part}{ }^{c}$} & \multicolumn{3}{|c|}{$\mathrm{so}_{\mathrm{x}}{ }^{\mathrm{a}, \mathrm{b}}$ (kiln) } & \multirow[b]{2}{*}{${ }^{\text {No }} \times$} & \multirow[b]{2}{*}{$\operatorname{TSS}^{\mathrm{d}}$} \\
\hline & & & Gas & oil & Coal & & \\
\hline Dry: & $\begin{array}{l}1972 \text { plants } \\
\text { New plants }\end{array}$ & $\begin{array}{l}68 \\
0.4\end{array}$ & 10.2 & 12.9 & 17.8 & 2.6 & - \\
\hline Wet: & $\begin{array}{l}1972 \text { plants } \\
\text { New plants }\end{array}$ & $\begin{array}{l}52 \\
0.4\end{array}$ & 10.2 & ${ }_{n}^{13.8}$ & 20.2 & 2.6 & $\begin{array}{l}0.63 \\
0.01\end{array}$ \\
\hline
\end{tabular}

${ }^{a}$ Emissions of $10.2 \mathrm{lb} /$ short ton from mineral source included.

${ }^{b}$ Sulfur emission factors (ref. 6, p. 8.6-3) have been disaggregated for wet and dry processes by taking the energy requirement per ton output of the dry process at $75 \%$ that for the wet process.

CAssumes $80 \%$ collection efficiency for 1972 (ref. 6, p. IX-18) and EPA New Source Performance Standards for new facilities.

Cement water pollutions are due predominately to the wet process (ref. 14, p. 82). Levels for new plants are based on best available technology economically achievable (ref. 11, Water Reg. 544). In disaggregating Hit $\operatorname{tman}^{5}$ values ( $p$. IV-21, fcotnote 6330), wet process at $56 \%$ of total output was used.

Table 34

Summary Emissions: Cement (1b/short ton)

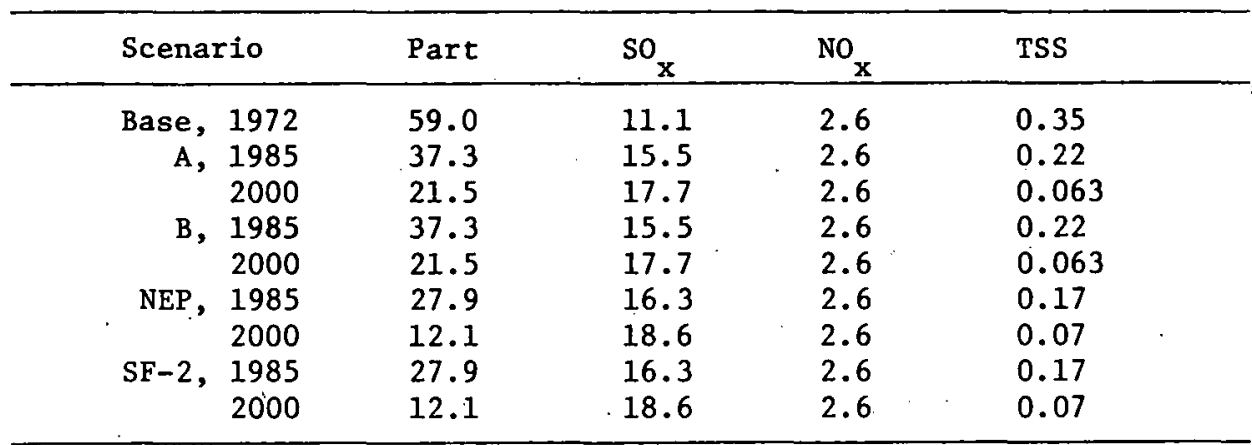


emission coefficients, (2) boiler emissions are calculated on the basis of the fuel mixes in Table 19 and the emission matrices for base-year and controlled boilers (Table 22), (3) net cogeneration contributions are calculated. Inorganic and organic industrial emissions are weighted according to the base-year tonnage breakdown of inorganic $59 \%$ and organic $41 \%$. In translating total production in quads (Table 20) into tons, proportionality between feedstock and ton output was assumed with the Hittman ${ }^{5}$ base-year value of $3.2 \times 10^{8}$ short ton/yr.

The resulting emissions for each scenario are given in Table 35 . Obtaining weighted averages of base-year and new facilities from the fractional breakdowns of Table 23 leads to the emission factors summarized at the end of Table 35 .

\section{J. Emission Coefficient Nonlinearities}

On the basis of the industry-specific emission factors developed above, one can evaluate the legitimacy. of the assumption of ten made that total emissions and total energy consumption in a given industrial sector are proportional. If, to good approximation, they are, then emission coefficients defined in terms of unit emissions per unit energy consumption can be validly used across scenarios. Total emissions (including utility emissions) by industry for a given scenario then become simple products of the emission coefficient and the energy consumed.

Emission factors thus far have been given in pounds pollutant per short ton product. Linearity implies proportionality of these emission factors with energy intensities expressed, say, in $10^{6} \mathrm{Btu} /$ short ton product. Two distinct kinds of nonlinearities need to be identified for each industry: (I) for a given scenario, emission coefficients (in $1 \mathrm{~b} / 10^{6} \mathrm{Btu}$ ) may not be constant with time; and (2) for a given year, emission coefficients may not be constant across scenarios. 
Table 35

Chemical Industry Emissions by Scenaric (1b/short ton)

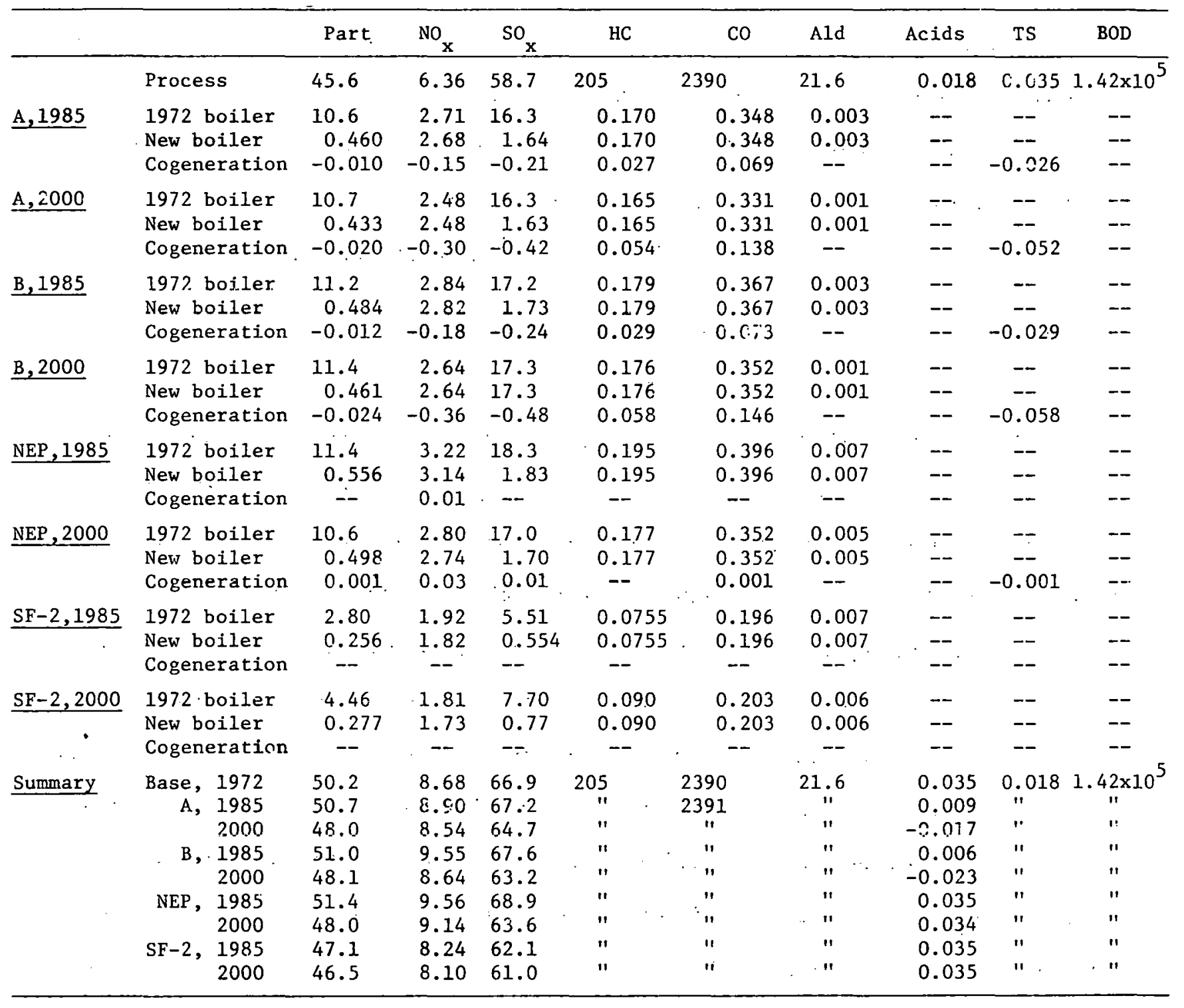


A review of the summary emission tables presented above shows the emission coefficients to vary with scenario and time. These differences should be no surprise. In phasing in new production facilities, stricter environmental controls have been assumed. Furthermore, the kinds and amounts of fuels and cogeneration are functions of the year chosen for analysis. Finally, the mix of processes employed within each industry may vary with time. On the basis of these findings, the use of scenario and time constant emission coefficients is not justified.

\section{TOTAL INDUSTRIAL EMISSIONS}

The calculation of total emissions for each scenario and year requires estimation of the contributions from industries other than the five already considered. Energy flows to "other" industries for steam boilers, direct heat, and cogeneration are given in Table 19. Since both direct heat and combustion involve the direct combustion of fuel, it is reasonable to assume the same boiler emission factors for both (ref. 5, p. IX-15). Weighted averages of direct combustion emissions are used to obtain the fractional breakdowns of Table 36, which are based on the energy demand figures for each scenario and the $2 \%$ retirement rate for base-year plants used in this study. Cogeneration emissions are calculated from Eq. (3), and the results are summarized in Table 37.

Total emissions for each scenario are reported in Table 38. The values for the five industries analyzed in detail above are obtained by multiplying the emission factors by total tonnage of production and converting units. 
Table 36

Fractional Breakdown, "Other" Industry

\begin{tabular}{|c|c|c|c|c|c|c|c|c|}
\hline & \multicolumn{2}{|c|}{$\mathbf{A}$} & \multicolumn{2}{|c|}{ B } & \multicolumn{2}{|c|}{ NEP } & \multicolumn{2}{|c|}{$\therefore \mathrm{SF}-2$} \\
\hline & 1985 & 2000 & 1985 & 2000 & 1985 & 2000 & 1985 & 2000 \\
\hline 1972 plant & 0.64 & 0.45 & 0.55 & 0.35 & 0.48 & 0.37 & 0.46 & 0.45 \\
\hline New plant & 0.36 & 0.55 & 0.45 & 0.65 & 0.52 & 0.63 & 0.54 & 0.55 \\
\hline
\end{tabular}

Table 37

Other Industrial Emission $\left(10^{6}\right.$ short ton/yr): $(d . h .=\operatorname{direct}$ heat $)$

\begin{tabular}{|c|c|c|c|c|c|c|c|c|c|}
\hline & & & Part & $\mathrm{NO}_{\mathrm{x}}$ & $\mathrm{SO}_{\mathrm{x}}$ & $\mathrm{HC}$ & $\mathrm{CO}$ & Ald & TS \\
\hline \multirow[t]{2}{*}{ A } & 1985 & $\begin{array}{c}\text { Boiler }+\mathrm{d} . \mathrm{h} . \\
\text { Cogeneration } \\
\text { Total }\end{array}$ & $\begin{array}{l}2.07 \\
0.023 \\
2.09\end{array}$ & $\begin{array}{r}1.04 \\
-0.20 \\
: 0.84\end{array}$ & $\begin{array}{c}3.41 \\
-0.094 \\
3.32\end{array}$ & $\begin{array}{l}0.057 \\
0.019 \\
0.076\end{array}$ & $\begin{array}{l}0.125 \\
0.032 \\
0.157\end{array}$ & $\begin{array}{c}.0019 \\
- \\
.0019\end{array}$ & $\begin{array}{l}-\overline{-} \\
-0.029 \\
-0.029\end{array}$ \\
\hline & 2000 & $\begin{array}{c}\text { Boiler }+d . h . \\
\text { Cogeneration } \\
\text { Total }\end{array}$ & $\begin{array}{l}2.83 \\
0.046 \\
2.88\end{array}$ & $\begin{array}{r}1.48 \\
-0.40 \\
1.08\end{array}$ & $\begin{array}{c}4.67 \\
-0.188 \\
4.48\end{array}$ & $\begin{array}{l}0.096 \\
0.038 \\
0.134\end{array}$ & $\begin{array}{l}0.193 \\
0.064 \\
0.257\end{array}$ & $\begin{array}{c}.0016 \\
.- \\
.0016\end{array}$ & $\begin{array}{l}-0.058 \\
-0.058\end{array}$ \\
\hline \multirow[t]{2}{*}{ B } & 1985 & $\begin{array}{c}\text { Boiler }+d . h \\
\text { Cogeneration } \\
\text { Total }\end{array}$ & $\begin{array}{l}2.38 \\
0.009 \\
2.39\end{array}$ & $\begin{array}{r}1.26 \\
-0.25 \\
1.01\end{array}$ & $\begin{array}{l}3.89 \\
-0.140 \\
3.75\end{array}$ & $\begin{array}{l}0.072 \\
0.018 \\
0.090\end{array}$ & $\begin{array}{l}0.156 \\
0.034 \\
0.190\end{array}$ & $\begin{array}{c}.0017 \\
.0017\end{array}$ & $\begin{array}{l}-0.031 \\
-0.031\end{array}$ \\
\hline & 2000 & $\begin{array}{c}\text { Boiler }+d . h . \\
\text { Cogeneration } \\
\text { Total }\end{array}$ & $\begin{array}{l}3.00 \\
0.018 \\
3.02\end{array}$ & $\begin{array}{r}1.93 \\
-0.50 \\
1.43\end{array}$ & $\begin{array}{l}5.06 \\
-0.280 \\
4.78\end{array}$ & $\begin{array}{l}0.126 \\
0.036 \\
0.162\end{array}$ & $\begin{array}{l}0.255 \\
0.068 \\
0.323\end{array}$ & $\begin{array}{c}.0024 \\
-- \\
.0024\end{array}$ & $\begin{array}{l}-0.062 \\
-0.062\end{array}$ \\
\hline \multirow[t]{2}{*}{ NEP } & 1985 & $\begin{array}{c}\text { Boiler }+d . h . \\
\text { Cogeneration } \\
\text { Total }\end{array}$ & $\begin{array}{l}1.47 \\
-0.010 \\
1.46\end{array}$ & $\begin{array}{c}1.19 \\
-0.069 \\
1.12\end{array}$ & $\begin{array}{c}2.78 \\
-0.043 \\
2.74\end{array}$ & $\begin{array}{l}0.061 \\
0.009 \\
0.070\end{array}$ & $\begin{array}{l}0.133 \\
0.011 \\
0.144\end{array}$ & $\begin{array}{c}.0050 \\
.- \\
.0050\end{array}$ & $\begin{array}{l}-0 \\
-0.007 \\
-0.007\end{array}$ \\
\hline & 2000 & $\begin{array}{c}\text { Boiler }+\mathrm{d} . \mathrm{h} . \\
\text { Cogeneration } \\
\text { Total }\end{array}$ & $\begin{array}{l}2.37 \\
-0.020 \\
2.35\end{array}$ & $\begin{array}{c}1.59 \\
-0.138 \\
1.45\end{array}$ & $\begin{array}{l}3.91 \\
-0.086 \\
3.82\end{array}$ & $\begin{array}{l}0.095 \\
0.018 \\
0.113\end{array}$ & $\begin{array}{l}0.204 \\
0.022 \\
0.226\end{array}$ & $\begin{array}{c}.0006 \\
-- \\
.0006\end{array}$ & $\begin{array}{c}-\overline{-} \\
-0.014 \\
-0.014\end{array}$ \\
\hline \multirow[t]{2}{*}{ SF-2 } & 21985 & $\begin{array}{c}\text { Boiler }+\mathrm{d} . \mathrm{h} . \\
\text { Cogeneration } \\
\text { Total }\end{array}$ & $\begin{array}{c}0.227 \\
-- \\
0.227\end{array}$ & $\begin{array}{l}0.93 \\
-- \\
0.93\end{array}$ & $\begin{array}{l}1.35 \\
-- \\
1.35\end{array}$ & $\begin{array}{c}0.039 \\
- \\
0.039\end{array}$ & $\begin{array}{c}0.078 \\
- \\
0.078\end{array}$ & $\begin{array}{c}.0113 \\
.- \\
.0113\end{array}$ & $\begin{array}{l}-- \\
-- \\
--\end{array}$ \\
\hline & $2000^{\circ}$ & $\begin{array}{c}\text { Boiler }+\mathrm{d} . \mathrm{h} \\
\text { Cogeneration } \\
\text { Total }\end{array}$ & $\begin{array}{l}1.85 \\
-- \\
1.85\end{array}$ & $\begin{array}{c}1.31 \\
-- \\
1.31\end{array}$ & $\begin{array}{c}3.74 \\
-- \\
3.74\end{array}$ & $\begin{array}{c}0.081 \\
0.081\end{array}$ & $\begin{array}{c}0.149 \\
- \\
0.149\end{array}$ & $\begin{array}{c}.0086 \\
.0986\end{array}$ & -- \\
\hline
\end{tabular}


Table 38

Totál Industrial Emissions (including utility credit) by scenario (10 ${ }^{\epsilon}$ short ton/yr)

\begin{tabular}{|c|c|c|c|c|c|c|c|c|c|c|c|}
\hline \multicolumn{12}{|l|}{ A 1985} \\
\hline Paper & 2.26 & 0.348 & 0.716 & 0.571 & 1.87. & 0.00523 & 0.0789 & -- & 1.15 & 1.06 & -- \\
\hline $\mathrm{A} 1$ & 0.611 & 0.0834 & 0.204 & 0.00678 & 0.0137 & 0.00015 & -- & 0.0116 & 0.0493 & 0.00068 & $\because-$ \\
\hline Fetsteel & 0.865 . & 5.49 & 0.477 & 0.202 & 1.63 & 0.00756 & -- & -- & 0.225 & -- & -- \\
\hline Cement & 1.84 & 0.128 & 0.763 & -- & - & - & -- & -- & 0.0108 & -- & -- \\
\hline Chem & 13.1 & 2.28 & 17.3 & 52.7 & 615 & 5.56 & -- & -- & 0.00235 & -- & 0.0046 \\
\hline Total & 20.77 & 7.17 & 22.8 & 53.5 & 618 & 5.57 & 0.0789 & 0.0116 & 1.32 & 1.15 & $0: 0046$ \\
\hline \multicolumn{12}{|l|}{ A 2000 . } \\
\hline Paper & 1.82 & 0.496 & 0.681 & 1.16 & 3.06 & 0.00838 & 0.0747 & -- & 0.845 & 0.910 & -- \\
\hline $\mathrm{Al}$ & 1.07 & 0.209 & 0.338 & 0.0227 & 0.0402 & -0.0000135 & -- & 0.00452 & 0.00223 & 0.00022 & -- \\
\hline Fetsteel & 1.05 & 2.50 & 0.479 & 0.255 & 2.09 & 0.00746 & -- & -- & 0.210 & -- & -- \\
\hline \multicolumn{12}{|l|}{ B 1985} \\
\hline Paper & 2.25 & 0.350 & 0.755 & 0.472 & 1.83 & $0: 00468$ & 0.0789 & - & 1.06 & 1.15 & -- \\
\hline $\mathrm{Al}$ & 0.593 & 0.0753 & 0.160 & 0.00614 & 0.013 & 0.00015 & -- & 0.0116 & 0.0493 & $0.00068^{\circ}$ & $--\cdot$ \\
\hline Fetsteal & 0.865 & 5.51 & 0.486 & 0.202 & 1.63 & 0.00756 & -- & -- & 0.225 & -- & -- \\
\hline Cement & 1.84 & 0.128 & 0.763 & - & -- & -- & $-\infty$ & -- & 0.0108 & -- & -- \\
\hline Chem & 13.2 & 2.46 & 17.4 & 52.9 & 615 & 5.56 & - & -- & 0.0015 & -- & 0.0046 \\
\hline Other & 2.39 & 1.01 & 3.75 & 0.090 & 0.190 & 0.00166 & -- & -- & -0.031 & -- & -- \\
\hline Total & 21.1 & 7.53 & 23.3 & 53.5 & 619 & 5.57 & 0.0789 & 0.0116 & 1.32 & 1.15 & 0.0046 \\
\hline \multicolumn{12}{|l|}{ B 2000} \\
\hline Paper & 1.82 & 0.525 & .0 .766 & 0.943 & 3.02 & 0.00668 & 0.0747 & -- & 0.845 & 0.910 & -- \\
\hline Paper & 2.59 & 0.446 & 1.27 & 0.437 & 1.88 & 0.00426 & 0.0791 & -- & 1.06 & 1.16 & -- \\
\hline $\mathrm{Al}$ & 0.796 & 0.127 & 0.258 & 0.00692 & 0.0153 & 0.00023 & -- & 0.0135 & 0.0742 & 0.00096 & -- \\
\hline Fetsteel & 0.770 & 3.51 & 0.507 & 0.176 & 1.38 & 0.0072 & -- & -- & 0.2095 & -- & -- \\
\hline Cement & 1.83 & 0.170 & 1.07 & -- & -- & -- & -- & -- & 0.0111 & -- & -- \\
\hline Chem & 12.1 & 2.25 & 16.2 & 48.6 & 566 & 5.11 & -- & -- & 0.00828 & -- & 0.00425 \\
\hline other & 1.46 & 1.12 & 2.74 & 0.070 & 0.144 & 0.00504 & - & -- & -0.007 & - & - \\
\hline Total & 19.5 & 7.62 & 22.0 & 49.3 & 569 & 5.13 & 0.0791 & 0.0135 & 1.36 & 1.16 & 0.00425 \\
\hline
\end{tabular}




\begin{tabular}{|c|c|c|c|c|c|c|c|c|c|c|c|}
\hline \multicolumn{12}{|c|}{ Table 38 (Continued) } \\
\hline Scenario & Part & $\mathrm{NO}_{\mathrm{x}}$ & $\mathrm{SO}_{\mathrm{x}}$ & $\mathrm{HC}$ & $\mathrm{CO}$ & Ald : & Ths & IF & $\mathrm{TS}+0 \mathrm{rg}$ & BOD & Acid \\
\hline \multicolumn{12}{|l|}{ NEP 2000} \\
\hline Paper & 2.31 & 0.763 & 1.67 & 0.738 & 3.16 & 0.00501 & $0: 0809$ & -- & 0.862 & 0.916 & -- \\
\hline $\mathrm{Al}$ & 1.30 & 0.301 & 0.470 & 0.0205 & 0.0415 & 0.00011 & -- & 0.00958 & 0.0491 & 0.00064 & - \\
\hline Fe+steel & 1.25 & 2.22 & 0.875 & 0.283 & 2.21 & 0.0116 & -- & -- & 0.2195 & -- & -- \\
\hline Cement & 1.40 & 0.302 & 2.16 & -- & -- & -- & -- & -- & 0.00812 & -- & -- \\
\hline Chem: & 20.7 & 3.95 & 27.5 & 88.6 & 1029 & 9.33 & -- & -- & 0.0147 & -- & 0.00779 \\
\hline Other & 2.35 & 1.45 & 3.82 & 0.113 & 0.226 & 0.00058 & -- & -- & -0.014 & -- & - \\
\hline Total & 29.3 & 8.99 & 36.5 & 89.8 & 1035 & 9.35 & 0.0809 & 0.20953 & 1.21 & 0.916 & 0.00779 \\
\hline \multicolumn{12}{|l|}{$\mathrm{SF}-2 \quad 1985$} \\
\hline Paper & 2.54 & 0.500 & 1.26 & 0.437 & 1.88 & 0.00458 & 0.0791 & -- & 1.06 & 1.16 & -- \\
\hline $\mathrm{Al}$ & 0.751 & 0.103 & 0.168 & 0.00491 & 0.0119 & 0.00023 & -- & 0.0167 & 0.114 & 0.00146 & -- \\
\hline Fetsteel & 0.814 & 3.51 & 0.580 & 0.176 & 1.38 & 0.0072 & -- & -- & 0.2095 & -- & -- \\
\hline Cement & 1.83 & 0.170 & 1.07 & -- & -- & - & -- & -- & 0.0111 & -- & -- \\
\hline Chem & 10.2 & 1.78 & 13.4 & 44.3 & 516 & 4.67 & -- & -- & 0.00756 & -- & 0.00389 \\
\hline other & 2.27 & 0.93 & 1.35 & 0.039 & 0.078 & 0.0113 & - & -- & -- & -- & -- \\
\hline Total & 18.4 & 6.99 & 17.8 & 45.0 & 519 & 4.69 & 0.0791 & 0.0167 & 1.40 & 1.16 & 0.00389 \\
\hline \multicolumn{12}{|l|}{$S F-2 \quad 2000$} \\
\hline Paper & 2.27 & 0.762 & 1.64 & 0.738 & 3.1 .5 & 0.00608 & 0.0809 & - & 0.862 & 0.916 & -- \\
\hline $\mathrm{Al}$ & 1.30 & 0.231 & 0.294 & 0.0133 & 0.0293 & 0.000079 & -- & 0.0214 & 0.196 & 0.00251 & -- \\
\hline Fetsteel & 1.22 & 2.22 & 0.803 & 0.282 & 2.21 & 0.0116 & -- & -- & 0.220 & -- & -- \\
\hline Cement & 1.40 & 0.302 & 2.16 & -- & $\dot{-i}$ & $\cdot--$ & -- & -- & 0.00812 & -- & -- \\
\hline Chem & 19.1 & 3.33 & 25.1 & 84.4 & 984 & 8.89 & -- & -- & 0.014 & -- & 0.00721 \\
\hline Other & 1.85 & 1.31 & 3.74 & 0.081 & 0.149 & 0.00856 & -- & -- & -- & -- & -- \\
\hline Total & 27.1 & 8.16 & 34.0 & 85.5 & 990 & 8.92: & 0.0809 & $0.0214^{\circ}$ & 1.30 & 0.918 & 0.00721 \\
\hline
\end{tabular}




\section{CONCLUSIONS}

In this study the environmental impacts of conservation in the industrial sector have been analyzed. For the four selected scenarios and two target years, energy allotments and production levels implied by each scenario have been evaluated. Technological changes required to achieve associated energy efficiencies have been designated. Emission.factors for a range of pollutants have been estimated for five industries,.. incorporating scenario-specific fuel and process mixes, environmental control technology penetration, and cogeneration impact.

The Hittman report, ${ }^{5}$ while providing a wealth of base-year data, is inadequate for environmental impact analysis by scenario. First, many of the base-year emission factors had to be updated to reflect revised fuel mixes by industry and more precise data on emission control levels, and process-related emissions had to be disaggregated. Revisions of the base-year industrial data base would be useful subsequent work. Second, since emission coefficients are functions of cogeneration and emission control technology penetration, fuel mix, and process shift, they depend on scenario and year. Accurate assessment of industrial environmental impact entails the development of scenario-specific coefficients which are functions of target year.

The Reisman and Goldberg study ${ }^{7}$ also requires substantial revisions for adequate indication of base-year fuel-specific environmental emission coefficients. The methodology, based on Hittman fuel mixes and the EPA boiler emission matrix, is approximate. A more accurate analysis, as discussed throughout this report, would utilize revised fuel mixes and, instead of tracing all emissions to steam boilers, would employ weighted averages over process mixes for each industry. 
Various values for base-year emissions are compared in Table 39.

Further refinement of the present study would thus require more adequate base-year emissions data, more detailed analysis of the degree and pace of implementation of control technologies, and better estimates (perhaps through surveys) of the environmental effects of new process technologies.

Table 39

Base-Year Total Emissions Uśed in Three Studies

\begin{tabular}{|c|c|c|c|c|c|c|c|c|c|c|c|c|}
\hline & \multicolumn{3}{|c|}{ Paper } & \multicolumn{3}{|c|}{ Aluminum } & \multicolumn{2}{|c|}{ Iron and } & \multirow{2}{*}{$\frac{\text { Steel* }}{\mathrm{SO}_{\mathrm{x}}}$} & \multicolumn{3}{|c|}{ Cement } \\
\hline & Part & ${ }^{N} O_{x}$ & $\mathrm{SO}_{\mathbf{x}}$ & Part & $\mathrm{NO}_{\mathrm{x}}$ & ${ }^{\mathrm{SO}} \times$ & Part & $\mathrm{NO}_{x}$ & & Part & ${ }^{\text {NO }} x$ & $\mathrm{SO}_{\mathbf{x}}$ \\
\hline $\begin{array}{l}\text { Present } \\
\text { study }\end{array}$ & 96.2 & 9.14 & 31.8 & 150 & 15.9 & 13.3 & 12.0 & 66.0 & 8.90 & 59.0 & 2.6 & 11.1 \\
\hline Hittman ${ }^{a}$ & 90.6 & 11.3 & 33.0 & 252 & N.A. & N.A. & 21.9 & 90.8 & 6.5 & 98.2 & 0.20 & .620 \\
\hline $\begin{array}{l}\text { Reisman } \\
\text { and } \\
\text { Goldberg }\end{array}$ & 17.6 & 7.0 & 26.2 & 14.3 & 16.8 & 25.6 & 42.6 & 8.38 & 23.4 & 2.94 & 1.25 & 4.58 \\
\hline
\end{tabular}

*Coking included

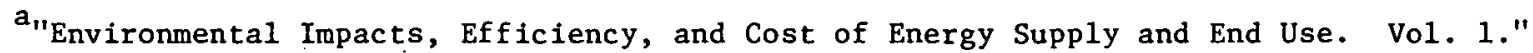
Hittman Associates, Inc., November 1974.

b"Fuel Specific Environmental Emission Coefficients for -Industrial Processes." A.W. Reisman and M.D. Goldberg, BNL 50s11, January 1976. 


\section{REFERENCES}

1. Outlook for Energy Demand and Conservation (draft), CONAES Panel on Demand and Conservation, Dec. 1976.

2. D.J. Behling Jr., Analysis of Past and Expected Future Trends in U.S. Energy Consumption, 1947-2000, BNL 50725, Feb. 1977.

3. R. Rosen and A. Doernberg, Memo to K.C. Hoffman, BNL, June 2, 1977.

4. A Study of Improved Fue1 Effectiveness in the Iron and Steel and Paper and Pulp Industries, March 1976.

5. Environmenta1 Impacts, Efficiency, and Cost of Energy Supply and End Use, Vol. 1, Hittman Associates Inc., Nov. 1974.

6. Compilation of Air Pollution Emission Factors, 2nd ed., EPA,* Feb. 1976.

7. A.W. Reisman and M.D. Goldberg, Fuel-Specific Environmental Emission Coefficients for Industrial Processes, BNL 50511, Jan. 1976.

8. R. Stern et al., Environmental Residuals for Use in the Evaluation of State Energy Conservation Programs, Informal Rep. BNL 22499, March 1977.

9. Standards of performance for new stationary sources, EPA, Federal Register, Dec. 1971.

10. Standards of performance for new stationary sources: kraft pulp mills, EPA, Federal Register, Sept. 1976.

11. Environmental Regulation Handbook, Environmental Information Center, 1977.

12. Air Pollution Control in the Primary Aluminum Industry, EPA, 1973.

13. Energy Requirements for Air Pollution Control in the Primary Aluminum Industry, U.S. Dept. of Commerce, Jan. 1977.

14. Environmental Consideration of Selected Energy Conserving Manufacturing Options, Vo1. 2, EPA, June 1976.

$\star_{\mathrm{EPA}}=$ U.S. Environmental Protection Agency. 


\section{THIS PAGE \\ WAS INTENTIONALLY \\ LEFT BLANK}


APPEND.IX. INDUSTRIAL ENERGY FLOW DIAGRAMS 


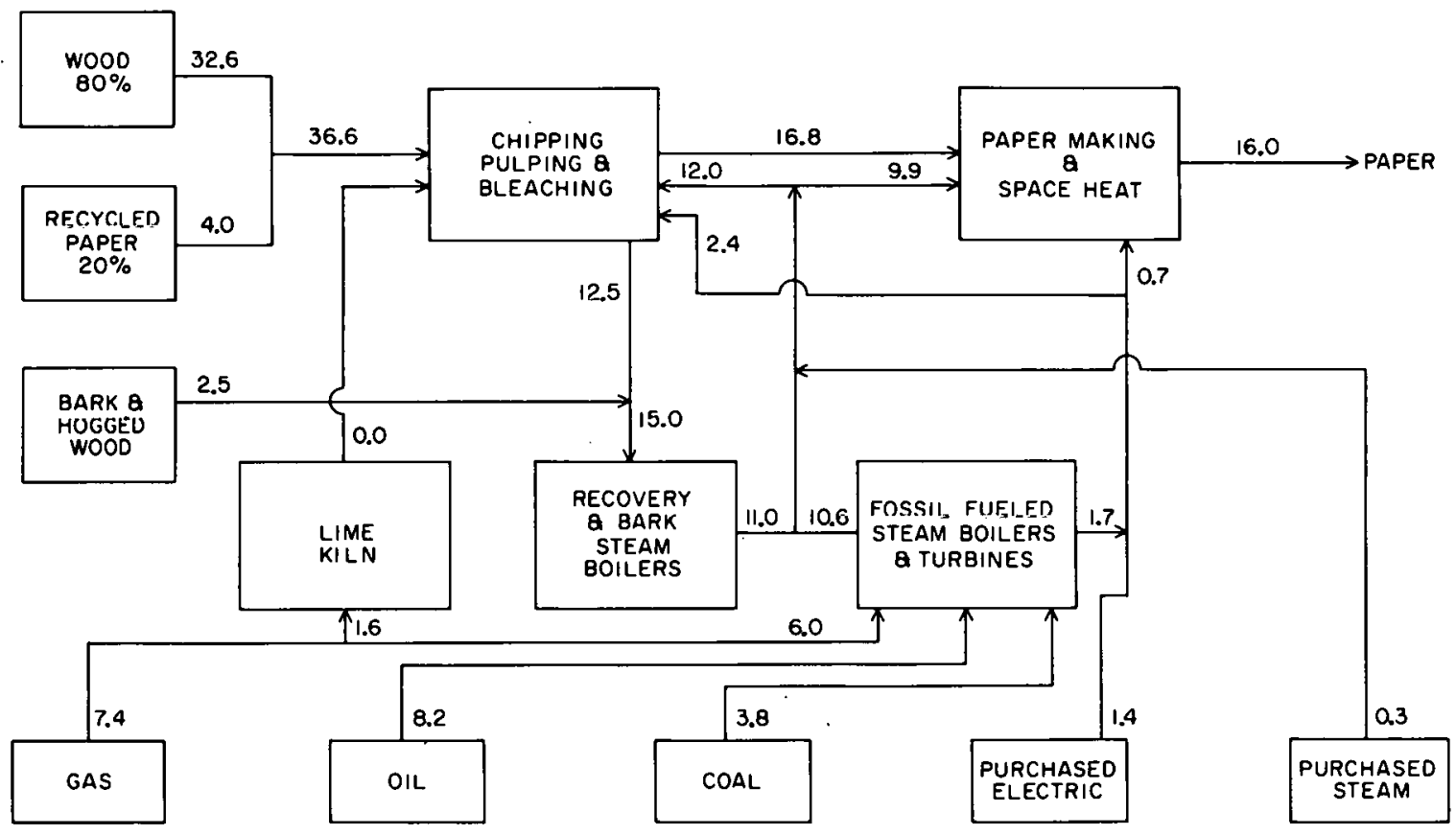

TOTAL PURCHASED ENERGY $=21.1 \times 10^{6} \mathrm{Btu} / \mathrm{TON}$ OTHER ENERGY $=23.1 \times 10^{6} \mathrm{Btu} / \mathrm{TON}$ TOTAL NET ENERGY $=44.2 \times 10^{6} \mathrm{Btu} /$ TON TOTAL PRODUCTION $=59.5 \times 10^{6}$ TONS

Figure A-1. Paper industry - R.E.S. extension - 1972. (Energy flows in units of $10^{6} \mathrm{Btu} /$ ton of product.) 


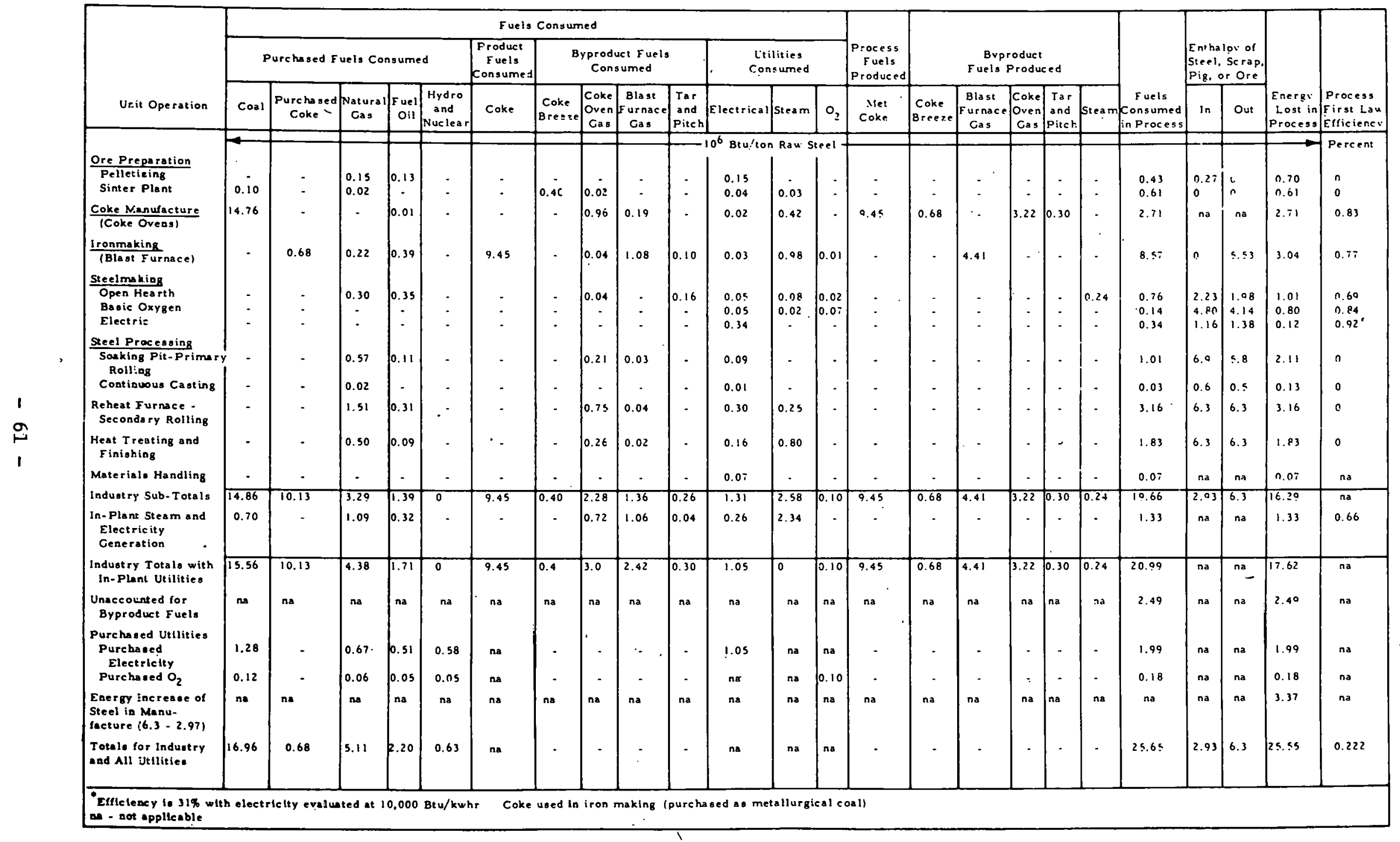

Figure A-2. Energy balance for steel industry, 1973. 
TOTAL DOMESTIC PRODUCTION $=8.13 \times 10^{7}$ TONS/0.53 QUADS NET ENERGY

0.61 QUADS GROSS ENERGY

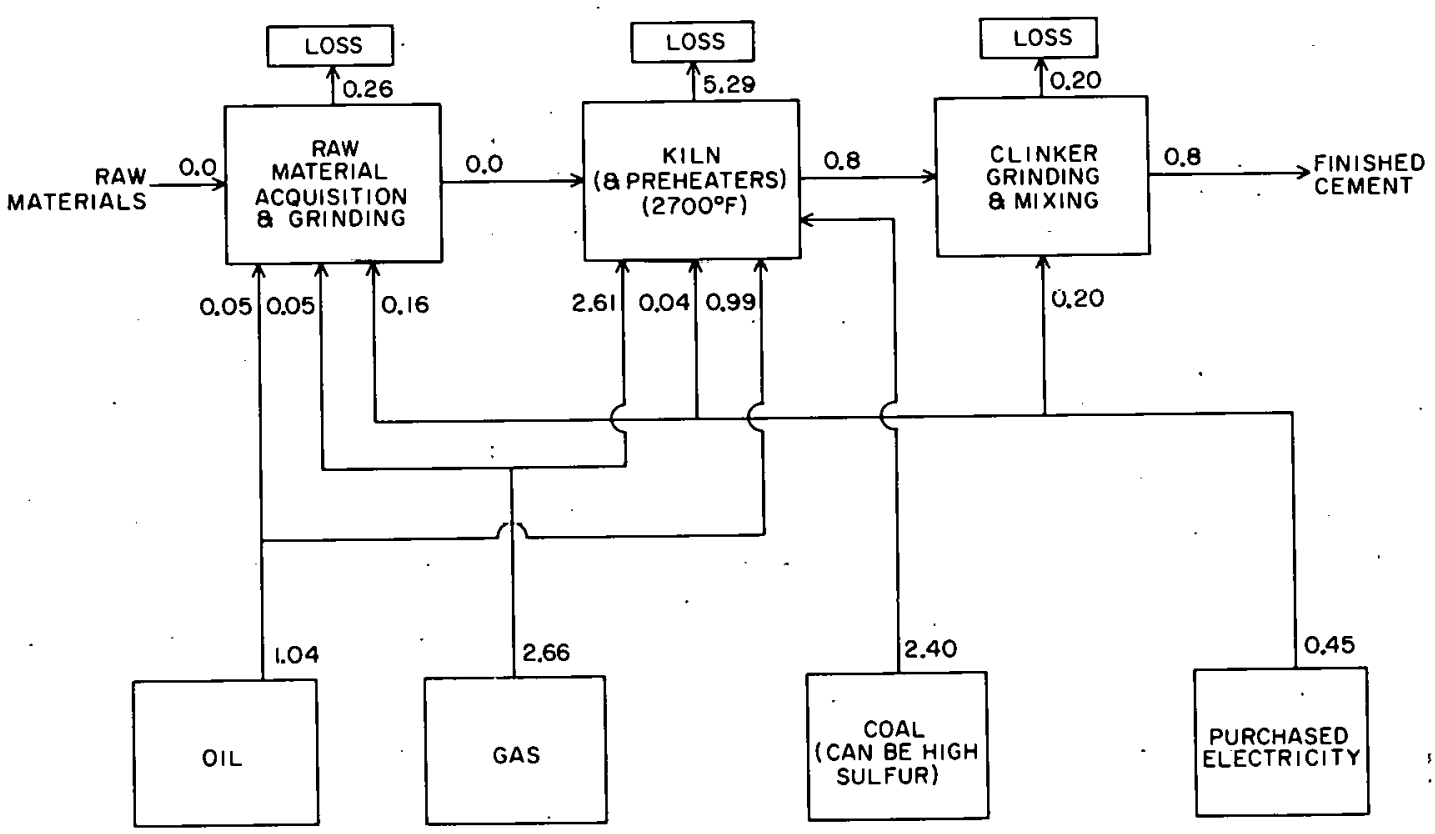

NET TOTAL ENERGY $=6.55 \times 10^{6}$ Btu $/$ TON $/$ GROSS $=7.45 \times 10^{6}$

Figure A-3. Cement industry, 1973. (Energy flows in units of $\left.10^{6} \mathrm{Btu} / \mathrm{ton}.\right)$ 


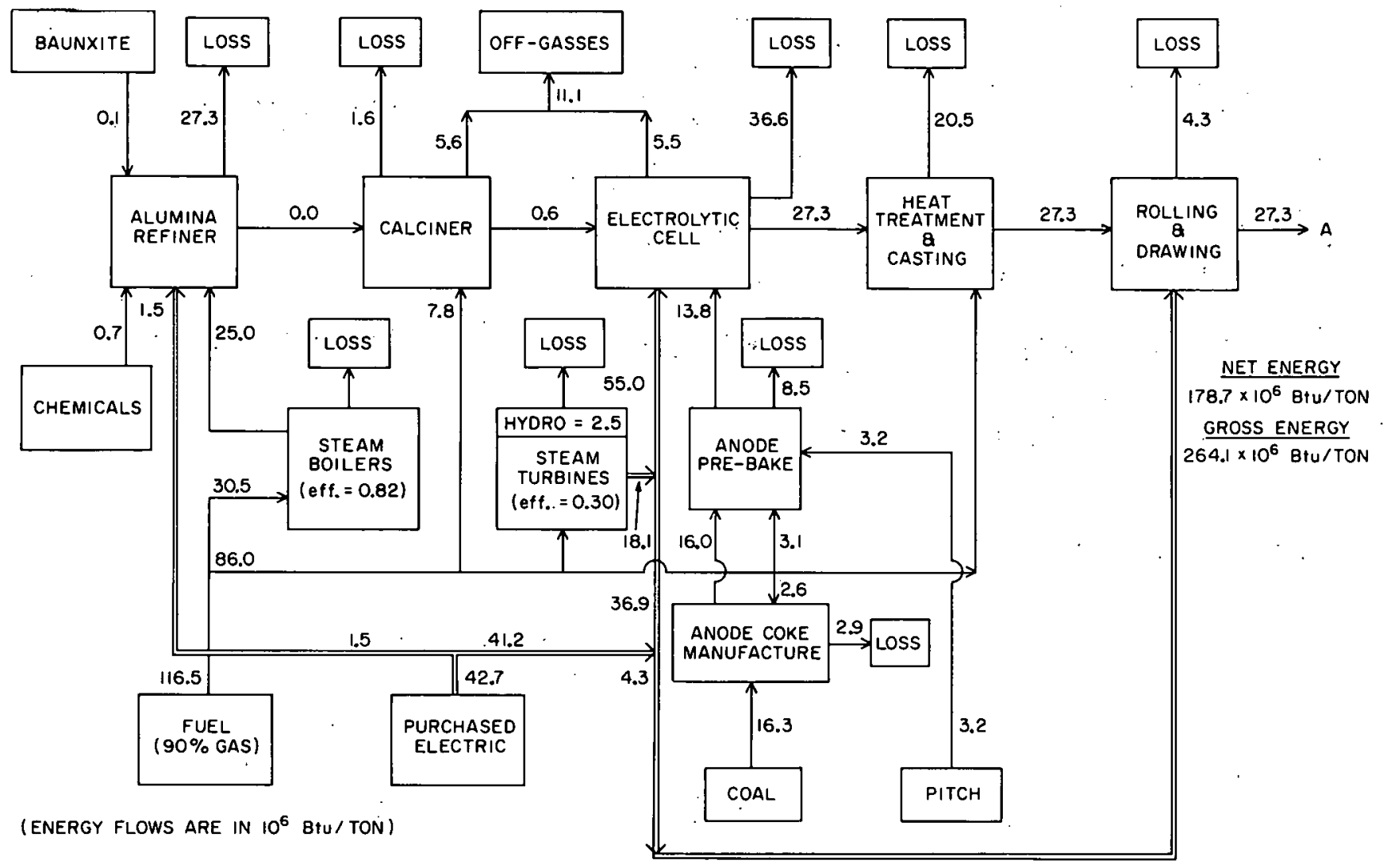

Figure A-4. Primary aluminum production, 1972.

$4.1 \times 10^{6}$ tons. 


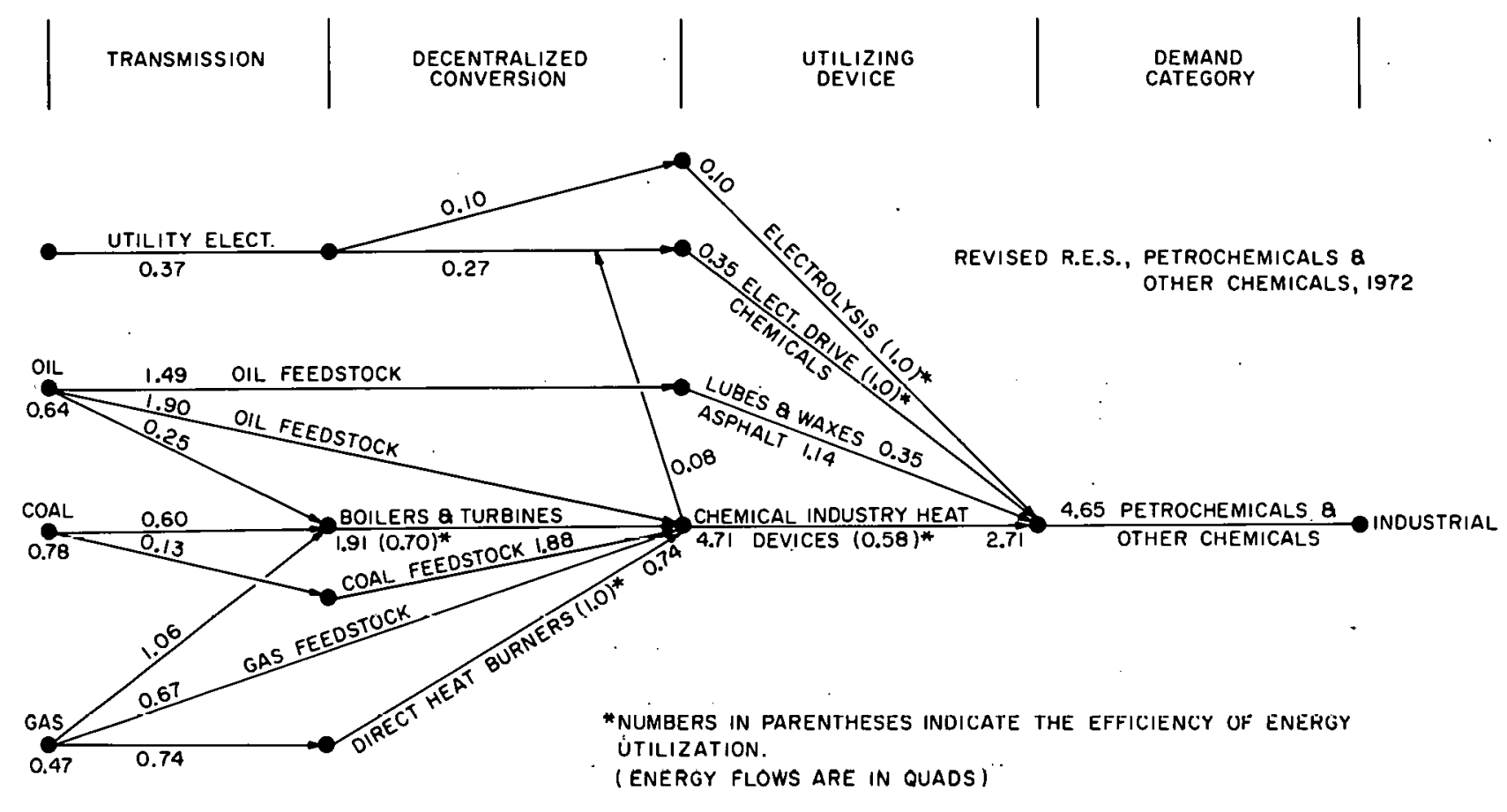

Figure A-5. Revised R.E.S., petrochemicals and other chemicals, 1972.

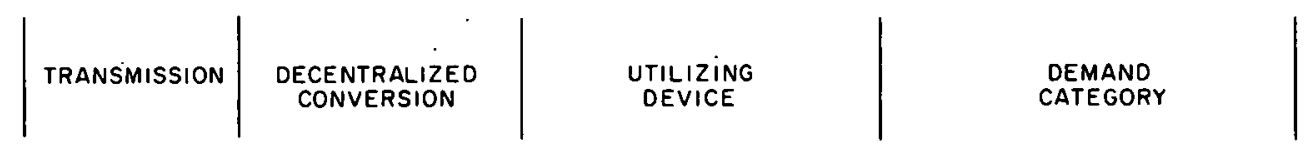

REVISED R.E.S., CEMENT, 1973

$8.13 \times 10^{7}$ TONS

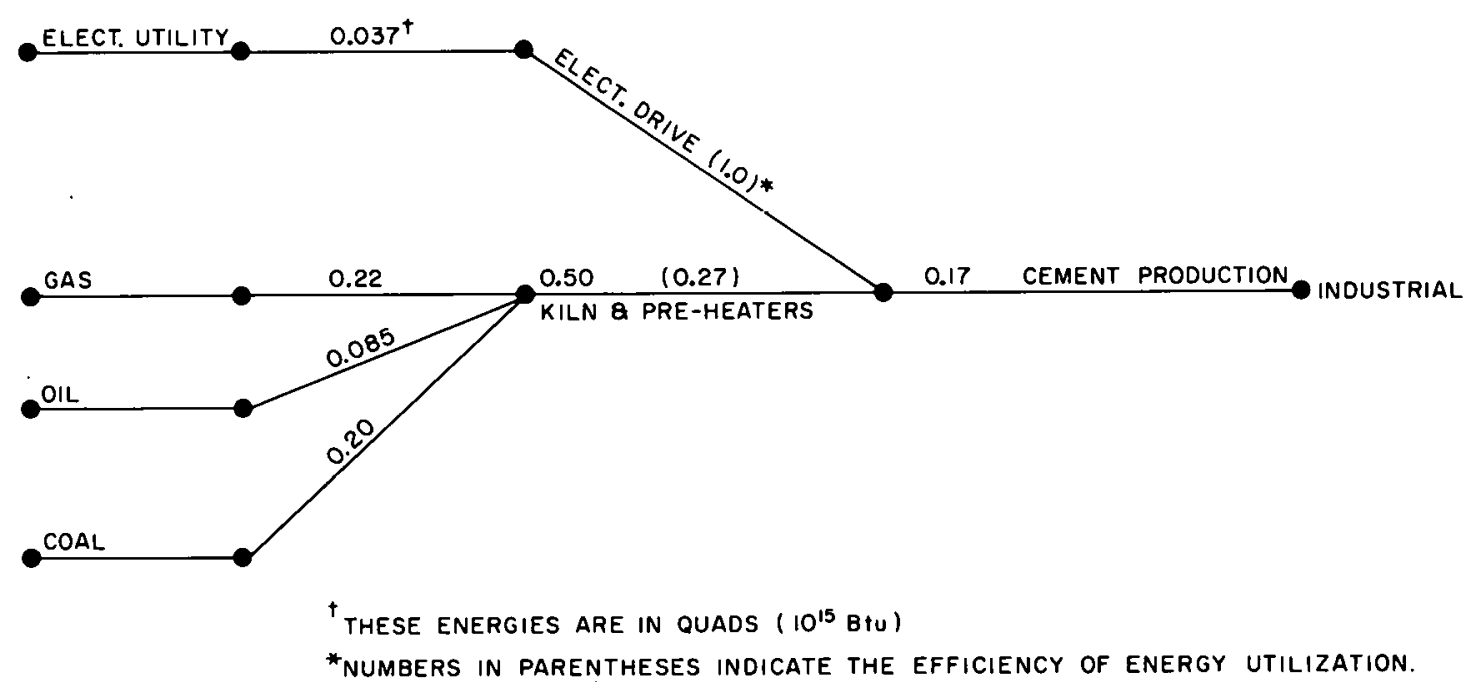

Figure A-6. Revised R.E.S., cement, 1973.

$8.13 \times 10^{7}$ tons. 

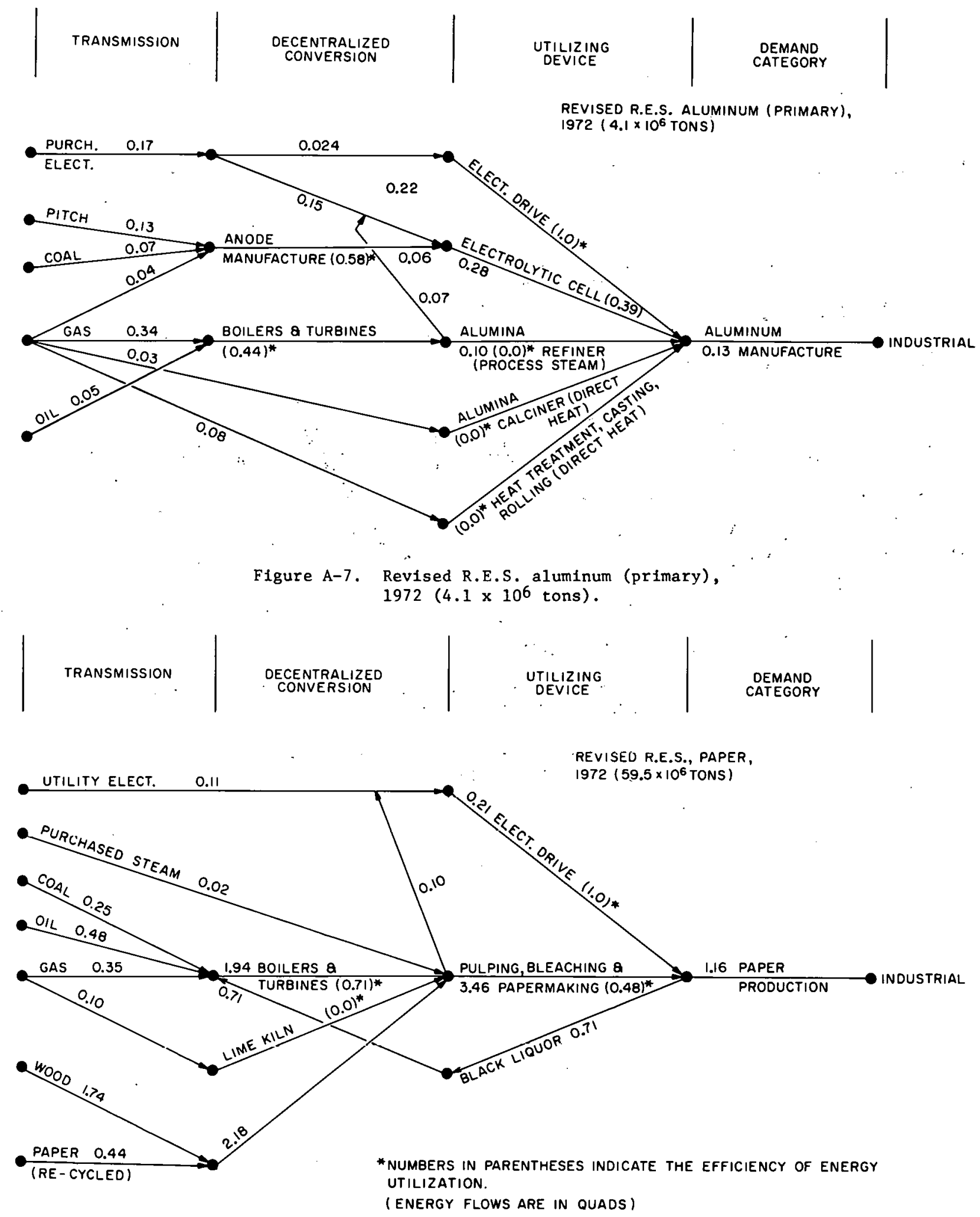

Figure A-8. Revised R.E.S., paper, 1972 (59.5 × $10^{6}$ tons). 

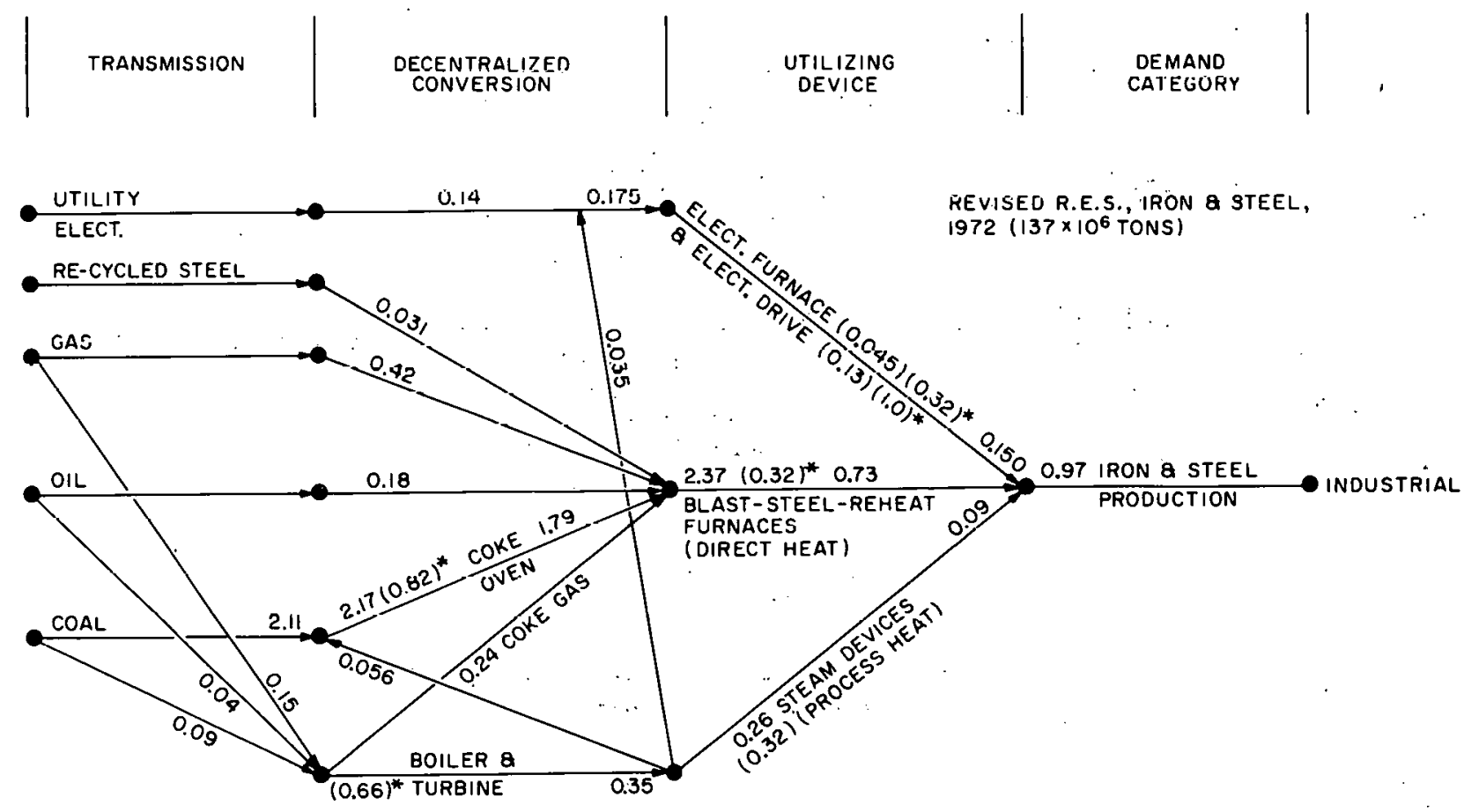

* NUMBERS IN PARENTHESES INDICATE THE EFFICIENCY OF ENERGy UTILIZATION. (ENERGY FLOWS ARE IN QUADS)

Figure A-9. Revised R.E.S., iron and steel, 1972 (137 × $10^{6}$ tons). 